Geosci. Model Dev. Discuss., https://doi.org/10.5194/gmd-2018-8

Manuscript under review for journal Geosci. Model Dev.

Discussion started: 24 January 2018

(c) Author(s) 2018. CC BY 4.0 License.

\title{
Development of the city-scale chemistry transport model CityChem-EPISODE and its application to the city of Hamburg
}

\author{
Matthias $\operatorname{Karl}^{1}$ \\ ${ }^{1}$ Chemistry Transport Modelling, Helmholtz-Zentrum Geesthacht, Geesthacht, Germany \\ Correspondence to: Matthias Karl (matthias.karl@hzg.de)
}

\begin{abstract}
This paper describes the City-scale Chemistry (CityChem) extension of the urban dispersion model EPISODE with the aim to enable chemistry/transport simulations of multiple reactive pollutants on urban scales. The new model is called CityChem-EPISODE. The primary focus is on the simulation of urban ozone concentrations. Ozone is produced in photochemical reaction cycles involving nitrogen oxides $\left(\mathrm{NO}_{\mathrm{X}}\right)$ and volatile organic compounds (VOC) emitted by various anthropogenic activities in the urban area. The performance of the new model was evaluated with a series of synthetic tests and with a first application to the air quality situation in the city of Hamburg, Germany. The model performs fairly well for ozone in terms of temporal correlation and bias at the air quality monitoring stations in Hamburg. In summer afternoons, when photochemical activity is highest, modelled median ozone at an inner-city urban background station was about $30 \%$ lower than the observed median ozone. Inaccuracy of the computed photolysis frequency of nitrogen dioxide $\left(\mathrm{NO}_{2}\right)$ is the most probable explanation for this. CityChem-EPISODE reproduces the spatial variation of annual mean $\mathrm{NO}_{2}$ concentrations between urban background, traffic and industrial stations. However, the temporal correlation between modelled and observed hourly $\mathrm{NO}_{2}$ concentrations is weak for some of the stations. For daily mean $\mathrm{PM}_{10}$, the performance of CityChem-EPISODE is moderate due to low temporal correlation. The low correlation is linked to uncertainties in the seasonal cycle of the anthropogenic particulate matter (PM) emissions within the urban area. Missing emissions from domestic heating might be an explanation for the too low modelled $\mathrm{PM}_{10}$ in winter months. Four areas of need for improvement have been identified: (1) dry and wet deposition fluxes; (2) treatment of photochemistry in the urban atmosphere; (3) formation of secondary inorganic aerosol (SIA); and (4) formation of biogenic and anthropogenic secondary organic aerosol (SOA). The inclusion of secondary aerosol formation will allow for a better sectorial attribution of observed PM levels. Envisaged applications of the CityChem-EPISODE model are urban air quality studies, environmental impact assessment, sensitivity analysis of sector-specific emission and the assessment of local and regional emission abatement policy options.
\end{abstract}

\section{Introduction}

Urban air pollution is a major concern for most cities of the world, in developed and developing countries, causing a multitude of adverse effects on human health, ecosystems, the built environment and climate (Molina and Molina, 2004; Pascal et al., 2013; Baklanov et al., 2016). The major source of urban air pollution is the road transport sector, but also domestic, commercial, and industrial activities are contributing. In addition, cities are affected by the short-range and long-range transport 
Geosci. Model Dev. Discuss., https://doi.org/10.5194/gmd-2018-8

Manuscript under review for journal Geosci. Model Dev.

Discussion started: 24 January 2018

(c) Author(s) 2018. CC BY 4.0 License.

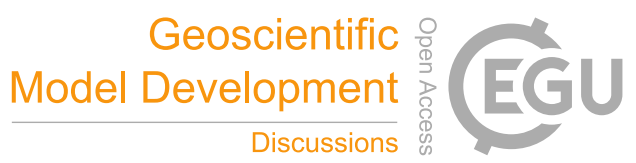

(c) (i)

of gaseous and particulate pollutants from the surrounding region; especially pollution levels of fine particulate matter in the urban background were shown to be largely controlled by the atmospheric transport from up-wind regions (Beekmann et al., 2015). Air quality modelling plays an important role by assessing the air pollution situation in urban areas and by supporting the development of guidelines for efficient air quality planning, as highlighted in the current Air Quality Directive (AQD) of

5 the European Commission (EC, 2008).

Main air pollution issues in Europe are the human health impacts of exposure to particulate matter (PM) and ozone $\left(\mathrm{O}_{3}\right)$; while the effects of air pollution due to nitrogen dioxide $\left(\mathrm{NO}_{2}\right)$, sulphur dioxide $\left(\mathrm{SO}_{2}\right)$, carbon monoxide $(\mathrm{CO})$, lead $(\mathrm{Pb})$ and benzene have been reduced during the last two decades due to emission abatement measures. In 2013, about $15 \%$ of the population living in urban areas was exposed to ozone concentrations above the European Union (EU) target value (EEA, 2015). Ozone is formed in the atmosphere in photochemical reaction cycles, bringing the emission of ozone precursors, i.e. nitrogen oxides $\left(\mathrm{NO}_{\mathrm{X}}=\mathrm{NO}_{2}+\mathrm{NO}\right.$ ), and volatile organic compounds (VOCs) and their gas-phase atmospheric chemistry into the focus of air quality modelling. However, most current urban dispersion models treat air pollutants as passive tracer substances or use highly parameterized schemes for photochemistry (Owen et al., 2000), when simulating the spatio-temporal distribution and variation of air pollutant concentrations on the city-scale.

15 A review of local and regional air quality plans revealed that a majority of sampled cases applies more than one model in the air quality planning (Thunis et al., 2016). This demonstrates that at present no single model is capable to describe properly all relevant spatial scales of the air pollution phenomena (Thunis et al., 2016). Eulerian chemistry-transport model (CTM) systems using numerical methods for solving photochemistry (including chemical reaction schemes with varying degree of detail) have mainly been used for regional-scale air quality studies. Recent nested model approaches using regional CTM systems have been applied to capture pollution processes from the continental scale to the local scale, using between 1- $\mathrm{km}$ to 5 - $\mathrm{km}$ resolution and a temporal resolution of 1 hour for the innermost domain (e.g. Borge et al., 2014; Karl et al., 2015; Petetin et al., 2015; Valverde et al., 2016), yet not resolving the details in the emission processing and near-field dispersion at the street and neighbourhood level.

The City-scale Chemistry (CityChem) model is an extension of the urban dispersion model EPISODE (Slørdal et al., 2003, 2008) having the capability of modelling the photochemical transformation of multiple pollutants along with atmospheric diffusion to produce pollutant concentration fields for the entire city on a horizontal resolution of $100 \mathrm{~m}$ or even finer. The new model is called the CityChem-EPISODE model. The CityChem-EPISODE and the EPISODE models are open source code subject to the Reciprocal Public License (RPL) version 1.5 (https://opensource.org/licenses/RPL-1.5). EPISODE is an Eulerian dispersion model developed at the Norwegian Institute for Air Research (NILU) appropriate for air quality studies at the local scale. The EPISODE model is an integral part of the operational Air Quality Information System AirQUIS 2006 (Slørdal et al., 2008). Validation studies for the EPISODE dispersion model have shown good correspondence between modelled and measured concentrations of $\mathrm{NO}_{2}, \mathrm{PM}_{10}$, and $\mathrm{PM}_{2.5}$ in the urban areas of Oslo (Oftedal et al., 2009) and Trondheim (Laupsa and Slørdal, 2003; Slørdal et al., 2006) in Norway.

CityChem-EPISODE has been designed for the three-dimensional (3-D) dispersion of reactive pollutants by representing their dispersion and chemical transformation in the urban atmosphere from local-scale to the meso-scale, extending verti- 
Geosci. Model Dev. Discuss., https://doi.org/10.5194/gmd-2018-8

Manuscript under review for journal Geosci. Model Dev.

Discussion started: 24 January 2018

(c) Author(s) 2018. CC BY 4.0 License.

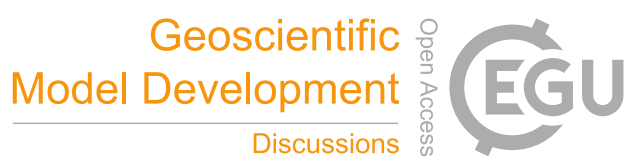

(c) (i)

cally up to $4000 \mathrm{~m}$ height and horizontally from a few kilometres up to about $100 \mathrm{~km}$. Its purpose is to fill the gap between regional-scale air quality simulations with CTM systems on one side and micro-scale simulations of limited areas of the urban environment using large eddy simulation (LES) techniques (Nieuwstadt and Meeder, 1997; Kikumoto and Ooka, 2012), on the other side. In order to resolve pollutant dispersion in proximity of emission source objects (point source and lines sources),

5 CityChem-EPISODE systematically combines the 3-D Eulerian grid model with sub-grid Gaussian dispersion models, allowing computation of pollutant concentrations near road traffic line sources and industrial point sources with high spatial resolution. The chemical transformation of pollutants is considered in great detail within the Eulerian grid and in a simplified manner for the sub-grid dispersion.

This paper provides a general description of the model structure and a technical description of the physics and chemistry implemented in the CityChem-EPISODE model. In particular, the implemented features that distinguish the model from typical dispersion models applied for the simulation of urban air quality are described. The performance of the model is evaluated by: (1) a set of synthetic tests to study the basic functionalities and physical options of the model; and (2) a first model application for predicting the air quality in the city of Hamburg, Germany. In Sect. 2, the components of the model with a focus on the treatment of chemical reactions and the treatment of dispersion near line sources is given. A series of tests assessing the model performance with respect to applied boundary conditions, vertical mixing, photochemical processing and near-field dispersion are presented in Sect. 3. Results from a one-year model simulation for the air quality of Hamburg are discussed and compared against observation data from the city's air quality monitoring network in Sect. 4. Sect. 5 gives an overview the planned improvements for the coming versions of the model.

\section{Description of the CityChem-EPISODE model components}

CityChem-EPISODE runs on Linux computers in single processor mode. CityChem-EPISODE provides concentration output and other diagnostic output in form of netCDF files, enabling quick conversion into Geographic Information System (GIS) shape files. The model reads meteorological fields generated by the prognostic meteorology component of the Australian air quality model TAPM (The Air Pollution Model; Hurley, 2008; Hurley et al., 2005). If the TAPM model is not available, the utility MCWIND is provided to produce a diagnostic wind flow field based on meteorological observations. The dispersion parameters, vertical profile functions in the surface layer, and the eddy diffusivities are then calculated internally in CityChemEPISODE in combination with the meteorological data extracted from TAPM or MCWIND, following the methods of van Ulden and Holtslag (1985), Bøhler (1996), and Slørdal et al. (2003), based on Monin-Obukhov similarity theory. The height of the planetary boundary layer (PBL), i.e. mixing height, as well as turbulent surface fluxes are taken directly from TAPM. Although this procedure introduces a slight inconsistency, it is expected that the treatment will be more realistic due to the advanced physics applied in TAPM. In the case of MCWIND, PBL height is estimated using the methods of Nieuwstadt (1981), Seibert et al. (2000) and Batchvarova and Gryning (1991).

The following features, which are not part of the operational EPISODE model (Slørdal et al., 2003, 2008), have been implemented in CityChem-EPISODE: 
Geosci. Model Dev. Discuss., https://doi.org/10.5194/gmd-2018-8

Manuscript under review for journal Geosci. Model Dev.

Discussion started: 24 January 2018

(c) Author(s) 2018. CC BY 4.0 License.

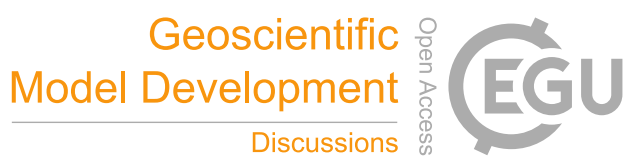

(c) $\underset{\mathrm{BY}}{\mathrm{B}}$

1. Reading and using time-varying (hourly) 3-D concentrations of compounds at the lateral and vertical boundaries from the Community Multiscale Air Quality (CMAQ; Byun and Schere, 2006) model as initial and boundary concentrations. Thus CityChem-EPISODE can be used as part of a nested model chain from continental to local scales.

2. Calculating time-dependent concentrations of air pollutants on a 3-D Eulerian grid (short: main grid) with coarse resolution $\left(\leq 1 \times 1 \mathrm{~km}^{2}\right)$ and simultaneously local ground air concentrations with high resolution $\left(100 \times 100 \mathrm{~m}^{2}\right)$ as well as in selected locations (monitoring stations). Full consistency has been achieved between the main grid (Eulerian) concentration field and the surface receptor concentration field; generating model output of both fields.

3. Solving photochemistry for multiple air pollutants by activation of the numerical chemistry solver for the main grid concentrations. A simplified version of the default EMEP chemistry mechanism ("EmChem09"; Simpson et al., 2012) is used which can be extended as needed by a modified GenChem (EMEP) chemical pre-processor.

4. A new option for the vertical eddy diffusivity that takes into account a baseline turbulent mixing due to the anthropogenic heating effect in cities.

5. Modifications to the plume rise from elevated point sources as outlined in Karl et al. (2014) for an improved calculation of the wind speed at the plume height.

6. Modifications of the line source emission model to compute receptor point concentrations in street canyons.

7. Possibility to calculate particle number concentrations in three size classes according to the parameterisation given by Karl et al. (2016).

Depending on the chosen chemistry options, CityChem-EPISODE can be run either as a tracer model or as a chemistry model. Running as tracer model implies that all air pollutants are only dispersed as (chemically inert) passive tracers, whereas running as chemistry model implies chemical transformation driven by photo-oxidation using either a detailed atmospheric chemistry mechanism or simple photo-stationary steady-state. CityChem-EPISODE is in particular useful for studies on formation of ozone and aerosols in urban areas. In the current version, aerosol particles can be treated in terms of primary emitted $\mathrm{PM}$ and/or of total particle number (PN). Particulate matter is separated in $\mathrm{PM}_{2.5}$ (PM with aerodynamic diameter $\leq 2.5 \mu \mathrm{m}$ ) and $\mathrm{PM}_{10}$ (PM with aerodynamic diameter $\left.\leq 10 \mu \mathrm{m}\right)$. Secondary particle formation is not implemented in the model until now; this is planned for the next version.

Figure 1 provides an overview of the components of the CityChem-EPISODE model system. In the next sections, the model components of CityChem-EPISODE and the interfaces and utilities that come along with the model are described. Sect. 2.1 describes the terms of the advection/-diffusion equation, as well as the treatment of photochemistry and deposition on the Eulerian 3-D grid. CityChem-EPISODE considers three categories of emissions: area source emissions, line source emissions and point source emissions. Sect. 2.2 describes the embedded Gaussian sub-grid models for point emission sources (SEGPLU) and line emission sources (HIWAY-2 and SSCM). Sect. 2.3 describes in more detail the interactions between the Eulerian 3-D grid and the receptor sampling grid and how the mass-balance is maintained between the two model grids. Sect. 2.4 describes 
Geosci. Model Dev. Discuss., https://doi.org/10.5194/gmd-2018-8

Manuscript under review for journal Geosci. Model Dev.

Discussion started: 24 January 2018

(c) Author(s) 2018. CC BY 4.0 License.

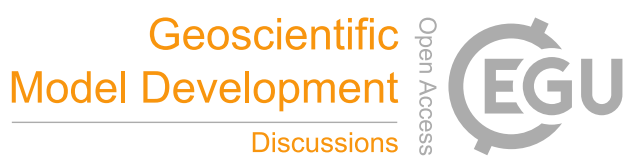

(c) (i)

the pre-processing utilities for input preparation. For convenience, the CityChem-EPISODE is referred to as CityChem model for the remainder of the paper.

\subsection{Description of the Eulerian grid model component}

The CityChem model simulates the emission, dispersion, chemical reaction, and removal of pollutants in the urban atmosphere

5 by integrating forward in time and solves the advection/-diffusion equation for each chemical species on a 3-D Eulerian grid. Vertically, a terrain-following sigma-coordinate system is applied, defined from an idealised hydrostatic pressure-distribution. The derivation of the sigma-coordinate transform of the advection/-diffusion equation is described in Slørdal et al. (2003). The terms describing the turbulent diffusion are represented according to the mixing length theory (K-theory). K-theory is only applicable as long as the reaction processes are slow compared with the turbulent transport, and the characteristic length scales and time scales for changes in the mean concentration field are large compared with the corresponding scales for turbulent transport (Seinfeld and Pandis, 2006). The validity of the K-theory limits the refinement of the grid resolution of the Eulerian main grid that can be employed in CityChem. The sub-grid variability close to the emission sources due the fast photochemistry between $\mathrm{O}_{3}$, nitrogen oxide $(\mathrm{NO})$ and nitrogen dioxide $\left(\mathrm{NO}_{2}\right)$ is therefore approximated with the photo-stationary equilibrium, applied in the Gaussian sub-grid models.

The numerical solution employs operator splitting to separately solve the processes: (1) advection; (2) diffusion; (3) chemical reaction and (4) deposition. The numerical model time step of the CityChem model is calculated dynamically based on the critical time steps associated with the solution of the horizontal advection and vertical advection and diffusion processes. The time step is also adjusted slightly downward to ensure that nsteps $=3600(\mathrm{~s}) / d t$ is always an integer value. This way, all operations are performed at an even number of times so that every other operator sequence may be a mirror in the opposite direction of the first sequence to reduce time-splitting errors.

The model user can choose from numerical schemes with varying degree of accuracy for solving the advection/-diffusion processes. Table 1 gives an overview of the available options for numerical schemes for solution of the advection, diffusion and chemistry terms. All numerical schemes and algorithms for advection and diffusion are also part of the operational EPISODE dispersion model (Slørdal et al., 2003, 2008), however, chemistry is usually not activated in dispersion simulations with the operational EPISODE model because the implemented chemistry scheme is very time consuming. Rather, $\mathrm{NO}_{2}$ concentrations are calculated using the photochemical steady-state assumption (Schneider et al., 2017). For air quality simulations with the CityChem model, the following set of schemes should be used: (1) the positive definite 4th degree Bott scheme (Bott, 1989, 1993) for horizontal advection; (2) the fully explicit forward Euler scheme (Smith, 1985) for horizontal diffusion; (3) the vertical upstream advection and semi-implicit Crank-Nicholson diffusion scheme (Byun et al., 1999) and (4) the "CC45" chemical scheme solved with modified TWOSTEP algorithm (Verwer and Simpson, 1995), described in Sect. S4 of the Supplement.

CityChem has the option to use the time-varying 3-D concentration field at the lateral and vertical boundaries from CMAQ model (Byun and Schere, 2006) as initial and boundary concentrations for selected chemical species. The regional background concentrations are adopted for the grid cells (outside the computational domain) directly adjacent to the boundary grid cells of the model domain and for the vertical model layer that is on top of the highest model layer. Physically, the solution of the 
Geosci. Model Dev. Discuss., https://doi.org/10.5194/gmd-2018-8

Manuscript under review for journal Geosci. Model Dev.

Discussion started: 24 January 2018

(c) Author(s) 2018. CC BY 4.0 License.

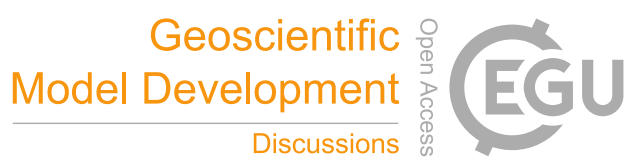

(c) (i)

advection equation is not affected by the downwind concentrations, but since the wind direction varies over time, it is necessary in practice to prescribe boundary conditions at all edges of the study domain. The outside grid cell directly adjacent to boundary grid cell is filled with the CMAQ concentration value for inflow conditions and with the concentration value of the boundary grid cell for outflow conditions (zero-concentration gradient at the outflow boundary).

5 The problem of spurious wave reflections at the outflow boundary due to imposing a condition at the outflow boundary is addressed by modification of Bott's scheme for advection near the boundaries. A 1st order polynomial is used in the boundary grid cell $((1, y)$ or $(x, 1))$ to compute the flux out of the domain. A 2nd order polynomial is used in the first cell of the inner domain $((2, y)$ or $(x, 2))$ and a 4th order polynomial is used in the second cell of the inner domain $((3, y)$ or $(x, 3))$ and the other cells of the inner domain. As a test of the model's treatment of boundary conditions, the entrainment of ozone and $\mathrm{PM}_{2.5}$ from the boundaries into the inner domain for constant wind direction was studied in an artificial simulation, described in Sect. 3.1.

The Eulerian model component computes the horizontal and vertical eddy diffusivities from mean meteorological variables and scaling parameters. Since the eddy diffusivities depend on the spatial structure of the flow field and on the grid resolution, their values need to be parameterised in order to account for both effects. Transport of pollutants in vertical direction is often dominated by turbulent diffusion. The parameterisation of the vertical eddy diffusivity therefore has important consequences for the vertical concentration profiles.

In CityChem, the model user can chose between two different parameterisations of the vertical eddy diffusivity for different stability regimes of the PBL: (1) the standard $K^{(z)}$-method, which is the default in the EPISODE dispersion model and (2) the new urban $K^{(z)}$-method which is newly implemented in the CityChem model. The stability regime is defined with a nondimensional number $z / L$, where $z$ is the height above the ground and $L$ is the Monin-Obukhov length. In accordance with $\mathrm{K}$-theory it is assumed that chemical species have non-dimensional profile characteristics similar to potential temperature, $\theta$, such that $K^{(z)}$ equals the eddy diffusivity of the heat flux, $K_{H}$. In order to model the turbulent processes in the PBL in a realistic manner, it is essential to consider the vertical variation of the exchange coefficients. In the explicit closure schemes used here, a profile is prescribed to account for the vertical variation of the turbulent exchange coefficients.

The applied vertical eddy diffusivity, $K^{(z)}$, is defined as a sum of two terms:

$25 K^{(z)}=K_{*}^{(z)}+K_{0}^{(z)}$,

where $K_{*}^{(z)}$ is a parameterisation depending on stability regime and $K_{0}^{(z)}$ is an added background diffusivity term. The additional term is only applied within the boundary layer.

The standard $K^{(z)}$-method is based upon the description given in Byun et al. (1999) and included in Sect. S1 of the Supplement. The standard $K^{(z)}$-method uses a constant background diffusivity of $K_{0}^{(z)}=0.01 \mathrm{~m}^{2} \mathrm{~s}^{-1}$.

The new urban $K^{(z)}$-method is described in the following:

For neutral conditions the expression from Shir (1973) is adopted:

$K^{(z)}=\kappa u_{*} z \exp \left(-\frac{8 \mathrm{f} z}{u_{*}}\right)$, 
Geosci. Model Dev. Discuss., https://doi.org/10.5194/gmd-2018-8

Manuscript under review for journal Geosci. Model Dev.

Discussion started: 24 January 2018

(c) Author(s) 2018. CC BY 4.0 License.

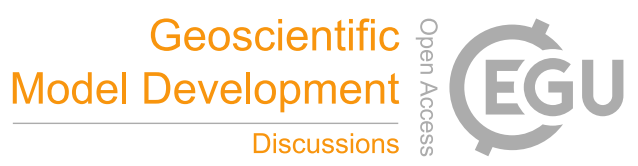

(c) (i)

where $\kappa=0.41$ is the Von Kármán constant, $u_{*}$ is the friction velocity $\left(\mathrm{m} \mathrm{s}^{-1}\right)$ and $\mathrm{f}$ is the Coriolis parameter. For unstable conditions the expression by Lamb and Durran (1978) is used.

Businger and Arya (1974) developed a steady state, first-order numerical $K$-model based on a non-dimensional eddy viscosity derived from the empirical log-linear profile for the stable atmospheric surface layer. The formulation of the nondimensional temperature gradient given by Beljaars and Holtslag (1991) is utilized in the new urban $K^{(z)}$-method for stable conditions:

$\Phi_{\mathrm{H}}=1+\frac{z}{L}\left[\alpha \sqrt{1+\frac{2}{3} \frac{\alpha z}{L}}+\beta e^{-\delta \frac{z}{L}}\left(1+\gamma-\delta \frac{z}{L}\right)\right]$,

where the suggested values of the empirical coefficients are (Beljaars and Holtslag, 1991): $\alpha=1, \beta=2 / 3, \gamma=5$, and $\delta=0.35$. The expression of Businger and Arya (1974) for the vertical eddy diffusivity under stable conditions is modified by replacing the temperature gradient parameterisation from Businger et al. (1971) by Eq. (3). The parameterisation for stable conditions consequently becomes:

$K_{*}^{(z)}=\frac{\kappa u_{*} z}{0.8\left(1+\frac{z}{L}\left[\alpha \sqrt{1+\frac{2 \alpha z}{3 L}}+\beta e^{-\delta \frac{z}{L}}\left(1+\gamma-\delta \frac{z}{L}\right)\right]\right)} \exp \left(-\frac{8 \mathrm{f} z}{u_{*}}\right)$.

Note that the expression from Beljaars and Holtslag (1991) is scaled by 0.8 to be in better agreement with the temperature gradient from LES computations of the stable boundary layer by Basu and Porté-Agel (2006).

The new urban $K^{(z)}$-method considers a baseline turbulent mixing due to the urban roughness and anthropogenic heating effect in cities, with an apparent eddy diffusivity of (Slørdal et al., 2003):

$K_{*}^{(0)}=\left\{\begin{array}{lll}\left(2 \Delta z_{1}\right)^{2} / 3600 \mathrm{~s} & \text { for } & u_{*}>0.2 \mathrm{~m} \mathrm{~s}^{-1} \\ \left(\Delta z_{1}\right)^{2} / 3600 \mathrm{~s} & \text { for } & u_{*}<0.1 \mathrm{~m} \mathrm{~s}^{-1},\end{array}\right.$

with a linear variation of $K_{0}^{(z)}$ between the two $u_{*}$ limits.

The particular choice of $K_{0}^{(z)}$ is based on a scale analysis where it is assumed that the respective minimum values of $K^{(z)}$ should be large enough, during a one hour period, to mix an air-column of thickness $\Delta z_{1}$ or $2 \Delta z_{1}$, (thickness of the surface layer, i.e. the lower-most model layer), when $u_{*}$ is less than $0.1 \mathrm{~m} \mathrm{~s}^{-1}$ or larger than $0.2 \mathrm{~m} \mathrm{~s}^{-1}$, respectively (Slørdal et al., 2003). For $u_{*}$ less than $0.1 \mathrm{~m} \mathrm{~s}^{-1}$ and $\Delta z_{1}=20 \mathrm{~m}, K_{0}^{(z)}$ becomes equal to $0.11 \mathrm{~m}^{2} \mathrm{~s}^{-1}$. For $u_{*}$ greater than $0.2 \mathrm{~m} \mathrm{~s}^{-1}$ and $\Delta z_{1}=20 \mathrm{~m}$, $K_{0}^{(z)}$ becomes equal to $0.44 \mathrm{~m}^{2} \mathrm{~s}^{-1}$. A test of the two different parameterisations for the vertical eddy diffusivity is presented in Sect. 3.2.

The chemical scheme used for the gas-phase chemistry in the Eulerian model component is based on a simplified version of the default chemistry scheme "EmChem09" of the EMEP MSC-W model (Simpson et al., 2012). The CityChem chemistry scheme "CC45" consists of 45 gas-phase species, 51 thermal reactions and 16 photolysis reactions. The chemical pre-processor of the EMEP model (GenChem) is used to convert lists of input chemical species and reactions to differential equations in FORTRAN code. Table S2 in the Supplement summarizes the chemical reactions and rate constants of the CityChem chemistry scheme. The numerical solution of the differential equations for chemical production and loss terms is described in Sect. S4. In 
Geosci. Model Dev. Discuss., https://doi.org/10.5194/gmd-2018-8

Manuscript under review for journal Geosci. Model Dev.

Discussion started: 24 January 2018

(c) Author(s) 2018. CC BY 4.0 License.

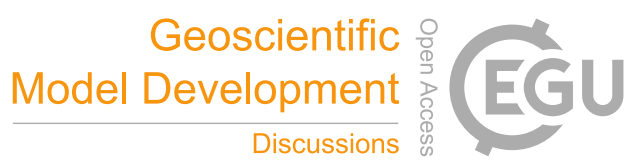

(c) (i)

artificial test simulations the effect of the variation of $\mathrm{NO}_{\mathrm{X}}$ emissions and non-methane VOC (NMVOC) emissions on ozone production is shown in Sect. 3.3.

The main simplification compared to "EmChem09" is the neglect of the peroxy radical self-reactions. This appears to be justified since the CityChem model is only applied for polluted urban environments. The self-reactions of peroxy radicals,

5 either between organic peroxy radical $\left(\mathrm{RO}_{2}\right)$ and hydrogen peroxy radical $\left(\mathrm{HO}_{2}\right)$, or between two organic peroxy radicals,

$$
\begin{array}{lll}
\mathrm{HO}_{2}+\mathrm{HO}_{2} & \longrightarrow & \mathrm{H}_{2} \mathrm{O}_{2}+\mathrm{O}_{2} \\
\mathrm{RO}_{2}+\mathrm{HO}_{2} & \longrightarrow & \mathrm{RO}_{2} \mathrm{H}+\mathrm{O}_{2} \\
\mathrm{RO}_{2}+\mathrm{RO}_{2} & \longrightarrow & \text { products }
\end{array}
$$

are in competition with the reaction of $\mathrm{RO}_{2}$ (or $\mathrm{HO}_{2}$ ) with $\mathrm{NO}$ leading to photochemical ozone formation:

$\mathrm{RO}_{2}+\mathrm{NO} \longrightarrow \mathrm{RO}+\mathrm{NO}_{2}$

At ambient levels of $\mathrm{NO}_{\mathrm{X}}\left(\mathrm{NO}_{\mathrm{X}}=\mathrm{NO}+\mathrm{NO}_{2}\right)$ typical of moderately or more polluted areas, reactions (R1) - (R3) will be negligible compared with reaction (R4). Thus, all reactions of organic peroxy radicals of type (R2) and (R3) were omitted in the "CC45" scheme. However, due to their relevance, the reaction of $\mathrm{HO}_{2}$ with the methyl peroxy radical $\left(\mathrm{CH}_{3} \mathrm{O}_{2}\right)$ and the $\mathrm{HO}_{2}$ self-reaction (R1) were included.

A second simplification compared to "EmChem09" was to replace the fairly detailed isoprene $\left(\mathrm{C}_{5} \mathrm{H}_{8}\right)$ reaction scheme in this mechanism by a simple four-reaction scheme for the oxidation of isoprene with the hydroxyl $(\mathrm{OH})$ radical.

The photo-dissociation coefficients of photolysis reactions, $J_{n}$, are calculated according to the expression:

$J_{n}= \begin{cases}\operatorname{CLF}_{n} \varepsilon_{1, n} \exp \left(\varepsilon_{2, n} / \cos \left(\theta_{z}\right)\right) ; & \theta_{z}<60^{\circ} \\ \operatorname{CLF}_{n} \varepsilon_{1, n} \exp \left(\varepsilon_{2, n} \alpha_{0}\left(\theta_{z}\right)\right) ; & 60^{\circ} \leq \theta_{z}<89^{\circ} \\ \operatorname{CLF}_{n} \varepsilon_{1, n} \exp \left(\varepsilon_{2, n} \alpha_{0}\left(89^{\circ}\right)\right) ; & \theta_{z} \geq 89^{\circ},\end{cases}$

where $\theta_{z}$ is the zenith angle, $\alpha_{0}$ denotes the optical air mass for large zenith angles, and $\operatorname{CLF}_{n}$ is the cloud correction factor for reaction number $n$ :

$\mathrm{CLF}_{n}= \begin{cases}(1.0-\mathrm{CL} / 0.2)+\varepsilon_{3, n} \mathrm{CL} / 0.2 ; & \mathrm{CL} \leq 0.2 \\ \varepsilon_{3, n}+(\mathrm{CL}-0.2)\left(\varepsilon_{4, n}-\varepsilon_{3, n}\right) / 0.6 ; & \mathrm{CL}>0.2 .\end{cases}$

The actual fractional cloud cover of low clouds (0.0 to 1.0), CL, is either based on observational data of cloud coverage or from the total solar radiation field (calculated by TAPM) using the approximation for the transmission coefficient of short wave radiation suggested by Burridge and Gadd, as given in Stull (1988). Empirical values for $\varepsilon_{1}, \varepsilon_{2}, \varepsilon_{3}$ and $\varepsilon_{4}$ for the photolysis reactions included in "CC45" are tabulated in Table S2.

The sink terms for dry deposition and wet removal of gases and particles are presented in Appendix A. 
Geosci. Model Dev. Discuss., https://doi.org/10.5194/gmd-2018-8

Manuscript under review for journal Geosci. Model Dev.

Discussion started: 24 January 2018

(c) Author(s) 2018. CC BY 4.0 License.

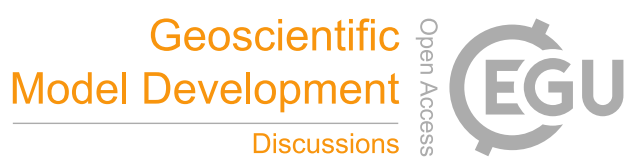

(c) (i)

\subsection{Description of the Gaussian sub-grid model components}

Sub-grid models to resolve the dispersion close to point emission sources and line emission sources are embedded in CityChem to account for sub-grid variations as a result of emissions along open roads and streets as well as along plume trajectories from elevated point source releases. In the CityChem model, a regular receptor grid is defined, for which time-dependent surface concentrations of the pollutants at receptor points are calculated by summation of the Eulerian grid concentration of the corresponding grid cell (i.e. the background concentration), and the concentration contributions from the sub-grid models due to line source and point source emissions.

The sub-grid model for point emission sources, e.g. stacks of industrial plants and power plants, is the Gaussian segmented plume trajectory model SEGPLU (Walker and Grønskei, 1992). The sub-grid model for line sources, i.e. open road and urban street traffic, is the Gaussian model HIWAY-2 (Petersen, 1980) from US EPA with modifications. SEGPLU and HIWAY-2 are part of the operational EPISODE dispersion model. In this section only modifications to the sub-grid models within CityChem are described, while the point source sub-grid model is documented in Sect. S2 of the Supplement and the line emission subgrid model is documented in Sect. S3 of the Supplement.

At the local receptor grid points only a simplified chemistry is considered. Only a small portion of $\mathrm{NO}_{\mathrm{X}}$ from motor vehicles and combustion sources is in the form of $\mathrm{NO}_{2}$, the main part being $\mathrm{NO}$. The largest fraction of ambient $\mathrm{NO}_{2}$ originates from the subsequent chemical oxidation of NO. The only reactions considered to be relevant in the vicinity of $\mathrm{NO}_{\mathrm{X}}$ emission sources are:

$$
\begin{array}{lll}
\mathrm{NO}+\mathrm{O}_{3} & \longrightarrow \mathrm{NO}_{2}+\mathrm{O}_{2} \\
\mathrm{NO}_{2}+\mathrm{h} v & \longrightarrow \mathrm{NO}+\mathrm{O}\left({ }^{3} \mathrm{P}\right)
\end{array}
$$

$\mathrm{O}\left({ }^{3} \mathrm{P}\right)+\mathrm{O}_{2} \longrightarrow \mathrm{O}_{3}$

Reaction (R7) between the oxygen radical $\left(\mathrm{O}\left({ }^{3} \mathrm{P}\right)\right)$ and molecular oxygen $\left(\mathrm{O}_{2}\right)$ is very fast, hence the reaction system can be reduced to (1) the production of $\mathrm{NO}_{2}$ due to the reaction of $\mathrm{NO}$ with $\mathrm{O}_{3}$ (with reaction coefficient $k\left(\mathrm{O}_{3}+\mathrm{NO}\right)$ and (2) the photodissociation of $\mathrm{NO}_{2}$ leading to the recycling of $\mathrm{NO}$ and $\mathrm{O}_{3}$ (with photo-dissociation coefficient $J_{\mathrm{NO}_{2}}$ ). Further, an instantaneous equilibrium between the three reactions relating $\mathrm{NO}, \mathrm{NO}_{2}$ and $\mathrm{O}_{3}$ is assumed, the photo-stationary state, implying that the residence time of pollutants on the sub-grid scale is much larger than the chemical reaction time scale. The solution for the photo-stationary state is found from a second-order equation in $\mathrm{O}_{3}$, and the ambient $\mathrm{NO}_{2}$ concentration (at the receptor point) is found by subsequent insertion.

During wintertime in Northern Europe, the photo-stationary state assumption is a rather good approximation of the photochemical conversion occurring close to the emission sources. However, when the solar ultraviolet (UV) radiation is stronger, in particular during summer months or at more southerly locations, net ozone formation may take place in urban areas at a certain distance from the main emission sources (Baklanov et al., 2007). A test of the ozone formation near sources was performed using the built-in numerical chemistry solver for the sub-grid photochemistry (Sect. 3.4). 
Geosci. Model Dev. Discuss., https://doi.org/10.5194/gmd-2018-8

Manuscript under review for journal Geosci. Model Dev.

Discussion started: 24 January 2018

(c) Author(s) 2018. CC BY 4.0 License.

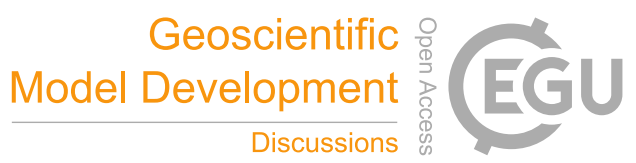

(c) (i)

SEGPLU computes and keeps record of the subsequent positions of the plume segments released from a point source and the corresponding pollutant concentration within each plume segment. Vertical position of the plume segment is calculated from the plume rise of the respective point source. Plume rise due to momentum or buoyancy is calculated using the plume rise equations originally presented by Briggs $(1969,1971,1975)$ and takes into account different boundary layer (BL) stability conditions as characterized by the inverse Monin-Obukhov length. In CityChem, the plume rise module was modified according to "NILU plume" presented in Karl et al. (2014). The physical stack height is modified according to Briggs (1974) to account for situations with stack downwash. Final plume rise is calculated considering the effects of (1) the adjacent building due to building-induced disturbances of the flow (Briggs, 1974); (2) penetration through an elevated stable layer; and (3) topography. Input parameters such as pollutant emission rates, stack height, diameter, exhaust gas temperature and exit velocity as well as height and width of the building adjacent to the stack can be provided for each point source by the model user. The dispersion of $\mathrm{SO}_{2}$ emitted from an elevated point source was studied in an artificial test simulation (Sect. 3.5).

The street canyon treatment in HIWAY-2 considers the line emission source to be a depressed highway with the source located at the top of the cut section, at release height $0 \mathrm{~m}$ above ground. Above the cut section, pollutants are dispersed freely away from the highway. The procedure to determine pollutant concentrations downwind the cut section is identical to the procedure for an at-grade street. HIWAY-2 is not used for the receptors which are located directly on the highway or in the cut section, i.e. within a street canyon. A receptor point that is closer than a minimum distance of $R_{\min }$ from the line source is moved away to a distance $\mathrm{R}_{\min }$ (see Fig. 3) in order to be outside of the cut section.

In CityChem, the option to use a simplified street canyon model (SSCM) to compute concentrations for the receptor points in the cut section is introduced. The implemented street canyon model follows in most aspects the Operational Street Pollution Model (OSPM; Berkowicz et al., 1997). The complex and divers geometry of street canyons is approximated by three generic types for which average street canyon geometry properties are applied (Table 2). Each line source for which the geometric mid-point is located in a grid cell with urban land use (land use classes 32-35 defined in TAPM) is identified as potential street canyon. A disadvantage of this method is that some streets and roads, especially in the sparse-built urban areas outside the inner city, will be classified as street canyon despite being open roads with open spaces between buildings. A refinement of the street canyon treatment will be subject to future developments with CityChem.

For simplification, it is assumed that all buildings at the street canyon line source have the same average building height, $H_{s c}$, and that there are no gaps between the buildings. The average building heights for the TAPM land use classes were obtained by intersection of the 3-D city model LoD1-DE Hamburg (LGV, 2014) - which contains individual building heights - with the urban land use information of CORINE (CLC, 2012). The width of the street canyon, $W_{\mathrm{sc}}$, is defined as twice the width of the (line source) street width $W$, to account for sidewalks and to avoid too narrow canyons. The length of the street canyon, $L_{\mathrm{sc}}$, corresponds to the length of the line source within the grid cell.

It is assumed that emissions from traffic are distributed homogeneously along the line source segment which is inside the street canyon area, which means emissions are assumed to be distributed homogeneously over the street canyon in the full length and width of the canyon. A fundamental assumption of the street canyon model is that when the wind blows over a rooftop in a street canyon, an hourly averaged recirculation vortex is always formed inside the canyon (Hertel and Berkowicz, 
Geosci. Model Dev. Discuss., https://doi.org/10.5194/gmd-2018-8

Manuscript under review for journal Geosci. Model Dev.

Discussion started: 24 January 2018

(c) Author(s) 2018. CC BY 4.0 License.

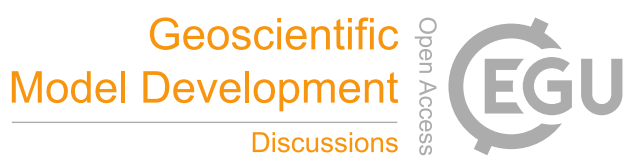

(c) (i)

1989). The part of the street canyon covered by the vortex of recirculating air is called the recirculation zone. The maximum extension of the recirculation zone, $L_{\mathrm{rec}}$, is estimated according to Ottosen et al. (2015).

The contribution of a line source $s$ to the receptor concentration located within the cut section, i.e. the urban street canyon is the sum of the direct contribution $\left(C_{\mathrm{scdir}, s}\right)$ from the traffic plume plus a contribution from the recirculation of the traffic plume $\left(C_{\text {screc,s}, s}\right)$ due to the vortex inside the canyon (Berkowicz et al., 1997)):

$C_{\text {line }, s}=C_{\mathrm{scdir}, s}+C_{\mathrm{screc}, s}$.

The leeward receptor inside a street canyon is exposed to the direct contributions from the emissions inside the recirculation zone (unless the wind direction is close to parallel) and a recirculation contribution. For the receptor on the windward side, only the emissions outside the recirculation zone are taken into account for the direct contribution. If the recirculation zone extends through the whole canyon, no direct contribution is given to the windward receptor. More details about the SSCM are given in Sect. S4 of the Supplement.

\subsection{Interactions between Eulerian grid and receptor grid}

On the Eulerian grid, time-dependent 3-D concentration fields of the pollutants are calculated by solving the advection/diffusion equation with terms for chemical reactions, dry deposition and wet deposition, and area emissions. The hourly 2-D and 3-D fields of meteorological variables and the hourly 2-D fields of area emissions are given as input to the model with the spatial resolution of the Eulerian grid. Emissions from point sources are added to the Eulerian grid concentration each time step. Emissions from line sources are added to the grid concentrations following a procedure described in more detail below.

The 3-D Eulerian grid and the regular receptor grid at the surface both have their own book-keeping to ensure conservation of pollutant mass. As the model steps forward in time, an accurate account of the total pollutant mass from area- and linesources is kept within the Eulerian grid model component. Figure 2 illustrates the combination of an Eulerian main grid (black dotted grid lines) and the regular receptor grid (blue dots) for the surface layer (ground air). The establishment of a regular receptor grid is an integral part of CityChem to enable higher resolution output required for comparison with monitor data acquired near line sources. Line sources are a major source of pollutant emissions affecting the inner-city air quality; thus the use of the regular receptor grid provides information at much higher spatial resolution than the Eulerian grid output alone. The regular receptor grid in the CityChem model differs from the downscaling approach by Denby et al. (2014) which allocates sampling points at high density along roads and other line sources but much fewer further away from the line sources. While Denby et al. (2014) interpolate the model-computed high-density set of receptor concentrations to the desired output resolution using ordinary kriging, CityChem gives as output the receptor point concentrations with high resolution, usually $100 \times 100 \mathrm{~m}^{2}$, covering the entire model domain.

The hourly concentration $C_{\text {rec }}$ in an individual receptor point $r^{*}$ of the receptor grid with coordinates $\left(x_{r}, y_{r}, z_{r}\right)$ is defined as:

$C_{\mathrm{rec}}\left(r^{*}\right)=C_{m}+\sum_{s=1}^{S} C_{\text {line }, s}+\sum_{p=1}^{P} C_{\mathrm{point}, s}$,

where $C_{m}$ is the hourly main grid concentration of the grid cell $(x, y, z)$ in which the receptor point is located. 
Geosci. Model Dev. Discuss., https://doi.org/10.5194/gmd-2018-8

Manuscript under review for journal Geosci. Model Dev.

Discussion started: 24 January 2018

(c) Author(s) 2018. CC BY 4.0 License.

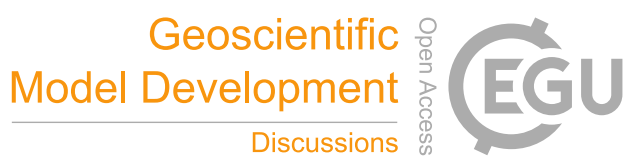

(c) (i)

The grid (background) concentration $C_{m}$ used in Eq. (9) corresponds to a modified Eulerian 3-D grid concentration, i.e. $C(x, y, z)$, to avoid that emissions of point and lines sources are counted twice. $C_{\mathrm{point}, p}$ is the hourly concentration contribution of point source $p$ calculated by the point source sub-grid (Sect. S2) and $C_{\text {line,s }}$ is the hourly concentration contribution of line source $s$ calculated by the line source sub-grid model (Sect. S3).

An individual receptor point $r^{*}$ is influenced by surrounding line sources when it lies within a certain distance from the line, the so-called influence distance. The sub-grid concentration contributions from all $S$ lines, for which $r^{*}$ is lying within the influence distance $\left(\mathrm{R}_{\mathrm{inf}}\right)$, are summed up and added to the total concentration at the receptor point. The specific influence distance can be defined by the model user for each line source; however the maximum influence distance is defined as half of the grid width in $\mathrm{x}$-direction $(\Delta X / 2)$. By this, a rectangular influence zone around each line is resulting, as shown in Fig. 3 (grey-shaded area).

All $P$ concentration contributions from plume segments calculated by the sub-grid point source model, depending on the segment's advection time between release of the plume segment and arrival at the receptor point, are added to the receptor point concentration according to Eq. (9).

The receptor point concentration $C_{\text {rec }}$ is calculated each time step based on current Eulerian grid concentrations and subgrid concentration contributions. Since $C_{\text {rec }}$ is not added to the main grid concentration, but kept as separate (diagnostic) variable, double-counting of emitted pollutant mass is prevented. Receptor point concentrations are thought to represent the high-resolution ground concentration of a cell with grid cell area of the receptor (sampling) grid.

Line source emissions in CityChem are contributing to the Eulerian grid concentrations during each advection time step. Each line source contributes to the grid cell concentration $C(x, y, z)$ according to the following equation:

$C(x, y, z)=C(x, y, z)+w_{s}(x, y, z) \frac{\Omega_{s}}{V(x, y, z)}$,

where $\Omega_{s}$ is the mass emitted from the line source $s$ during the current hour, $V(x, y, z)$ is the volume of the grid cell, and $w_{s}(x, y, z)$ is a weighting function that determines how much of the mass emitted from line source $s$ is injected into grid cell $(x, y, z)$. The weighting function is simply given as:

$w_{s}(x, y, z)=\frac{C_{\text {line }, s}(x, y, z)}{\sum_{\forall x, y, z} C_{\text {line }, s}(x, y, z)}$,

where $C_{\text {line,s }}(x, y, z)$ is the concentration contribution from line source $s$ in the midpoint of the Eulerian grid cell $(x, y, z)$ and the denominator of Eq. (11) is the sum of the concentration contributions from this line source to all of the grid cell midpoints within the model domain.

A special case occurs when the line source is close to the model domain boundary and the wind direction is such that the denominator in Eq. (11) becomes zero. In this case the mass from this line source is distributed within the grid cell containing the line source midpoint. Similarly, the contribution found from all $S$ line sources is treated according to the following expression:

$C(x, y, z)=C(x, y, z)+\sum_{s=1}^{S} w_{s}(x, y, z) \frac{\Omega_{s}}{V(x, y, z)}$.

The change of the Eulerian grid model concentrations specified in Eq. (12) should be considered as an adjustment of the initial concentration distribution before starting the model calculations for the next simulation hour. 
Geosci. Model Dev. Discuss., https://doi.org/10.5194/gmd-2018-8

Manuscript under review for journal Geosci. Model Dev.

Discussion started: 24 January 2018

(c) Author(s) 2018. CC BY 4.0 License.

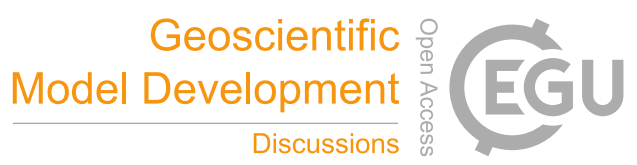

(c) (i)

\subsection{Pre-processing utilities}

The pre-processing utilities are provided together with the distribution of the CityChem model source code. A detailed description of the utilities is given in the User's Guide for CityChem, included in the CityChem distribution. The pre-processing utilities are:

1. MCWIND (utility to generate a diagnostic wind field);

2. BCONCC (interface to convert CMAQ concentration output);

3. UECT (interface for line source, point source, and area source emissions);

4. AERMAP (US EPA topography pre-processor);

5. TAPM4CC (interface to convert TAPM meteorology output);

6. Utilities to generate auxiliary input (z0top4cc, static4cc).

In addition the package postcchem containing routines written in NCL (NCAR Command Language) for the graphical plotting of CityChem model results is provided. Table 3 gives an overview of the purpose, input and output formats and descriptions of the pre-processing utilities.

For the preparation of input data for a CityChem simulation, a user metadata file run has to be configured. The user metadata file includes all meta information (model domain, resolution, time period, number of emission sources) required by the pre-processing utilities for meteorology (TAPM), boundary/background concentrations (CMAQ), emissions and the auxiliary data. The user metadata file is read by the interfaces for preparation of meteorology, boundary concentrations, emissions and auxiliary data.

The terrain pre-processor AERMAP (EPA-454/B-03-003, October 2004) of the U.S. EPA air dispersion model 20 AERMOD (U.S. EPA, 2004) can be used to create the topography input file in case TAPM is not available. The MCWIND utility produces a diagnostic wind field and other meteorological fields for the defined model grid, by first constructing an initial first-guess wind field based on the measurements of the horizontal wind at two heights (of a meteorological tower) at two or more meteorological stations. Then the horizontal 2-D fields are interpolated to the 3-D grid of the model domain by applying Monin-Obukhov similarity theory. Finally, the first-guess 3-D wind field is adjusted to the given topography by requiring the resulting wind field in each model layer to be non-divergent and mass-consistent.

\section{Performance of the chemistry-transport coupling}

In this section the different options and numerical uncertainties are tested with the use of synthetic tests that are based on the configuration of CityChem for a model test domain ("testcity") with a ground cell area of $9 \times 9 \mathrm{~km}^{2}$, flat terrain (15 m a.s.l.) and a daily cycle of meteorological conditions typical for July in Hamburg, Germany. Surface roughness and friction velocity were 
Geosci. Model Dev. Discuss., https://doi.org/10.5194/gmd-2018-8

Manuscript under review for journal Geosci. Model Dev.

Discussion started: 24 January 2018

(c) Author(s) 2018. CC BY 4.0 License.

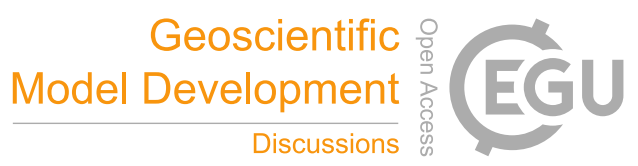

(c) (i)

kept constant and uniform throughout the domain $\left(z_{0}=0.8 \mathrm{~m} \mathrm{~s}^{-1}, u_{*}=0.12 \mathrm{~m} \mathrm{~s}^{-1}\right)$; wind was continuously from SW $\left(225^{\circ}\right)$ with a speed of $2 \mathrm{~m} \mathrm{~s}^{-1}$. Hourly varying meteorological variables included: air temperature, temperature gradient, relative humidity, sensible and latent heat fluxes, total solar radiation and cloud fraction. The test simulations are performed for a period of five days.

\section{3.1 Variation of boundary conditions}

The entrainment of boundary concentrations of $\mathrm{O}_{3}$ and $\mathrm{PM}_{2.5}$ into the model domain was studied using constant concentrations of the compounds at the lateral and vertical boundaries. Initially, all concentrations inside the model domain are zero. Photochemistry was switched off in all runs in order to treat $\mathrm{O}_{3}$ as chemically inert tracer. Horizontal and vertical advection/diffusion as well as dry deposition was activated. In a series of test runs, the boundary condition (BCON) value of $\mathrm{O}_{3}$ was increased from 30 to $80 \mu \mathrm{g} \mathrm{m}^{-3}$ in steps of $10 \mu \mathrm{g} \mathrm{m}^{-3}$ while the BCON value of $\mathrm{PM}_{2.5}$ was increased from 5 to $30 \mu \mathrm{g} \mathrm{m}^{-3}$ in steps of $5 \mu \mathrm{g} \mathrm{m}^{-3}$ between the runs. The spatial distribution of $\mathrm{O}_{3}$ and $\mathrm{PM}_{2.5}$ in the surface layer as average of the 5-day period were inspected.

The preferential mass flux due to horizontal advection is along the SW-NE diagonal. Fig. 4a and,4d show the spatial distribution of $\mathrm{O}_{3}$ and $\mathrm{PM}_{2.5}$, respectively, which decrease from SW to NE. The concentration decrease along the SW-NE diagonal of the domain occurs step wise (Fig. $4 \mathrm{~b}$ and $4 \mathrm{e}$ ). Grid cells on the diagonal inside the inner domain receive advected material not only from the cell to the southwest but also from the cells directly to the south and to the west (more than other cells). This, in competition with dry deposition which proportionally removes the material, causes the step wise decrease. Without removal by dry deposition, a surface field with homogeneous concentration corresponding to the BCON value results. Dry deposition is a strong removal process for $\mathrm{O}_{3}$ leading to a decrease by $8 \mu \mathrm{g} \mathrm{m}^{-3}$ after ca. $12 \mathrm{~km}$ for a BCON value of $60 \mu \mathrm{g} \mathrm{m}^{-3}$. On the other hand, $\mathrm{PM}_{2.5}$ decreased by only $0.6 \%$. Dry deposition acts as linear process upon the transfer of a non-reactive compound in atmospheric models. An exception is $\mathrm{SO}_{2}$, for which dry deposition might affect concentrations in a non-linear manner, because the canopy conductance of $\mathrm{SO}_{2}$ is strongly controlled by ammonia $\left(\mathrm{NH}_{3}\right)$ levels and the deposition of other acidic gases (Simpson et al., 2012). However, the present implementation of dry deposition does not take this into account.

As expected, the concentration in the centre grid cell of the model domain increases linearly with increasing BCON value (Fig. 4c and 4f). A linear fit to the modelled centre cell concentrations gave a slope of 0.914 and 0.996 for $\mathrm{O}_{3}$ and $\mathrm{PM}_{2.5}$, respectively. For a chosen $\mathrm{BCON}$ value, $\mathrm{O}_{3}$ and $\mathrm{PM}_{2.5}$ in the centre cell are reduced by $8.6 \%$ and $0.4 \%$ due to dry deposition. On the given spatial scale (ca. $12 \mathrm{~km}$ ), dry deposition negligibly affects the atmospheric lifetime of $\mathrm{PM}_{2.5}$.

\subsection{Vertical diffusion parametrization}

In the next test, the effect of the vertical eddy diffusivity parameterisation (standard versus new urban $K^{(z)}$-method) on the vertical profile of ozone was studied. Area emissions from traffic were added in all grid cells of the lowermost layer, with a rate of $0.25 \mathrm{~g} \mathrm{~s}^{-1} \mathrm{NO}_{\mathrm{X}}$ (NO:NO $\mathrm{NO}_{2}$ 90:10) and $0.25 \mathrm{~g} \mathrm{~s}^{-1}$ NMVOC (using the VOC split for traffic sources from the EMEP model) per cell. BCON values of $\mathrm{O}_{3}, \mathrm{NO}, \mathrm{NO}_{2}$ and VOCs were set to $60,5,10$, and $0 \mu \mathrm{g} \mathrm{m}^{-3}$, respectively. Photochemistry with the "CC45" mechanism was activated. 
Geosci. Model Dev. Discuss., https://doi.org/10.5194/gmd-2018-8

Manuscript under review for journal Geosci. Model Dev.

Discussion started: 24 January 2018

(c) Author(s) 2018. CC BY 4.0 License.

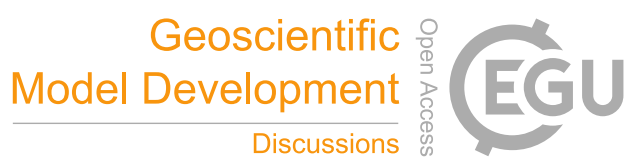

(c) (i)

Fig. 5 shows the time sequence of the vertical $\mathrm{O}_{3}$ concentration profile and the ground concentration changes of $\mathrm{O}_{3}$, NO, $\mathrm{NO}_{2}$ and total hydrocarbons (HC-tot) in the centre cell.

The nocturnal mechanically-mixed layer is typically much shallower than the convectively mixed layer during daytime. This is reflected in the test simulation. The mixed layer height at night is about $80 \mathrm{~m}$ in the test simulation while during daytime it is

5 well mixed up to $250 \mathrm{~m}$. In the stably stratified nocturnal PBL, the vertical exchange of $\mathrm{O}_{3}$ is limited, leading to a depletion in the surface layer due to titration with emitted NO from the traffic sources and partly through dry deposition. Ground level $\mathrm{O}_{3}$ in the grid centre cell decreases from 20 to $12 \mathrm{ppbv}$ in the simulation with the standard $K^{(z)}$-method and from 24 to $20 \mathrm{ppbv}$ in the simulation with the new urban $K^{(z)}$-method between noon and midnight.

There are clear differences in the vertical $\mathrm{O}_{3}$ profile and the ground air concentration levels of pollutants between the two parameterisations of vertical eddy diffusivity. Vertical ozone profiles shows a step gradient at night, increasing from 12 to 24 ppbv between 0 and $60 \mathrm{~m}$ above ground, for the standard $K^{(z)}$-method. With the new urban $K^{(z)}$-method the vertical distribution of $\mathrm{O}_{3}$ within the nocturnal mixed layer is more homogeneous, with a minimum (16-18 ppbv) in 10-25 m height above ground.

The more intense vertical exchange during night for the new urban $K^{(z)}$-method is also reflected in ground level pollutant concentrations. Maximum daytime ground level $\mathrm{O}_{3}$ with new urban $K^{(z)}$ is ca. $30 \%$ higher compared to the standard method.

15 Higher $\mathrm{O}_{3}$ concentrations lead to higher $\mathrm{OH}$ concentration (14\% higher at noon maximum), which in turn causes a faster decay of hydrocarbons. Maximum daytime $\mathrm{NO}_{2}$ is ca. $19 \%$ lower compared to the standard method, which is mainly due to the increased vertical mixing and partly due to a faster conversion to gaseous nitric acid $\left(\mathrm{HNO}_{3}\right)$ by reaction with $\mathrm{OH}\left(\mathrm{HNO}_{3}\right.$ is $26 \%$ higher), according to:

$\mathrm{NO}_{2}+\mathrm{OH}+\mathrm{M} \longrightarrow \mathrm{HNO}_{3}$

Modelled concentration time series of $\mathrm{O}_{3}, \mathrm{NO}$ and $\mathrm{NO}_{2}$ follow the photochemical reaction cycle described with reactions (R5) - (R7). The titration of $\mathrm{O}_{3}$ by reaction with $\mathrm{NO}$ (giving $\mathrm{NO}_{2}$; (R5)) at night can be clearly seen in Fig. 5c-d. Ozone production during the daylight period is evident from the two model simulations, as a result of the photo-dissociation of $\mathrm{NO}_{2}$, a reaction that occurs only in the presence of UV light. The resulting opposite day-night variation is reflected in $\mathrm{O}_{3}$ and $\mathrm{NO}_{2}$ concentrations being mirrored along the time axis. The conversion of $\mathrm{NO}$ to $\mathrm{NO}_{2}$ through $\mathrm{OH}$-initiated oxidation of hydrocarbons enhances ozone production. Photochemical ozone production in the model leads to a net increase of ground level $\mathrm{O}_{3}$ by ca. 7.5 and $5.5 \mathrm{ppbv}\left(15\right.$ and $\left.10 \mu \mathrm{g} \mathrm{m}^{-3}\right)$ for standard and new urban method, respectively.

Maximum pollutant concentration levels near emission sources at ground are often associated with strongly stable conditions and low wind speeds; such as during night-time and persistent daytime inversions in winter. Therefore it is important to simulate the turbulence in stable conditions of the nocturnal PBL in a realistic manner. There are several reasons to prefer the new urban $K^{(z)}$-method: (1) it takes into account a baseline turbulence due to the urban heat island effect, (2) it includes an updated treatment of the vertical diffusivity in stable conditions, and (3) it prevents too low modelled concentrations of ozone at ground in the stable nocturnal PBL. 
Geosci. Model Dev. Discuss., https://doi.org/10.5194/gmd-2018-8

Manuscript under review for journal Geosci. Model Dev.

Discussion started: 24 January 2018

(c) Author(s) 2018. CC BY 4.0 License.

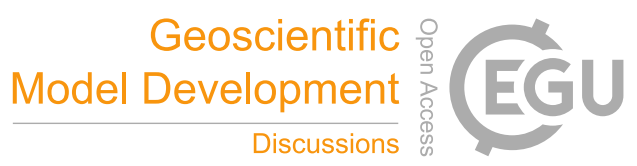

(c) (i)

\subsection{Test of the chemistry mechanism "CC45"}

The ozone-precursor relationship in urban environments are a consequence of the fundamental division into a $\mathrm{NO}_{\mathrm{X}}$-sensitive and a VOC-sensitive regime (Sillman, 1999). $\mathrm{VOC} / \mathrm{NO}_{\mathrm{X}}$ ratios are an important controlling factor for this division of chemical regimes. The ozone- $\mathrm{NO}_{\mathrm{X}}$-VOC sensitivity of "CC45" in the Eulerian model component was analysed by repeated runs for different ratios of $\mathrm{NO}_{\mathrm{X}}$ and $\mathrm{NMVOC}$ using the daily cycle of mean summer meteorology with clear sky but low wind speed $\left(0.1 \mathrm{~m} \mathrm{~s}^{-1}\right)$. The ozone net production was taken from the maximum amount of $\mathrm{O}_{3}$ produced on the fifth simulation day in the centre cell. The variation of ozone precursor emissions from the traffic area sources was done in a systematic way in order to derive the ozone isopleth diagram (Fig. 6a), which shows the rate of $\mathrm{O}_{3}$ production $\left(\mathrm{ppbh}^{-1}\right.$ ) as function of $\mathrm{NO}_{\mathrm{X}}$ and $\mathrm{NMVOC}$ concentrations.

10 The "ridge line" of the ozone isopleth diagram marks the local maxima of the $\mathrm{O}_{3}$ production and divides two different photochemical regimes. Below the line is the $\mathrm{NO}_{\mathrm{X}}$-sensitive regime, where $\mathrm{O}_{3}$ increases with increasing $\mathrm{NO}_{\mathrm{X}}$ while it is hardly affected by increasing VOC. Above the line is the VOC-sensitive regime, where $\mathrm{O}_{3}$ increases with increasing VOC and decreases with increasing $\mathrm{NO}_{\mathrm{X}}$. The "ridge line" in Fig. 6a follows a line of constant $\mathrm{VOC} / \mathrm{NO}_{\mathrm{X}}$ ratio, in the case of "CC45" it is close to the ratio $10: 1$.

VOC-sensitive chemistry is most likely to occur in central locations in large cities. The rural areas downwind locations of the city are typically $\mathrm{NO}_{\mathrm{X}}$-sensitive. In terms of urban air quality control, a VOC-sensitive regime refers to situations in which a percent reduction in anthropogenic NMVOC would result in a significantly greater decrease in $\mathrm{O}_{3}$ relative to the same percent reduction in $\mathrm{NO}_{\mathrm{X}}$.

The traffic NMVOC mixture includes a high share of aromatics (35\%) represented by o-xylene in the model. Due to the high reactivity of the NMVOC mixture, the "ridge line" is tilted towards higher $\mathrm{VOC} / \mathrm{NO}_{\mathrm{X}}$ ratios compared to the ozone isopleths for a NMVOC mixture with lower reactivity.

The split into $\mathrm{NO}_{\mathrm{X}}$-sensitive and VOC-sensitive regimes is closely associated with sources and sinks of odd hydrogen radicals (defined as the sum of $\mathrm{OH}, \mathrm{HO}_{2}$ and $\mathrm{RO}_{2}$ ). Odd hydrogen radicals are produced in the photolysis of ozone and intermediate organics such as, for example, formaldehyde (HCHO). Odd hydrogen radicals are removed by the reactions that produce hydrogen peroxide (R2) and organic peroxides (R3). They are also removed by the reaction that produces $\mathrm{HNO}_{3}(\mathrm{R} 8)$.

When peroxides represent the dominant sink for odd hydrogen, then the sum of peroxy radicals is insensitive to changes in $\mathrm{NO}_{\mathrm{X}}$ or NMVOC. This is the case for the concentrations represented as solid and dash-dotted lines in Fig. 6c-d. Doubling $\mathrm{NO}_{\mathrm{X}}$ emissions from solid lines to dash-dotted lines only marginally changes the peroxy radical sum concentration (Fig. 6d).

When nitric acid is the dominant sink of odd hydrogen, the $\mathrm{OH}$ concentration is determined by the equilibrium between the producing reactions (e.g. photolysis of $\mathrm{O}_{3}$ ) and the loss reaction (R8) and thus decreases with increasing $\mathrm{NO}_{\mathrm{X}}($ Fig. $6 \mathrm{c}-\mathrm{d}$; from dashed to dotted lines), while it is either unaffected, or increases due to the photolysis of intermediate organics, with increasing NMVOC.

Plotting the isopleths for the ratio of the production rate of peroxides to the production rate of $\mathrm{HNO}_{3}$ (Fig. 6b), shows that this ratio is closely related to the split between $\mathrm{NO}_{\mathrm{X}}$-sensitive and VOC-sensitive regimes. The ratio is typically 0.9 or higher 
Geosci. Model Dev. Discuss., https://doi.org/10.5194/gmd-2018-8

Manuscript under review for journal Geosci. Model Dev.

Discussion started: 24 January 2018

(c) Author(s) 2018. CC BY 4.0 License.

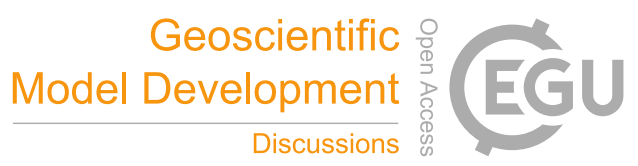

(c) (i)

for $\mathrm{NO}_{\mathrm{X}}$-sensitive conditions, and 0.1 or less for VOC-sensitive conditions (Sillman, 1999). The "ridge line" that separates the two regimes should be at a ratio of 0.5 (Sillman, 1999); which is the case in Fig. 6b. However, the curves representing the ratio are shifted towards higher $\mathrm{NO}_{\mathrm{X}}$ mixing ratios compared to the isopleth diagram for the ratio displayed in Sillman (1999; Figure 8 therein). For instance, for $100 \mathrm{ppbC}$ NMVOC and $5 \mathrm{ppb} \mathrm{NO}$, the ratio is below 0.1 (VOC-sensitive) in the 5 isopleth diagram of Sillman (1999), while it is 1.3 ( $\mathrm{NO}_{\mathrm{X}}$-sensitive) in Fig. 6b. The reason for this discrepancy is the lack of the reactions producing organic peroxides $\left(\mathrm{RO}_{2} \mathrm{H}\right)$ in " $\mathrm{CC} 45$ " and thus the reduced removal of odd hydrogen in conditions with high $\mathrm{VOC} / \mathrm{NO}_{\mathrm{X}}$ ratio. In conditions with $\mathrm{NO}_{\mathrm{X}}$ below about $20 \mathrm{ppbv}$, "CC45" has a too high efficiency of the $\mathrm{NO}^{-t o-\mathrm{NO}_{2}}$ conversion via reaction $(\mathrm{R} 4)$.

\subsection{Test of photochemistry in the sub-grid line source model}

10 One line source in the SE-NW diagonal (perpendicular to wind direction; wind speed $1 \mathrm{~m} \mathrm{~s}^{-1}$ ) with $\mathrm{NO}_{\mathrm{X}}$ and NMVOC emissions (both $7.9 \times 10^{-4} \mathrm{~g}(\mathrm{~s} \mathrm{~m})^{-1}$ ) was added in the "testcity" domain. The photochemistry of the sub-grid line source model was tested as follows: (1) no chemistry; (2) photochemical steady state assumption (PSSA) for $\mathrm{O}_{3} / \mathrm{NO} / \mathrm{NO}_{2}$ (default); and (3) with "CC10", a reduced version of "CC45" including only the inorganic reactions and the degradation of $\mathrm{HCHO}$, using the numerical solver. Photochemistry was activated on the Eulerian grid. Inside the centre cell, ground air concentrations downwind of

the line source were recorded using additional receptor points every $10 \mathrm{~m}$ up to a distance of $300 \mathrm{~m}$ from the line source. The same BCON values as in Sect. 3.2 were applied. Fig. 7a shows the surface concentration field of $\mathrm{O}_{3}$ for PSSA. The line source divides the $\mathrm{O}_{3}$ concentration field in two parts, with reduced $\mathrm{O}_{3}$ in the northeast part of the domain. Lowest $\mathrm{O}_{3}$ is found within a corridor of $500 \mathrm{~m}$ downwind of the line. Within the corridor, $\mathrm{O}_{3}$ is below $10 \mu \mathrm{g} \mathrm{m}{ }^{-3}$ directly at the line source and increases towards the northeast corner of each cell of the Eulerian grid, due to the wind from southwest and the elevated $\mathrm{NO}_{2}$.

Comparing $\mathrm{O}_{3}$ (black lines), $\mathrm{NO}_{2}$ (red lines) and $\mathrm{NO}$ (blue lines) concentrations from the three tests with increasing downwind distance $x$ (Fig. 7b) shows that dilution alone (test with no chemistry) leads to a decay of NO which follows a power function of the form $y=a x^{-b}$ while $\mathrm{O}_{3}$ remains constant because it is just advected through the grid cell with the line source. Applying the PSSA reduces $\mathrm{O}_{3}$ immediately at the line source by reaction (R5) to one fourth of the concentration without chemistry. At the line source, PSSA converts roughly $20 \mu \mathrm{g} \mathrm{m}^{-3} \mathrm{NO}$ to $30 \mu \mathrm{g} \mathrm{m}^{-3} \mathrm{NO}_{2}$, as deduced from the differences between the no chemistry and the PSSA test run. With the third option, "CC10", ozone is slightly increased in the first $50 \mathrm{~m}$. $\mathrm{HCHO}$ reacts with $\mathrm{OH}$ or undergoes photolysis to give $\mathrm{HO}_{2}$ radicals. $\mathrm{HO}_{2}$ competes with $\mathrm{O}_{3}$ for the available $\mathrm{NO}$ (reaction (R4)) and the reaction between $\mathrm{HO}_{2}$ and $\mathrm{NO}$ results in additional NO-to- $\mathrm{NO}_{2}$ conversion. $\mathrm{HCHO}$ accounts for only $2.7 \%$ of the traffic NMVOC emission, hence the effect on $\mathrm{O}_{3}$ and $\mathrm{NO}_{2}$ within $50 \mathrm{~m}$ distance of the road is notable.

The time scales characterising reactions (R5) -(R7) are of the order of tens of seconds, i.e. similar to the time scales of the exchange rate between the plume from the line source and the background air. The exchange rate is governed by the residence time of the pollutants at the street. However, in the sub-grid line source model, it is assumed that background $\mathrm{O}_{3}$ is instantaneously mixed with $\mathrm{NO}$ from the plume of the line source. The rate of the $\mathrm{NO}+\mathrm{O}_{3}$ reaction might therefore be overestimated in the sub-grid model, depending on the ambient conditions for the plume mixing. Due to the lack of $\mathrm{O}_{3}$ measurements at traffic monitoring stations, it is however difficult to evaluate how much the photochemistry is affected by the 
Geosci. Model Dev. Discuss., https://doi.org/10.5194/gmd-2018-8

Manuscript under review for journal Geosci. Model Dev.

Discussion started: 24 January 2018

(c) Author(s) 2018. CC BY 4.0 License.

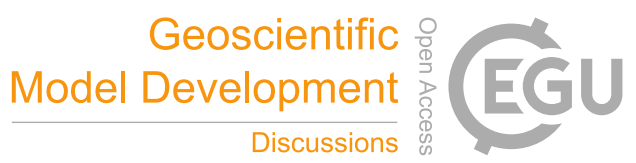

(c) (i)

plume mixing. Hertel and Berkowicz (1989) take the exchange rate into account for the PSSA and suggest that the residence time of pollutants in a street canyon can be approximated by $H_{s c} / \sigma_{w t}$, where $\sigma_{w t}$ is the ventilation velocity.

\subsection{Test of point source dispersion}

To test the integration of the sub-grid model SEGPLU in the Eulerian grid, the near-field dispersion around a point source was

5 studied for different atmospheric stability conditions. One point emission source is added at the midpoint of the grid centre cell. The dispersion of $\mathrm{SO}_{2}$, treated as non-reactive tracer, released from the point source stack was studied by sampling ground air concentrations from a regular receptor grid with 50-m resolution within a radius of $1.5 \mathrm{~km}$ around the point source. Resulting hourly ground concentrations (averaged for 5 days) at the location of maximum impact for different stability classes (stable, neutral, slightly unstable, very unstable) are summarized in Table 4.

The distance of the location of maximum ground concentrations increases from neutral to slightly stable to very unstable. The maximum impact lies within $180 \mathrm{~m}$ and $320 \mathrm{~m}$ downwind of the point source for the given stack parameterisation. With increased instability of the surface layer the maximum impact is shifted closer to the emitting stack due to the increased vertical mixing. Maximum ground concentrations in stable conditions are a factor of 100-200 smaller than in neutral and unstable conditions. In stable conditions, the plume released from the point source does not reach ground. Once the plume segment (at final plume height) reaches a critical horizontal and vertical extent, its material is inserted into the Eulerian grid cell containing its centre of mass. Vertical diffusion between the grid cells of the corresponding vertical 1-D column then causes downmixing of the highly diluted pollutant material to the ground.

\section{Application to air quality modelling for Hamburg}

An air quality (AQ) simulation with the CityChem model for Hamburg was run as part of a one-way nested model chain, which coupled the model off-line to the CMAQ v5.0.1 CTM (Byun and Schere, 2006) driven by COSMO-CLM mesoscale meteorological model version 5.0 (Rockel et al., 2008) for the year 2012 using the ERA-Interim re-analysis as forcing data (Geyer, 2014). CMAQ was run with temporal resolution of one hour over a European domain, an intermediate nested domain over Northern Europe and an inner nest over the Baltic Sea region with 64-km, 16-km and 4-km horizontal resolution, respectively (Fig. 8a). The chemical boundary conditions used for the European domain were taken from FMI APTA global reanalysis (Sofiev et al., 2018). The hourly meteorological fields for the study domain Hamburg $\left(30 \times 30 \mathrm{~km}^{2}\right)$ were obtained from the inner domain a nested simulation with TAPM (Hurley et al., 2005; Hurley, 2008) with a 1-km horizontal resolution (Fig. 8b).

The meteorological component of TAPM is an incompressible, non-hydrostatic, primitive equation model with a terrainfollowing vertical sigma coordinate for 3-D simulations. The outer domain (D1 in Fig. 8b) is driven by synoptic-scale meteorology of the Australian Bureau of Meteorology from six-hourly synoptic scale analyses on a longitude/latitude grid with

$301 \times 1$ degrees resolution. A vegetative canopy, soil scheme, and an urban scheme with 7 urban land use classes (Hurley, 2008) are used at the surface, while radiative fluxes, both at the surface and at upper levels, are also included. The terrain elevation 
Geosci. Model Dev. Discuss., https://doi.org/10.5194/gmd-2018-8

Manuscript under review for journal Geosci. Model Dev.

Discussion started: 24 January 2018

(c) Author(s) 2018. CC BY 4.0 License.

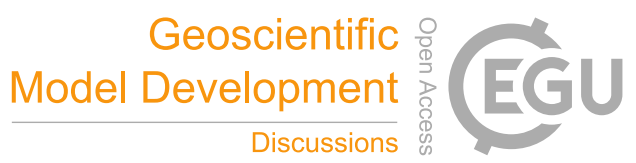

(c) (i)

data was adopted from the German Digital Elevation Model (BKG, 2013) on 200-m horizontal resolution and the land use information was adopted from the CORINE land cover database (CLC, 2012) on 100-m horizontal resolution.

CityChem was set up with the same vertical dimension and resolution matching that of TAPM, with a layer top at $3750 \mathrm{~m}$ height above ground, avoiding the need for vertical interpolation. The CityChem simulation was performed using the recom-

mended numerical schemes for physics and chemistry, the new urban parameterisation for vertical eddy diffusivity (Sect. 2.1), SEGPLU for sub-grid treatment of point source emissions, and HIWAY-2 without the street canyon option for sub-grid treatment of line source emissions.

Emissions for the study domain of Hamburg were used from various data sources for the different emission sectors classified by the Selected Nomenclature for sources of Air Pollution (SNAP) of the European Environmental Agency (EEA), applying top-down and bottom-up approaches. Table 5 gives an overview.

Spatially gridded annual emission totals with a grid resolution of $1 \times 1 \mathrm{~km}^{2}$ were provided for this study by the German Federal Environmental Agency (Umweltbundesamt, UBA). The spatial distribution of the annual emission totals for the grid areas has been done at UBA using the ArcGIS based software GRETA ("Gridding Emission Tool for ArcGIS"), which can generate regionalized emission data sets for all SNAP sectors for the complete area of the Federal Republic of Germany (Schneider et al., 2016). Hourly area emissions with 1-km horizontal resolution for SNAP categories 02 (domestic heating), 03 (commercial combustion), 06 (solvent and other product use), 08 (other mobile sources, not including shipping), and 10 (agriculture and farming) were derived from the UBA area emissions by temporal disaggregation using monthly, weekly and hourly profiles. Domestic heating emissions (SNAP cat. 02) for Hamburg are distributed between $32 \%$ district heating, $40 \%$ natural gas, $14 \%$ fuel oil and $14 \%$ electricity (Schneider et al., 2016). NMVOC emissions were distributed over individual VOC of the "CC45" mechanism using the VOC-split of the EMEP model (Simpson et al., 2012) for all SNAP sectors.

Line source emissions of $\mathrm{NO}_{\mathrm{X}}, \mathrm{NO}_{2}$ and $\mathrm{PM}_{10}$ were provided by the city of Hamburg. However a $\mathrm{NO}_{2} / \mathrm{NO}_{\mathrm{X}}$ ratio of 0.3 was applied to re-calculate $\mathrm{NO}_{2}$ emissions for this study because of the expected higher real-world $\mathrm{NO}_{2}$ emissions from diesel vehicles. The applied value is higher than suggested by the reported range (3.2-23.5 vol-\%) of the primary $\mathrm{NO}_{2}$ emission fraction from vehicular traffic in London (Carslaw and Beevers, 2005) and the $\mathrm{NO}_{2} / \mathrm{NO}_{\mathrm{X}}$ ratio of 0.22 for passenger cars in urban areas assumed by Keuken et al. (2012) for the Netherlands. But considerations based on the higher $\mathrm{NO}_{2} / \mathrm{NO}_{\mathrm{X}}$ ratio from diesel passenger cars (from 0.12 to $>0.5$; Carslaw and Rhys-Tyler, 2013) and the review by Grice et al. (2009) who assumed that Euro 4-6 passenger cars emit $55 \%$ of the total $\mathrm{NO}_{\mathrm{X}}$ as $\mathrm{NO}_{2}$, justify the use of the high $\mathrm{NO}_{2} / \mathrm{NO}_{\mathrm{X}}$ ratio for the Hamburg vehicle fleet. To estimate NMVOC traffic emissions, an average $\mathrm{VOC} / \mathrm{NO}_{\mathrm{X}}$ ratio of 0.588 , derived from UBA data for SNAP cat. 07, was used.

\subsection{Evaluation of TAPM meteorology}

The performance of the prognostic meteorological model component of TAPM for the study domain was evaluated in terms of temperature, relative humidity, total solar radiation, wind speed and wind direction. Hourly based data from the meteorological station at Hamburg Airport (Fuhlsbüttel) (operated by German Weather Service, DWD) and from the $280 \mathrm{~m}$ high Hamburg 
Geosci. Model Dev. Discuss., https://doi.org/10.5194/gmd-2018-8

Manuscript under review for journal Geosci. Model Dev.

Discussion started: 24 January 2018

(c) Author(s) 2018. CC BY 4.0 License.

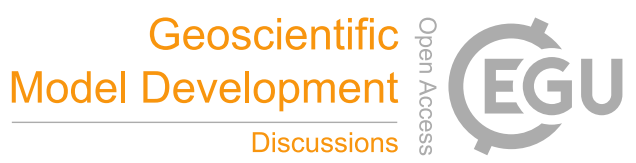

(c) (i)

weather mast at Billwerder (operated by University of Hamburg) was analysed. Observation data from the DWD station at $10 \mathrm{~m}$ height and from the Hamburg weather mast at $10 \mathrm{~m}$ and $50 \mathrm{~m}$ height was used in the analysis.

TAPM modelled meteorological data from the $1 \times 1 \mathrm{~km}^{2}$ grid cell of the D4 domain, where the stations are located, at the corresponding height were extracted for the comparison with observations. Table S3 in the Supplement provides an overview of the statistical analysis based on hourly data for 2012. Hourly temperature predicted by the TAPM model was in excellent agreement with observed temperature at both stations and both heights, showing high correlation $(r \geq 0.95)$ and small bias $\left(\leq 0.15^{\circ} \mathrm{C}\right)$. Relative humidity also showed good agreement but with lower correlation $(r=0.70)$. Total solar radiation was predicted by TAPM with good correlation $(r=0.81)$ but high positive bias. Situations with reduced solar radiation due to high cloud coverage are often not well captured by TAPM. The index of agreement (IOA) for temperature, relative humidity and total solar radiation was 0.98 (average of all observations), 0.83 and 0.89 , respectively.

TAPM shows good predictive capabilities for wind speed and direction. Modelled hourly data of wind speed at Hamburg weather mast, for both measurement heights, agreed well with the observations throughout the year (correlation: $r \geq 0.76$, bias: $0.01 \mathrm{~m} \mathrm{~s}^{-1}$ ), and was within the observed variability. Wind speed at the DWD station was slightly underestimated by TAPM (mean: $3.07 \mathrm{~m} \mathrm{~s}^{-1}$ ) compared to observations (mean: $3.94 \mathrm{~m} \mathrm{~s}^{-1}$ ). Southwest and west are the most frequent wind directions in Hamburg due to prevailing Atlantic winds, followed by winds from southeast (Bruemmer et al., 2012). Mean wind direction was computed as circular average (unit vector mean wind direction) for model and observation data. At DWD station, hourly data of wind direction modelled by TAPM was in good agreement with observations (IOA $=0.85$ ) and a small bias of $2.02^{\circ}$. At Hamburg weather mast, modelled and observed mean wind direction differed by $18.4^{\circ}$ and $8.3^{\circ}$ at $10 \mathrm{~m}$ and $50 \mathrm{~m}$ height, respectively. The difference is due to a slightly higher frequency of winds from west predicted by TAPM.

Overall, the TAPM model was capable of accurately reproducing the magnitude and variation at $10 \mathrm{~m}$ and $50 \mathrm{~m}$ above ground of the meteorological parameters which are most relevant for modelling the dispersion and photochemical transformation of air pollutants.

\subsection{Evaluation of the CityChem model with air quality monitoring data}

Evaluation of the CityChem model was done in a two stage procedure: first, the statistical performance of the comparison of modelled concentrations against observed concentrations was analysed; second the model performance with respect to the objectives set forth in the AQD for the use of the model in policy applications. The FAIRMODE (Forum for Air Quality Modelling in Europe) DELTA Tool version 5.5 (Thunis et al., 2012a, 2012b, 2013; Pernigotti et al., 2013; FAIRMODE, 2014) was used in both stages for the evaluation of model results for the air quality simulation for Hamburg. DELTA Tool is an Interactive Data Language (IDL) based statistical evaluation software which allows to perform diagnostics of air quality and meteorological model performance. The tool focuses on the air pollutants referred in the current AQD (EC, 2008). Delta Tool works with modelled-observed data pairs at surface level, i.e. temporal series of modelled and monitoring data at selected ground level locations, in particular at AQ monitoring stations.

A minimum data availability is required for statistics to be produced at a given AQ monitoring station. In DELTA Tool v. 5.5, the requested percentage of available data over a selected time period (here: one year) is $75 \%$ as defined in the AQD. This 
Geosci. Model Dev. Discuss., https://doi.org/10.5194/gmd-2018-8

Manuscript under review for journal Geosci. Model Dev.

Discussion started: 24 January 2018

(c) Author(s) 2018. CC BY 4.0 License.

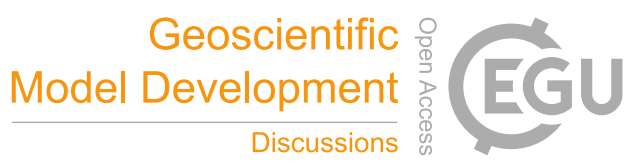

has been fulfilled by all stations in Hamburg, except for $\mathrm{O}_{3}$ and $\mathrm{PM}_{2.5}$ measurements at two stations. The stations of the AQ monitoring network of Hamburg and the available measurements of pollutant concentrations are listed in Table S4. The monitoring network covers all parts of the city (Fig. 8c). The statistical analysis included all stations where the data availability criterion was fulfilled. For the comparison, model output at the exact geographic location of the monitoring stations from the CityChem model was used. Concentrations of $\mathrm{NO}_{2}$ and $\mathrm{NO}$ were measured at all stations included in this study.

The model performance statistics is listed in Table 6 for $\mathrm{O}_{3}$ (based on daily max. of 8-h running mean), in Table 7 for $\mathrm{NO}_{2}$ (based on hourly values) and in Table 8 for $\mathrm{PM}_{10}$ (based on daily mean). Statistical indicators include the mean (modelled/observed), standard deviation (STD; modelled/observed), correlation coefficient (Corr), root mean square error (RMSE), normalized mean bias (NMB) and index of agreement (IOA). See Appendix B for definition of the statistical indicators.

The CityChem model performs fairly well for $\mathrm{O}_{3}$ daily max. of 8-h running mean, with IOA of 0.67 (average of all stations), correlation of 0.47 (average of all stations) and small NMB (within $\pm 13 \%$ ).

The CityChem model performs reasonably well for $\mathrm{NO}_{2}$ based on hourly values, with IOA of 0.52 (average of all stations), but high NMB (within $\pm 50 \%$ ). The model performs slightly better for the traffic stations than for urban background stations. Modelled hourly $\mathrm{NO}_{2}$ shows weak correlation with observed hourly $\mathrm{NO}_{2}(r=0.24$ as average of all stations). The weakest temporal relation between modelled and observed values was obtained for the urban background station 80KT (Altona-Elbhang). For most urban background stations, CityChem tends to under predict the observation mean.

The performance of CityChem for $\mathrm{PM}_{10}$ based on daily means is moderate, with IOA of 0.41 (average of all stations). Correlation values are generally low, with the maximum $(r=0.28)$ at station 61WB. The RMSE values for $\mathrm{PM}_{10}\left(12-23 \mu \mathrm{g} \mathrm{m}^{-3}\right)$ at the stations are in the range of RMSE of the models $\left(10.5-23 \mu \mathrm{g} \mathrm{m}^{-3}\right)$ used in the MACC-II ensemble daily forecast (Marécal et al., 2015) for Europe. At stations 70MB and 74BT modelled and observed $\mathrm{PM}_{10}$ were not related. CityChem was not capable to simulate observed particle peak concentrations from long/short-range transportation events. The low correlation is linked to uncertainties in the seasonal cycle of the anthropogenic PM emissions within the urban area.

Station Sternschanze (13ST) is an inner-city urban background monitoring site. This is the only station, where observations for all regulatory air pollutants considered in this study $\left(\mathrm{NO}_{2}, \mathrm{NO}, \mathrm{O}_{3}, \mathrm{SO}_{2}, \mathrm{PM}_{2.5}\right.$ and $\left.\mathrm{PM}_{10}\right)$ were available with required data coverage. Fig. 9 shows the quantile-quantile (Q-Q) plot for the daily mean concentrations at station 13ST for all days of 2012. The Q- Q plot is a graphical technique for comparing the probability distributions of the modelled and of the observed concentration data by plotting their quantiles against each other. If the two distributions are similar, the points in the Q-Q plot will approximately lie on the 1:1 line. The two distributions are linearly related when the points lie along one line.

The CityChem model performs well for all pollutants in terms of linearity of the relation between modelled and observed concentration distributions of daily data at station $13 \mathrm{ST}$, except for the highest observed concentrations of $\mathrm{NO}_{2}, \mathrm{NO}$ and $\mathrm{O}_{3}$. The CityChem model has a tendency to underestimate observed $\mathrm{PM}_{2.5}$ and $\mathrm{PM}_{10}$ in the high concentration range. Observed $\mathrm{SO}_{2}$ daily means are underestimated by a factor of 2 .

Levels of $\mathrm{PM}_{2.5}$ and $\mathrm{PM}_{10}$ in the model are controlled by primary emission of particulate matter and their atmospheric dispersion. Dry deposition is negligible on the urban scale and secondary aerosol formation is not taken into account in the model. The comparison of the time series of daily mean concentrations at the inner-city urban background station 13ST 
Geosci. Model Dev. Discuss., https://doi.org/10.5194/gmd-2018-8

Manuscript under review for journal Geosci. Model Dev.

Discussion started: 24 January 2018

(c) Author(s) 2018. CC BY 4.0 License.

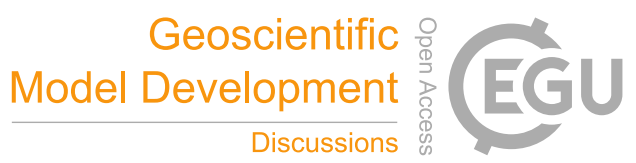

in Fig. 10 indicates, that the underestimation of $\mathrm{PM}_{2.5}$ and $\mathrm{PM}_{10}$ by CityChem model occurs throughout the winter season (November - February).

Inspection of the time series comparison reveals that modelled $\mathrm{O}_{3}$ concentrations (maximum of the daily 8-hour running mean) are too low in summer but not during the remaining year. Further, modelled daily concentrations of $\mathrm{NO}_{2}$ and $\mathrm{NO}$ frequently show higher concentrations during summer than observed.

Statistical performance analysis (Table 6-8) provides insight on the model performance in general; but it does not tell whether the model results have reached a sufficient level of quality for a given policy support application. For the FAIRMODE DELTA Tool, the model quality objective has been constructed on the basis of the observation uncertainty and describes the minimum level of quality to be achieved by a model to be fit for policy use (Thunis et al., 2012a, 2013; Pernigotti et al., 2013). The model quality indicator (MQI) is based on the RMSE and provides a general overview of the model performance. The associated model performance criteria (MPC) for correlation, standard deviation and bias can be used to highlight which of the model performance aspects need to be improved. Details on the MQI and MPC are given in Appendix B.

Figure 11 shows the model performance evaluation of CityChem in terms of fitness for purpose in form of scatter diagram and Target diagram (Thunis et al., 2012a) for $\mathrm{NO}_{2}$ (hourly), $\mathrm{O}_{3}$ (daily max. of the 8-h running mean) and $\mathrm{PM}_{10}$ (daily mean). For the yearly averaged values shown in the scatter diagrams, the model quality objective is the bias MPC (as defined by Eq. (B13)). The green-shaded area in the scatter and Target diagram is the MPC fulfilment zone. The orange-shaded area still indicates fulfilment but the error is dominated by the MPC criteria (here: bias). The part of the green-shaded area within the dashed lines is the zone where the difference between model and observation lies within the measurement uncertainty range.

The scatter diagrams related to the bias MPC (Fig. 11a-c) for yearly averaged $\mathrm{NO}_{2}$ and $\mathrm{O}_{3}$ indicate fulfilment for all stations, but at 2 out of 14 stations the modelled $\mathrm{NO}_{2}$ concentrations are biased. For yearly averaged $\mathrm{PM}_{10}, 5$ out of 9 stations are found in the green-shaded zone; 3 in the orange-shaded zone and one station (61WB) is outside the MPC fulfilment range.

In the right quadrant of the Target diagram (Fig. 11d-f), the error related to standard deviation dominates the model performance and in the left quadrant the error related to correlation dominates the model performance. In the top quadrant, bias is positive and in the bottom quadrant bias is negative. The green-shaded zone identifies the fulfilment of the RMSE criteria as defined by Eq. (B11). The performance criterion for the target indicator is set to unity (circle limit) regardless of spatial scale and pollutant and it is expected to be fulfilled by at least $90 \%$ of the available stations.

The CityChem model fulfils the model performance objectives for $\mathrm{O}_{3}$ (daily max. of the 8-h running mean) both in terms of bias MPC and MQI (max. MQI = 0.727). The model performance for $\mathrm{NO}_{2}$ (hourly) is deteriorated due to the relatively poor temporal correlation, as seen from the Target diagram. CityChem somewhat exceeds the MQI of unity (max. MQI = 1.18) but it is expected that the model can be improved to fulfil the performance objectives. For $\mathrm{PM}_{10}$ (daily mean) the CityChem model shows weak performance (max. MQI $=1.51$ ), mainly related to the centred RMSE (abscissa of the Target diagram). CityChem performs worst for $\mathrm{PM}_{10}$ at traffic stations (largest distance from origin in Target diagram). Further analysis indicated that the poor correlation is due to underestimation of $\mathrm{PM}_{10}$ in winter combined with an overestimation of the weekdays-weekend difference by the model. 
Geosci. Model Dev. Discuss., https://doi.org/10.5194/gmd-2018-8

Manuscript under review for journal Geosci. Model Dev.

Discussion started: 24 January 2018

(c) Author(s) 2018. CC BY 4.0 License.

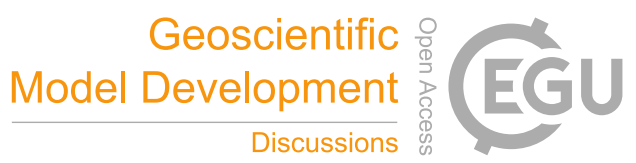

\subsection{Atmospheric chemistry in the urban area}

The atmospheric chemistry is complex in urban environments, due to the large temporal, spatial and compositional variations of the input from anthropogenic emissions of $\mathrm{NO}_{\mathrm{X}}, \mathrm{NMVOC}$ and $\mathrm{CO}$ in the urban area (Sillman, 1999). Figure 12 depicts spatial maps of the annual mean concentrations of $\mathrm{NO}_{2}, \mathrm{O}_{3}$, total $\mathrm{NMVOC}, \mathrm{SO}_{2}$, gaseous sulphuric acid $\left(\mathrm{H}_{2} \mathrm{SO}_{4}\right)$ and $\mathrm{PM}_{2.5}$ from the model output of the receptor grid (resolution $100 \times 100 \mathrm{~m}^{2}$ ). With the exception of $\mathrm{PM}_{2.5}$, concentrations of aforementioned compounds are modulated by photochemical reactions in the model simulation.

Prevailing winds from west allow for a simplified view of the inflow-outflow pattern for ozone within the study domain of Hamburg, on annual average. Following the inflow-outflow direction in space from west to east $(30 \mathrm{~km})$, modelled $\mathrm{O}_{3}$ concentration starts with ca. $50 \mu \mathrm{g} \mathrm{m}^{-3}$ at the western border, largely reduces in the inner-city to $10-30 \mu \mathrm{g} \mathrm{m}^{-3}$ and over the eastern part gradually increases to ca. $40 \mu \mathrm{g} \mathrm{m}^{-3}$. Modelled $\mathrm{O}_{3}$ at the outflow border does not reach the level at the inflow border. Within the urban area, the traffic-related emissions of $\mathrm{NO}$ destroy much of the $\mathrm{O}_{3}$ (mainly at night when $\mathrm{O}_{3}$ is not recycled through photolysis of $\mathrm{NO}_{2}$ ), clearly seen as minimum concentrations along the traffic network. Thus, the inner urban area provides an efficient sink for ozone, which qualitatively is in accord with findings of the REPARTEE (Regents Park and Tower Environmental Experiment) measurement campaign carried out in London in the autumn of 2006 and 2007 (Harrison et al., 2012).

Photochemical production of $\mathrm{O}_{3}$ from $\mathrm{NO}_{\mathrm{X}}, \mathrm{NMVOC}$ and $\mathrm{CO}$, emitted in the urban area, is very limited in the inner-city. Main sources of NMVOC in Hamburg are solvent use (SNAP cat. 06) and traffic emissions. NMVOC annual mean concentrations of more than $160 \mu \mathrm{g} \mathrm{m}^{-3}$ were modelled close to roads in the inner-city (Fig. 12c). The loss of NMVOC by OH-initiated oxidation in the model is inhibited due to the low $\mathrm{O}_{3}$ concentrations in the inner-city. In summer, modelled OH midday maximum concentrations are in the range $(0.5-2) \times 10^{6}$ molecule $\mathrm{cm}^{-3}$ in the inner-city. Modelled o-xylene, which is the model surrogate compound for the sum of aromatic VOC is ca. $60 \mu \mathrm{g} \mathrm{m}^{-3}$ (13 ppbv), in some distance from the roads. This value is several times higher than indicated by ambient measurements. For instance, mixing ratios for the sum of aromatics in the order of 2 ppbv have been measured in central London (Valach et al., 2015). This points to an overestimation of the NMVOC emissions from traffic line sources for Hamburg.

$\mathrm{SO}_{2}$ is an important precursor for secondary aerosol formation. $\mathrm{SO}_{2}$ emissions in Hamburg are mainly from industrial point sources and ship traffic in the harbour area. Highest yearly averaged modelled $\mathrm{SO}_{2}$ concentrations are in the range of $20-45 \mu \mathrm{g} \mathrm{m}^{-3}$; in proximity of the main sources of $\mathrm{SO}_{2}$ (Fig. 12d).

In the atmosphere, $\mathrm{SO}_{2}$ reacts with the $\mathrm{OH}$ radical and with $\mathrm{CH}_{3} \mathrm{O}_{2}$ to give gaseous sulphuric acid $\left(\mathrm{H}_{2} \mathrm{SO}_{4}\right)$. Both reactions are included in the "CC45" chemical mechanism. The presence of sulphuric acid in gaseous concentrations of $10^{6}-$ $10^{7}$ molecule $\mathrm{cm}^{-3}$ is necessary in order to observe new particle formation events in the atmosphere (Zhang et al., 2012). In the model, a constant very low BCON value $\left(10^{-5} \mu \mathrm{g} \mathrm{m}^{-3}\right)$ was chosen for $\mathrm{H}_{2} \mathrm{SO}_{4}$, leading to reduced sulphuric acid concentration in the boundary cells (Fig. 12e). Towards the inner domain, $\mathrm{H}_{2} \mathrm{SO}_{4}$ quickly increases due to the oxidation of $\mathrm{SO}_{2}$ advected to Hamburg from the regional background. Modelled annual mean $\mathrm{H}_{2} \mathrm{SO}_{4}$ peaks in the harbour area with up to $0.02 \mu \mathrm{g} \mathrm{m}^{-3}$. On spatial average, $\mathrm{H}_{2} \mathrm{SO}_{4}$ annual mean concentration is $0.014 \mu \mathrm{g} \mathrm{m}^{-3}$, corresponding to $8.6 \times 10^{7}$ molecule $\mathrm{cm}^{-3}$, higher than 
Geosci. Model Dev. Discuss., https://doi.org/10.5194/gmd-2018-8

Manuscript under review for journal Geosci. Model Dev.

Discussion started: 24 January 2018

(c) Author(s) 2018. CC BY 4.0 License.

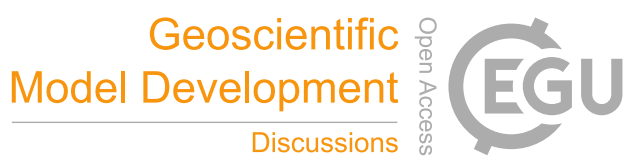

typical ambient concentrations in the urban atmosphere. For comparison, reported maximum midday $\mathrm{H}_{2} \mathrm{SO}_{4}$ concentrations in Beijing are in the range $(0.31-1.1) \times 10^{7}$ molecule $\mathrm{cm}^{-3}$ (Wang et al., 2013). Too high modelled $\mathrm{H}_{2} \mathrm{SO}_{4}$ is explained by the fact that condensation of sulphuric acid on pre-existing particles is not accounted for in the model. Condensation is the most important atmospheric sink of sulphuric acid and also leads to the formation of particulate sulphate.

$\mathrm{PM}_{2.5}$ in the urban background is to a large extent controlled by the atmospheric transport from up-wind regions (Beekmann et al., 2015). Modelled $\mathrm{PM}_{2.5}$ levels in the urban background of Hamburg are on annual average $2.5 \mu \mathrm{g} \mathrm{m}^{-3}$ higher than the regional background. The urban increment due to road traffic exceeds the urban background by $15-30 \mu \mathrm{g} \mathrm{m}^{-3}$ in the model simulation (Fig. 12f).

Annual mean concentrations of regulatory air pollutants from CityChem model output were compared to the available observation data (Fig. 13). The CityChem model reproduces the spatial variation of $\mathrm{NO}_{2}$ and $\mathrm{NO}$ concentrations (Fig. 13a-b) and the concentration gradients of $\mathrm{NO}_{2}$ and $\mathrm{NO}$ between the urban background (80KT, 51BF, 52NG, 13ST; 61WB, 54BL, 27TA, 74BT), traffic stations (68HB, 64KS, 70MB, 17SM) and industrial stations (21BI, 20VE). For most stations, annual mean of modelled and observed $\mathrm{NO}_{2}$ are in agreement. Observed annual mean $\mathrm{NO}_{2}$ is overestimated by the model at two urban background stations (74BT and 80KT) by about $60 \%$. For the same stations, observed NO is overestimated by a factor of 2.5. Modelled and observed annual mean $\mathrm{NO}_{2}$ at the four traffic stations exceed the annual limit value of $40 \mu \mathrm{g} \mathrm{m}^{-3}$. The model simulation suggests that there is wide-spread exceedance of this limit value in the city, mainly at the main streets and the crossroads of the inner-city and along the motorways (Fig. 12a)

Annual mean $\mathrm{SO}_{2}$ was compared at five stations (Fig. 13d). With the exception of the industrial station 20VE, modelled annual mean $\mathrm{SO}_{2}$ was within $40 \%$ of the observed concentrations. At station $20 \mathrm{VE}$, modelled $\mathrm{SO}_{2}$ is about two times higher than observed $\mathrm{SO}_{2}$. Obviously the model overestimated the influence of $\mathrm{SO}_{2}$ emissions from nearby industrial sources.

For the stations $20 \mathrm{VE}$ and $61 \mathrm{WB}$, modelled annual means of $\mathrm{PM}_{2.5}$ and $\mathrm{PM}_{10}$ are considerably lower than the observed annual means (Fig. 13e-f). Observed $\mathrm{PM}_{10}$ at these stations is underestimated by approximately the same magnitude as $\mathrm{PM}_{2.5}$, indicating that the missing PM is in the fine fraction. The discrepancy is highest for 61WB (Wilhelmsburg) which is located in a densely populated on the east side of the harbour area. The main contribution of emissions from shipping activity in the port area to ambient concentrations of $\mathrm{NO}_{2}$ and $\mathrm{PM}_{2.5}$ in Hamburg is primarily located in the southwest part of the city (Ramacher et al., 2018). Secondary formation of sulphate originating from oxidation of ship-emitted $\mathrm{SO}_{2}$ may play a role at station 61WB (Aulinger et al., 2017). Tower measurements in London during REPARTEE (Harrison et al., 2012) gave clear indication that the sulphate concentrations measured at ground level were controlled by the regionally transported sulphate. In contrast, CityChem results suggest that significant secondary formation of sulphate might take place in the harbour area of Hamburg, showing the need for further investigation.

Observed levels of annual mean $\mathrm{O}_{3}$ at the five urban background stations (13ST, 27TA, 51BF, 54BL, 52NG) are captured by the model within $30 \%$ (Fig. 13c). The winter mean of modelled $\mathrm{O}_{3}$ is ca. $50 \%$ higher than the observed at stations 27TA, 54BL and 52NG. The summer mean of modelled $\mathrm{O}_{3}$ is lower than the observed at station $13 \mathrm{ST}$ (by $28 \%$ ) but in fair agreement with the observed for the other stations. Possible explanations for the underestimation of ozone in summer in the inner-city are: (1) missing emissions of biogenic VOC (BVOC) from trees in urban green parks and at roadside; (2) advection of $\mathrm{NO}_{\mathrm{X}}$ 
Geosci. Model Dev. Discuss., https://doi.org/10.5194/gmd-2018-8

Manuscript under review for journal Geosci. Model Dev.

Discussion started: 24 January 2018

(c) Author(s) 2018. CC BY 4.0 License.

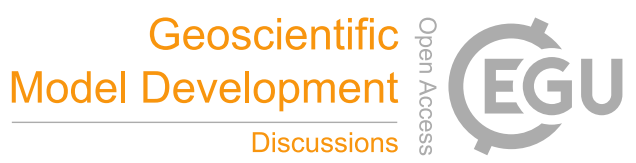

concentration peaks through the domain border; (3) too high emissions of $\mathrm{NO}_{\mathrm{X}}$ from local road traffic; and (4) shortcomings of the parameterisation of the photochemical reaction cycle of ozone in the model. Explanation (2) and (3) are related to the titration of $\mathrm{O}_{3}$ by reaction with $\mathrm{NO}$ at night. Explanation (1) is based on the finding, that isoprene, in the presence of sufficiently high level of $\mathrm{NO}_{\mathrm{X}}$, can contribute substantially to the $\mathrm{O}_{3}$ formation in the urban atmosphere. Many urban trees such as European aspen (Populus) and deciduous oaks emit large amounts of isoprene (Karl et al., 2009). The ozone formation potential of BVOC emitted from urban trees is sufficiently high to outperform the ozone uptake capacity of the trees (Grote et al., 2016). Emissions of isoprene and monoterpenes are not implemented in the current version of CityChem.

A 5-day episode with high ozone in July 2012 was analysed. Fig. 14 shows the $\mathrm{O}_{3}, \mathrm{NO}_{2}$ and $\mathrm{OH}$ concentrations and total solar radiation during the episode as function of time at station 54BL close to western border (Fig. 14a), inner-city station 13ST (Fig. 14b) and station 27TA in the eastern part of Hamburg (Fig. 14c). Four short time periods P1 - P4 with $\mathrm{O}_{3}$ underestimation by the model at station 13ST were identified (grey-shaded area). The modelled $\mathrm{OH}$ is controlled by the diurnal variation of total solar radiation with the highest $\mathrm{OH}$ concentration close to local solar noon in the range $(8-19) \times 10^{6}$ molecule $\mathrm{cm}^{-3}$ at $54 \mathrm{BL}$ and in the range $(0.5-6) \times 10^{6}$ molecule $\mathrm{cm}^{-3}$ at 13ST and 27TA. Total solar radiation predicted by the model agreed fairly well with the observations during the ozone episode.

Wind was from southeast during the episode; but changed to northwest for the duration of the night from the second to third day (period P1). A sudden drop of $\mathrm{O}_{3}$ during this night can be noted at 54BL. The wind direction change was not reproduced by the model. Modelled $\mathrm{O}_{3}$ was higher than observed at 27TA during P1. At 13ST observed $\mathrm{O}_{3}$ is reduced by ca. $70 \mu \mathrm{g} \mathrm{m}^{-3}$ compared to the maximum of the previous day. CityChem predicts much higher $\mathrm{NO}_{2}$ and too low $\mathrm{O}_{3}$ during P1. The modelled nocturnal BL was very shallow with a mixing height $\left(h_{m i x}\right)$ of ca. $30 \mathrm{~m}$. As a consequence the model predicted too high accumulation of $\mathrm{NO}_{\mathrm{X}}$ in the surface layer.

CityChem underestimates observed $\mathrm{O}_{3}$ during the night period $\mathrm{P} 2$ by ca. $50 \mu \mathrm{g} \mathrm{m}^{-3}$ at all stations. In the simulation, high $\mathrm{NO}_{\mathrm{X}}$ is advected through the eastern border of the domain leading to the titration of ozone and higher than observed $\mathrm{NO}_{2}$ concentrations. Modelled $h_{m i x}$ was similar low as during P1.

During night period P3, CityChem underestimates observed $\mathrm{O}_{3}$ by $40 \mu \mathrm{g} \mathrm{m}^{-3}$ at $13 \mathrm{ST}$, but not at the other stations. Modelled $h_{\text {mix }}$ was about $150 \mathrm{~m}$, higher than during P1 and P2. Modelled $\mathrm{NO}_{2}$ at $13 \mathrm{ST}$ was much higher than observed, possibly due to too high emissions of $\mathrm{NO}_{\mathrm{X}}$ in the inner-city at night.

$\mathrm{P} 4$ is a daytime period with observed maximum $\mathrm{O}_{3}$ at noon in the range $80-90 \mu \mathrm{g} \mathrm{m}^{-3}$ at all stations. CityChem underestimates the noon maximum by $24 \%$ at $27 \mathrm{TA}$ and by $47 \%$ at $13 \mathrm{ST}$. Total solar radiation at noon in the simulation was $30 \%$ lower than the observations at 27TA and 13ST. TAPM has difficulties with accurately reproducing situations with increased cloud coverage (see Sect. 4.1).

The diurnal variation of $\mathrm{O}_{3}$ and $\mathrm{NO}_{2}$ in summer (JJA) and autumn (SON) at station 13ST was evaluated (Fig. 16). The daily cycle of observed median $\mathrm{O}_{3}$ in summer shows a clear minimum in the early morning hours (between 4 and 7 a.m. local time). At the same time, observed median $\mathrm{NO}_{2}$ shows the daily maximum. Between noon and 10 p.m. modelled median $\mathrm{O}_{3}$ is below the band width of observed ozone (25th to 75th percentile). This coincides with modelled median $\mathrm{NO}_{2}$ being higher than observed. Summer is the season with the highest photochemical activity. Tropospheric ozone formation is largely controlled 
Geosci. Model Dev. Discuss., https://doi.org/10.5194/gmd-2018-8

Manuscript under review for journal Geosci. Model Dev.

Discussion started: 24 January 2018

(c) Author(s) 2018. CC BY 4.0 License.

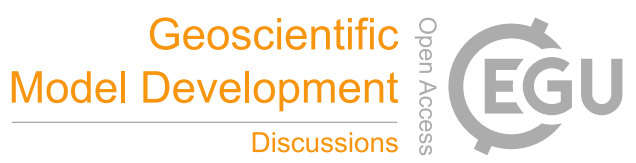

(c) (i)

by the fast photolysis of $\mathrm{NO}_{2}$ (Crutzen and Lelieveld, 2011). An immediate explanation for the discrepancy in the daily cycle of $\mathrm{O}_{3}$ and $\mathrm{NO}_{2}$ is thus the inaccuracy of the modelled $\mathrm{NO}_{2}$ photo-dissociation coefficient, $J_{\mathrm{NO}_{2}}$. The model-calculated $J_{\mathrm{NO}_{2}}$ value depends on the solar zenith angle and cloud fraction. $J_{\mathrm{NO}_{2}}$ might also depend on the aerosol load, but Trebs et al. (2009) only found minor differences between $J_{\mathrm{NO}_{2}}$ values measured at locations with extremely different aerosol load (polluted air, mountain site).

Hence, the cloud correction factor (Eq. (7)) used in the photo-dissociation parameterisation might be too strong, i.e. reducing $J_{\mathrm{NO}_{2}}$ too much as function of increasing cloud cover. In contrast, it has been reported that the photolysis of $\mathrm{NO}_{2}$ can be considerably decreased (by $40 \%$ compared to open areas) within street canyons (Koepke et al., 2010) because incoming direct and diffuse sun light at large zenith angles may be obstructed by the buildings. Koepke et al. (2010) suggest the application of a scaling factor of 0.5 to adjust $J_{\mathrm{NO}_{2}}$ from a free horizon to street canyons.

In autumn, the daily cycle of observed median $\mathrm{O}_{3}$ shows a minimum at 6-8 a.m. and at 6-8 p.m., coinciding with the two maxima of observed median $\mathrm{NO}_{2}$. The daily cycle relates to $\mathrm{NO}_{\mathrm{X}}$-emissions during the traffic rush hours in the morning and the evening. Between midnight and 6 a.m. modelled median $\mathrm{O}_{3}$ is above and modelled median $\mathrm{NO}_{2}$ is below the band width of observations. This indicates a too low frequency of stable conditions at night in the model. A more stable stratification of the nocturnal BL as achieved with the standard $K^{(z)}$-method might be more adequate for model simulation in autumn.

\subsection{Traffic stations}

A test run with the simplified street canyon model (SSCM; see Sect. 2.2) activated was performed for January 2012 and compared to the reference simulation. Due to low insolation and an average wind speed of $3-4 \mathrm{~m} \mathrm{~s}^{-1}$ it is expected that the photochemical steady state assumption was fulfilled. A period of 16 days was analysed at the four traffic stations. Wind was from northwest to west in the first 8 days, but then changed to eastern directions. The wind direction change was reproduced by TAPM, but occurs with a delay of three days in the model. Based on the modelled wind direction, the traffic station was either on the leeward side (grey-shaded area in Fig. 15) or the windward side of the street canyon.

For station 17SM, the $\mathrm{NO}_{2}$ concentration time series computed using SSCM followed closely the reference simulation (Fig. 15a; upper part). Deviations from the reference simulation are within 25\%. Station 17SM is located at a street oriented from southeast to northwest. The station was on the windward side (according to modelled wind direction) during the most time of the study period and modelled wind direction was frequently parallel or near parallel to the street axis.

For station 64KS, modelled $\mathrm{NO}_{2}$ concentrations using SSCM were close to the reference simulation. $\mathrm{NO}_{2}$ concentrations with SSCM were about $20 \%$ higher than the reference during days with leeward position (Fig. 15a; lower part). The leeward side is influenced directly by the traffic emissions in the street; in addition to the recirculated polluted air and the urban background air. While SSCM takes all contributions into account, HIWAY-2 neglects the contribution of recirculated polluted air. On the days when 64KS was on the windward side (24-29 Jan. 2012) both line source models consistently overestimate observed $\mathrm{NO}_{2}$ by a factor of two or more. The same is found for 17SM on 16, 17, and 20 January. Stations 17SM and 64KS are located in narrow street canyons with compact building rows on both sides. For narrow street canyons, it is likely that the recirculation zone extends through the whole canyon; in which case no direct contribution should be attributed to the windward 
Geosci. Model Dev. Discuss., https://doi.org/10.5194/gmd-2018-8

Manuscript under review for journal Geosci. Model Dev.

Discussion started: 24 January 2018

(c) Author(s) 2018. CC BY 4.0 License.

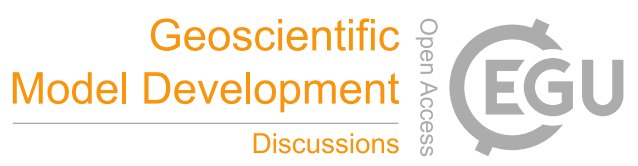

(c) (i)

station. In SSCM, a direct contribution is added when the length of the recirculation zone is smaller than the canyon width. Both dimensions are only roughly estimated in SSCM because it considers only generic street canyon types and not the site-specific street canyon geometry.

Largest deviations between SSCM and the reference simulation were found for station 68HB (Fig. 15b; upper part). Station $68 \mathrm{HB}$ is located in front of a building row of a wide 4-lane street canyon; with gaps between buildings on the opposite site. The street canyon is oriented from southeast to northwest. During 8 days, modelled $\mathrm{NO}_{2}$ with $\mathrm{SSCM}_{\text {was }}>50 \%$ higher than in the reference simulation. This can be attributed to the calculated high direct contribution. The direct contribution in SSCM is mainly sensitive to the emission intensity of the line source, the street level wind speed and the maximum integration path (see Sect. S4).

Station 70MB is located on the tree stripe in the middle between 2-lane streets in each direction, in a dense-built street canyon. Since the street is modelled as two parallel line sources, the station only receives direct contribution from one of the line sources at a given time. The street canyon is oriented from southwest to northeast and thus the station was frequently on the leeward side. SSCM fits the observed $\mathrm{NO}_{2}$ concentration better on 6 days (Fig. 15b; upper part), while it gave concentrations that corresponded to the reference for all other days.

\section{Planned improvements}

This paper presents results from the first public domain-release of CityChem (version 1.0). The development of CityChem is still in its beginning and will continue in the coming years. Four areas of need for improvement have been identified in the present study: (1) dry and wet deposition fluxes; (2) treatment of photochemistry in the urban atmosphere; (3) formation of secondary inorganic aerosol (SIA); and (4) formation of biogenic and anthropogenic secondary organic aerosol (SOA). In urban air quality models, the degree of detail for the implementation of new physical-chemical processes is restricted by the intention to minimise the computational burden and to preserve the model's practicability for use in policy applications (Mensink et al., 2005). Largest computational costs in 3-D air quality models are commonly associated with the introduction of new reactive chemical species that have to be advected and with the SOA formation scheme.

Specifically, the implementation of the following processes and output data is planned for the next versions of CityChem:

1. Computation of dry and wet deposition fluxes on the Eulerian grid in urban areas and output of 2-D surface fields of hourly accumulated dry deposition and wet deposition. Canopy resistance $\left(R_{c}\right)$ for gases, i.e. the sticking between the surface and the gas once the gas has collided with the surface, needs to be refined. Tabulated $R_{c}$ values of various gases for the TAPM land use classes could be compiled, beginning with the non-vegetated surfaces, such as building materials (e.g., Behlen et al., 2008). For vegetated surface, information of the leaf area index (LAI) and the stomatal resistance is required to compute $R_{c}$ with the deposition model of Wesely et al. (1989). Wet scavenging treatment can be improved by extracting cloud base information from TAPM or by using a cloud base parameterisation(e.g., Asman, 1995). 
Geosci. Model Dev. Discuss., https://doi.org/10.5194/gmd-2018-8

Manuscript under review for journal Geosci. Model Dev.

Discussion started: 24 January 2018

(c) Author(s) 2018. CC BY 4.0 License.

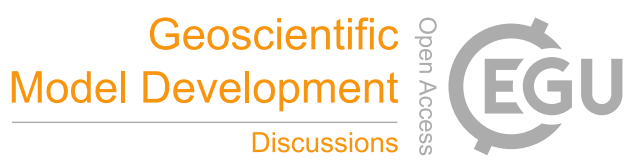

2. Use of a more detailed chemistry scheme at the receptor points together with the modified TWOSTEP solver. The photochemical steady-state relationship is usually not valid in urban air because organic peroxy radicals compete with $\mathrm{O}_{3}$ to convert $\mathrm{NO}$ to $\mathrm{NO}_{2}$. The parameterisation for the calculation of photo-dissociation coefficients needs to be revised in order to better capture the photolysis frequency of $\mathrm{NO}_{2}$ in the urban environment. In the sub-urban and rural areas of the city domain levels of $\mathrm{NO}_{\mathrm{X}}$ are often low (1 ppbv or less). Thus, the chemistry scheme "CC45" needs to be extended to take into account $\mathrm{RO}_{2}+\mathrm{RO}_{2}$ reactions (Sect. 3.3) of the hydrocarbons with highest attribution in the NMVOC emission split (aromatics and alkanes with $>3$ carbon atoms). Further, biogenic monoterpenes (represented by $\alpha$-pinene) need to be included because they are a relevant source of $\mathrm{RO}_{2}$ at night (Platt et al., 2002).

3. At present, the chemical composition of the fine and coarse particles in CityChem is not chemically-speciated. The main focus is on formation of particulate sulphate $\left(\mathrm{SO}_{4}^{2-}\right)$, ammonium $\left(\mathrm{NH}_{4}^{+}\right)$and nitrate $\left(\mathrm{NO}_{3}^{-}\right)$. Thus, the thermodynamic equilibrium solver MARS (Binkowski and Shankar, 1995) could be used for the calculation of the partitioning between gas and fine-mode particles (Simpson et al., 2012). However, MARS does not account for mineral dust components and sea salt; the latter could be relevant for SIA formation in coastal cities because it increases the water associated with PM.

4. Use of a volatility basis set (VBS) approach (Donahue et al., 2009) for computing the formation of SOA. A VBS with 4 or 5 volatility bins appears to be sufficient given the great uncertainty associated with the emission of semi-volatility (SVOC) and intermediate-volatility volatile organic compounds (IVOC) from road traffic (Zhao et al., 2015) and the saturation vapour pressure of these compounds. Traffic emissions of PM will be separated into (non-volatile) primary organic aerosol (POA) and elemental carbon (EC), implicitly assuming irreversible condensation of SVOC and IVOC to the exhaust PM. It is expected that this approach will lead to higher organic PM in urban areas with high traffic density compared to a SOA model that allows for evaporation of primary emitted organic compounds. A clear advantage of the approach is that it avoids the need for discounting SVOC and IVOC from the city's PM emission inventory. Emissions of isoprene and monoterpenes from urban trees will be required for biogenic SOA. Adequate land use data for urban green areas mapped to TAPM land use classes or a plant-specific BVOC emission inventory (Karl et al., 2009) on the city-scale for in-line computation of BVOC emissions.

On a longer time perspective, the MAFOR aerosol dynamics solver (Karl et al., 2011; Karl et al., 2016) will be implemented which can be used as additional option to compute SIA and SOA together with the information on the size distribution of ultrafine particles (UFP) and the total PN.

\section{Conclusions}

The City-scale Chemistry (CityChem) model is an extension of the urban dispersion model EPISODE (Slørdal et al., 2003, 2008) with the aim to enable chemistry/transport simulations of multiple reactive pollutants on urban scales. The new model is called CityChem-EPISODE. It systematically combines a 3-D Eulerian grid model component with sub-grid Gaussian dispersion model components for a fully consistent computation of pollutant concentrations near road traffic line sources and 
Geosci. Model Dev. Discuss., https://doi.org/10.5194/gmd-2018-8

Manuscript under review for journal Geosci. Model Dev.

Discussion started: 24 January 2018

(c) Author(s) 2018. CC BY 4.0 License.

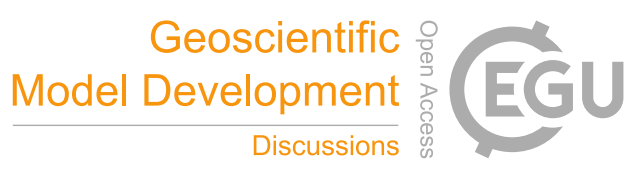

industrial point sources with high spatial resolution for the entire study domain. The CityChem-EPISODE model takes into account that long-range transport contributes to urban pollutant levels by using hourly varying pollutant concentrations at the lateral and vertical boundaries from the CMAQ model (Byun and Schere, 2006) as initial and boundary concentrations. The model reads meteorological fields generated by the prognostic meteorology component of TAPM (Hurley, 2008; Hurley et al.,

5 2005) but can also use meteorological fields constrained by observations. The performance of the new model was evaluated with a series of synthetic tests to study the basic functionalities and with a first application to the air quality situation in the city of Hamburg, Germany.

Modelling with CityChem-EPISODE focuses on ozone formation. Ozone is produced in photochemical reaction cycles from the precursors $\mathrm{NO}_{\mathrm{X}}$ and VOC that are emitted by various anthropogenic activities in the urban area. The model performs fairly well for ozone in terms of temporal correlation and bias at the AQ monitoring stations in Hamburg. It fulfils the model performance objectives for $\mathrm{O}_{3}$ (daily max. of the 8-h running mean) both in terms of the bias MPC and the model quality indicator. In summer afternoons, when photochemical activity is highest, modelled median $\mathrm{O}_{3}$ at an inner-city urban background station was about $30 \%$ lower than the observed median $\mathrm{O}_{3}$. Inaccuracy of the computed photolysis frequency of $\mathrm{NO}_{2}$ is the most probable explanation for this. An update of the photolysis frequency will also affect modelled $\mathrm{NO}_{2}$ concentrations in summer.

The CityChem-EPISODE model reproduces the spatial variation of annual mean $\mathrm{NO}_{2}$ and $\mathrm{NO}$ concentrations between urban background, traffic and industrial stations. The model fulfils the bias MPC for yearly averaged $\mathrm{NO}_{2}$ concentrations. However, the temporal correlation between modelled and observed hourly $\mathrm{NO}_{2}$ concentrations is weak for some of the stations.

For daily mean $\mathrm{PM}_{10}$, the performance of CityChem-EPISODE is moderate due to low temporal correlation. The low correlation is linked to uncertainties in the seasonal cycle of the anthropogenic PM emissions within the urban area. Missing emissions from domestic heating might be an explanation for the too low modelled $\mathrm{PM}_{10}$ in winter months. The model performed worst for daily mean $\mathrm{PM}_{10}$ at the traffic stations.

Uncertainty in the anthropogenic emission inventory is one of the main sources of uncertainty in air quality modelling; the accuracy of emissions depends on the quality of the underlying input proxy data (population density, household units, vehicle number, etc.) and the choice of the emission factors (Guevara et al., 2016). The applied daily, weekly and seasonal temporal profiles are also uncertain. In the case of domestic heating (SNAP cat. 02) emissions of $\mathrm{PM}_{2.5}$ and $\mathrm{PM}_{10}$, uncertainties are related to the energy type, the emission factors and the temporal profile. Taking into account the dependency of heating on the daily air temperature would give a more realistic seasonal variation of domestic heating emissions.

Occasionally modelled high concentration values of $\mathrm{NO}_{2}$ at night in summer were associated with a very shallow nocturnal BL that evolved due to the cooling of the surface. The BL height or mixing height, $h_{m i x}$ (which is the same when defined as the turbulent domain of the atmosphere adjacent to the ground), is a key parameter for air pollution models. In CityChemEPISODE, $h_{m i x}$ affects the calculation of the standard deviation of the horizontal wind fluctuations $\left(\sigma_{v}\right)$ and the vertical wind fluctuations $\left(\sigma_{w}\right)$ which are used for the plume dispersion in the point source sub-grid component; $\sigma_{v}$ also controls the horizontal eddy diffusivity in the Eulerian component. CityChem-EPISODE adopts the $h_{\text {mix }}$ values from the TAPM model. In stable conditions, TAPM defines $h_{m i x}$ as the first vertical model layer above the surface that has a vertical heat flux of less than $5 \%$ of the surface value, following Derbyshire (1990). This approach is reasonable because the heat fluxes will be small 
Geosci. Model Dev. Discuss., https://doi.org/10.5194/gmd-2018-8

Manuscript under review for journal Geosci. Model Dev.

Discussion started: 24 January 2018

(c) Author(s) 2018. CC BY 4.0 License.

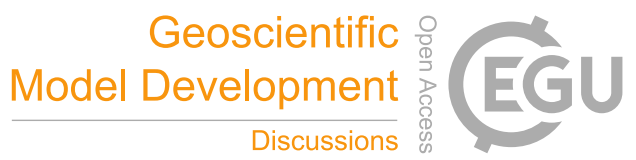

(c) (i)

above the surface inversion since the potential temperature gradient becomes small, while momentum flux may not become small (Vickers and Mahrt, 2004). There is still a need for verification studies of the different stable BL height parameterisations using comprehensive data sets (Seibert et al., 2000).

A simplified street canyon model (SSCM) based on the OSPM model (Berkowicz et al., 1997) is introduced, potentially

5 allowing for a better treatment of $\mathrm{NO}_{\mathrm{X}}$ at traffic stations. Emissions of $\mathrm{NO}_{\mathrm{X}}$ from road traffic dominate the urban $\mathrm{NO}_{2}$ levels in Hamburg for most months of the year, therefore improvements in the sub-grid line source component are expected to improve the overall performance of the model. At present, average building heights for three street canyon geometries in SSCM are based on the 3-D city model LoD1-DE Hamburg. Building heights in Hamburg may not be representative for other cities because buildings are limited to a certain height in the inner-city. SSCM needs to be refined in particular with respect to the calculation of the direct contribution from traffic emissions and a better representation of the street canyon geometry; for instance, by using spatially resolved data on building height and street canyon width. Overall, SSCM has the potential to improve the prediction for the leeward receptors because it takes into account the recirculation contribution.

Envisaged applications of the CityChem-EPISODE model are urban air quality studies, environmental impact assessment, sensitivity analysis of sector-specific emission and the assessment of local and regional emission abatement policy options. Further development along the line of the planned improvements in Sect. 5 is expected to strengthen the model's adequacy for use in regulatory air quality assessment.

Code availability. The source codes of the CityChem-EPISODE model version 1.0 and the pre-processing utilities are accessible in release under the RPL license at http://doi.org/10.5281/zenodo.1116174 (Karl , 2017). A tar package with example data for a one month simulation and the User's Guide are included in the release. All pre-processing tools are written in FORTRAN. Software requirements for the utilities and the CityChem-EPISODE model are installation of the gcc/gfortran Fortran90 compiler (version 4.4. or later) and the netCDF library (version 3.6.0 or later).

Data availability. The following data sets are available for download from the HZG ftp server upon request:

- input data and output data for the synthetic tests;

- input data for the one-year AQ simulation of Hamburg (ca. 52 GB);

- DELTA Tool data for comparison of model output and measurements;

- model output data of the AQ simulation of Hamburg (ca. 100 GB).

\section{Appendix A: Treatment of deposition on the Eulerian grid}

The dry deposition of gases and aerosols is treated based on the resistance analogy, where the inverse deposition velocity of gases is the sum of three resistances in series, the aerodynamic resistance $R_{a}\left(\mathrm{~m} \mathrm{~s}^{-1}\right)$, the quasi-laminar layer resistance, 
Geosci. Model Dev. Discuss., https://doi.org/10.5194/gmd-2018-8

Manuscript under review for journal Geosci. Model Dev.

Discussion started: 24 January 2018

(c) Author(s) 2018. CC BY 4.0 License.

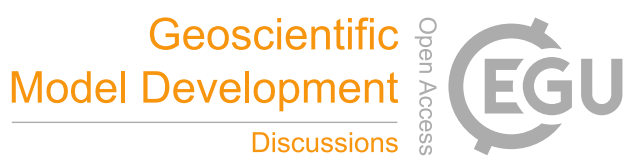

(c) (i)

$R_{b}\left(\mathrm{~m} \mathrm{~s}^{-1}\right)$, and the surface (canopy) resistance $R_{c}\left(\mathrm{~m} \mathrm{~s}^{-1}\right)$. Gravitational settling of coarse particles is taken into account for the dry deposition of aerosols. The loss rate of a gaseous species $i$ to the land or water surface, within a volume of unit area and height $\Delta z$ (here the thickness of the lowermost layer), is given by the product of the deposition velocity $V_{\mathrm{dry}}\left(\mathrm{m} \mathrm{s}^{-1}\right)$ at the reference height $z_{\text {ref }}$ (here the mid-point height of the lowermost model layer) and the concentration $\left(C_{i}\right)$ at that height:

$5 \frac{\Delta C_{i}\left(z_{\mathrm{ref}}\right)}{d t}=-V_{\mathrm{dry}} C_{i}\left(z_{\mathrm{ref}}\right) / \Delta z$,

The dry deposition velocity of gases, $V_{\mathrm{dry}, \mathrm{g}}$, is calculated as (Simpson et al., 2003):

$V_{\mathrm{dry}, \mathrm{g}}=\frac{1}{R_{a}+R_{b}+R c}$,

The aerodynamic resistance at $z_{\text {ref }}$ is calculated based on surface layer similarity theory as function of the Monin-Obukhov length and the friction velocity:

$R_{a}=\frac{1}{\kappa u_{*}}\left(\ln \frac{z_{\mathrm{ref}}}{z_{0}}-\Psi_{\mathrm{H}}\left(\frac{z_{\mathrm{ref}}}{L}\right)+\Psi_{\mathrm{H}}\left(\frac{z_{0}}{L}\right)\right)$,

where $\Psi_{H}$ is the influence function for heat transfer, $z_{0}$ is the surface roughness (for momentum) and $L$ is the Monin-Obukhov length. The quasi-laminar layer resistance is calculated according to the parameterisation given by Simpson et al. (2003). The canopy resistance, i.e. deposition due to capture of pollutants by the surface, is currently only considered by a minimum value, i.e. $R_{c}=R_{c, \min }=1 \mathrm{~m} \mathrm{~s}^{-1}$. The parameterisation of the canopy resistance is complex, since it depends both on surface characteristics and the chemical characteristics of the depositing gas.

The dry deposition velocity of particles, $V_{\text {dry,p }}$, is calculated as (Simpson et al., 2003):

$V_{\mathrm{dry}, \mathrm{p}}=\frac{1}{R_{a}+R_{b}+R_{a} R_{b} v_{s}}+v_{s}$,

where $v_{s}$ is the gravitational settling velocity and the other terms are as for gases.

Equation (A4) involves the assumption that all deposited particles stick to the surface, so that the surface resistance becomes zero. The dry deposition velocity of atmospheric aerosols depends on their sizes. The current formulation distinguishes between $\mathrm{PM}_{2.5}$ and $\mathrm{PM}_{10}$, which are presently assigned the particle diameters of $0.3 \mu \mathrm{m}$ and $4 \mu \mathrm{m}$. All the resistances are integrated over the aerosol sizes, assuming a log-normal particle size distribution with the geometric standard deviations of $2.0 \mu \mathrm{m}$ and $2.2 \mu \mathrm{m}$ for $\mathrm{PM}_{2.5}$ and $\mathrm{PM}_{10}$ respectively.

Wet deposition is described as a sink term within the advection/-diffusion equation and can be parameterized by $d C_{i} / d t=-\Lambda$. $C_{i}$; where $C_{i}$ is the grid concentration of a gaseous or particulate species and $\Lambda$ is the scavenging coefficient $\left(\mathrm{s}^{-1}\right)$. Wet scavenging is different from zero in grid cells where precipitation (rainfall or snowfall) occurs. The chosen crude approach for representing wet deposition treats in-cloud scavenging in the same way as below-cloud scavenging. Further, the cloud base is assumed to be at the model top, which means that scavenging occurs throughout the entire 1-D model column for which the precipitation rate in the surface grid cell is greater than zero. For the short-term estimation of near-ground concentrations in urban areas, below-cloud scavenging is expected to be the dominant wet removal process. A more accurate treatment of the below-cloud scavenging requires knowledge of the cloud base height (which is not standard output of the TAPM model) in 
Geosci. Model Dev. Discuss., https://doi.org/10.5194/gmd-2018-8

Manuscript under review for journal Geosci. Model Dev.

Discussion started: 24 January 2018

(c) Author(s) 2018. CC BY 4.0 License.

order to limit wet deposition to the model layers that are actually affected by raining clouds and to separate between in-cloud and below-cloud scavenging. The scavenging of gases is calculated as (Simpson et al., 2003):

$\Delta C_{i, \text { wet }}=-C_{i} \frac{W_{\text {sub }} P_{r}}{H_{\text {sub }}+\rho_{w}}$,

where $W_{\text {sub }}$ is the sub-cloud scavenging coefficient for gases, supplied as constant value by the model user, $P_{r}\left(\mathrm{~kg} \mathrm{~m}^{2} \mathrm{~s}^{-1}\right)$ is

5 the precipitation rate, $H_{\text {sub }}$ is the scavenging depth (corresponding to the total vertical depth of the model) and $\rho_{w}$ is the water density $\left(1000 \mathrm{~kg} \mathrm{~m}^{-3}\right)$.

Precipitation is a 2-D surface field, either from observations of precipitation rate or computed by TAPM. The wet deposition rate of particulate compounds is calculated as (Simpson et al., 2003):

$\Delta C_{i, \text { wet }}=-C_{i} \frac{A P_{r}}{V_{\mathrm{dr}}} \bar{E}$,

where $V_{\mathrm{dr}}$ is the raindrop fall speed $\left(V_{\mathrm{dr}}=5 \mathrm{~m} \mathrm{~s}^{-1}\right), A=5 \mathrm{~m}^{3} \mathrm{~kg}^{-1} \mathrm{~s}^{-1}$ is an empirical coefficient when the Marshall-Palmer size distribution is assumed for rain drops, and $\bar{E}$ is the tabulated size-dependent collection efficiency of aerosols by the rain drops.

\section{Appendix B: Statistical indicators and model performance indicators}

The statistical analysis of the model performance the following statistical indicators are used: overall bias (Bias), normalized mean bias (NMB), standard deviation (STD), root mean square error (RMSE), correlation coefficient (Corr) and index of agreement (IOA).

The overall bias captures the average deviations between the model and observed data and is defined as follows:

$\operatorname{Bias}=\bar{M}-\bar{O}$,

where $M$ and $O$ stand for the model and observation results, respectively. The overbars indicate the time average over $N$ time intervals (number of observations).

The normalized mean bias is given by:

$\mathrm{NMB}=\frac{\mathrm{Bias}}{\bar{O}}=\frac{\bar{M}-\bar{O}}{\bar{O}}$.

The root mean square error combines the magnitudes of the errors in predictions for various times into a single measure and is defined as:

$\mathrm{RMSE}=\sqrt{\frac{1}{N} \sum_{i=1}^{N}\left(M_{i}-O_{i}\right)^{2}}$,

where subscript $i$ indicates the time step (time of observation values). RMSE is a measure of accuracy, to compare prediction errors of different models for a particular data and not between datasets, as it is scale-dependent. 
Geosci. Model Dev. Discuss., https://doi.org/10.5194/gmd-2018-8

Manuscript under review for journal Geosci. Model Dev.

Discussion started: 24 January 2018

(c) Author(s) 2018. CC BY 4.0 License.

\section{(c) (1)}

The correlation coefficient (Pearson $r$ ) for the temporal correlation is defined as:

Corr $=r=\frac{\frac{1}{N} \sum_{i=1}^{N}\left(M_{i}-\bar{M}\right)\left(O_{i}-\bar{O}\right)}{\operatorname{STD}_{M} \operatorname{STD}_{O}}$.

$\mathrm{STD}_{M}$ and $\mathrm{STD}_{O}$ are the standard deviation of model and observation data, respectively. The standard deviations are:

$\operatorname{STD}_{M}=\sqrt{\frac{1}{N-1} \sum_{i=1}^{N}\left(M_{i}-\bar{M}\right)^{2}} \quad$ and

$5 \quad \operatorname{STD}_{O}=\sqrt{\frac{1}{N-1} \sum_{i=1}^{N}\left(O_{i}-\bar{O}\right)^{2}}$.

The index of agreement is defined as:

$\mathrm{IOA}=1-\frac{\sum_{i=1}^{N}\left(M_{i}-O_{i}\right)^{2}}{\sum_{i=1}^{N}\left(\left|M_{i}-\bar{M}\right|+\left|O_{i}-\bar{O}\right|\right)^{2}}$.

An IOA value close to 1 indicates agreement between modelled and observed data. The denominator in Eq. (B7) is referred to as the potential error.

The model performance criteria (MPC) for dispersion models is the minimum level of quality that has to be achieved for use in policy support related to AQ regulations. The MPC implemented in the FAIRMODE Delta Tool have been constructed on the basis of the observation uncertainty (Thunis et al., 2012a).

The uncertainty of a single observation value $U_{95}\left(O_{i}\right)$ is expressed as:

$U_{95}\left(O_{i}\right)=\mathrm{k} u_{r}^{\mathrm{RV}} \sqrt{\left(1-\alpha^{2}\right) O_{i}^{2}+\alpha^{2}(\mathrm{RV})^{2}}$,

where $u_{r}^{\mathrm{RV}}$ represents the relative measurement uncertainty estimated around a reference value, RV, for a given time averaging, e.g. the hourly or daily limit values of the Air Quality Directive (AQD). The fraction of uncertainty around the RV is given by $\alpha^{2}$. Most commonly, the expanded uncertainty is scaled by using a value of 2 for the coverage factor, $k$, to achieve a level of confidence of approximately 95 percent.

The root mean square of the observation uncertainty $\left(\mathrm{RMS}_{U}\right)$ is then:

$\operatorname{RMS}_{U}=\sqrt{\frac{1}{N} \sum_{i=1}^{N}\left(U_{95}\left(O_{i}\right)\right)^{2}}$

A model quality indicator (MQI) is defined as the ratio between the model-observation bias and a quantity proportional to the observation uncertainty as:

MQI $=\frac{\left|O_{i}-M_{i}\right|}{\beta U_{95}\left(O_{i}\right)}$,

with $\beta=2$ in the DELTA Tool. 
Geosci. Model Dev. Discuss., https://doi.org/10.5194/gmd-2018-8

Manuscript under review for journal Geosci. Model Dev.

Discussion started: 24 January 2018

(c) Author(s) 2018. CC BY 4.0 License.

Using Eq. (B9), the MQI can be generalized to a time series by:

$\mathrm{MQI}=\frac{\mathrm{RMSE}}{\beta \mathrm{RMS}_{U}} \leq 1$.

The model quality objective (MQO) is fulfilled when the MQI is less or equal 1.

A characteristic of the MQI is that errors in Bias, STDM and Corr are condensed into a single indicator value, as follows:

$5 \mathrm{MQI}^{2}=\frac{\mathrm{Bias}^{2}}{\left(\beta \mathrm{RMS}_{U}\right)^{2}}+\frac{\left(\mathrm{STD}_{M}-\mathrm{STD}_{O}\right)^{2}}{\left(\beta \mathrm{RMS}_{U}\right)^{2}}+\frac{2 \mathrm{STD}_{O}-\mathrm{STD}_{M}(1-\mathrm{Corr})}{\left(\beta \mathrm{RMS}_{U}\right)^{2}}$.

From Eq. (B12), the model performance criterion (MPC) for the error of bias, standard deviation and correlation can be derived. The bias MPC is derived from Eq. (B12) assuming Corr $=1$ and $\mathrm{STD}_{M}=\mathrm{STD}_{O}$, as follows:

$\operatorname{MPC}($ bias $)=\frac{\operatorname{Bias}^{2}}{\left(\beta \mathrm{RMS}_{U}\right)^{2}} \leq 1$.

The MQI as described by Eq. (B11) is used as main indicator in the Target diagram (Thunis et al., 2012a). In the normalised

10 Target diagram, it represents the distance between the origin and a given station point. The normalised bias (first term on the right hand side of Eq. (B12) is used for the y-axis while the centred root mean square error (CRMSE) (sum of the two last terms on the right hand side of Eq. (B12)) is used to define the X-axis. More details on the normalised Target diagram can be found in Thunis et al. (2012a).

Competing interests. The author declares that he has no conflict of interest.

Acknowledgements. The author thanks the city of Hamburg, Ministry of Environment and Energy (Behörde für Umwelt Energie Hamburg, BUE) for providing AQ monitoring data and the Agency for Immission Control and Plant Installations (Amt für Immissionsschutz und Betriebe, IB) for providing traffic emission data and industrial emission totals. The author kindly acknowledges Ingo Lange and the Meteorological Institute of Hamburg University for compiling and providing meteorological measurement data. Moreover, the author would like to thank Stefan Feigenspan and Stephan Nordmann of the German Federal Environmental Agency (Umweltbundesamt, UBA) for providing gridded emission totals for Hamburg. Britt Ann Høisker (NILU) is thanked for permission to distribute the CityChem-EPISODE model under the RPL license. Markus Quante (HZG) is acknowledged for valuable comments on the article. Comments from Volker Matthias (HZG) on an earlier version of the article are appreciated. The author is grateful to Martin Ramacher (HZG) for his work on the data sets for the study of Hamburg, including: (1) adoption of land cover and elevation data in TAPM; (2) performing TAPM runs to produce meteorological input data; (3) statistical performance analysis of TAPM meteorology; (4) preparation and initial setup of the DELTA Tool; (5) the ArcGIS assisted intersection of average individual building heights and land cover information in Hamburg to derive average building heights; (6) ArcGIS geographic maps in Figure 7(b, c, d); (7) contacting UBA, BUE and Hamburg University to gather and prepare input data; (8) tests of early CityChem-EPISODE builds; and (9) support with general information about Hamburg as a citizen. This work was in part funded by the BONUS SHEBA project under the joint Baltic research and development programme, co-financed by the European Union's 7th Framework Programme (2007-2013) and the national research funding institutions in the eight EU member states around the Baltic Sea. 
Geosci. Model Dev. Discuss., https://doi.org/10.5194/gmd-2018-8

Manuscript under review for journal Geosci. Model Dev.

Discussion started: 24 January 2018

(c) Author(s) 2018. CC BY 4.0 License.

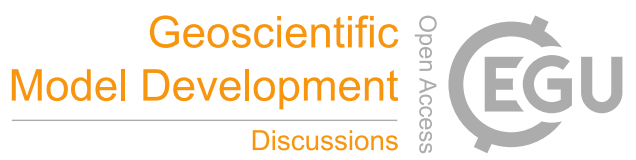

(c) (i)

\section{References}

Asman, W. A. H.: Parameterization of below-cloud scavenging of highly soluble gases under convective conditions, Atmos. Environ., 29(12), 1359-1368, doi:10.1016/1352-2310(95)00065-7, 1995.

Aulinger, A., Matthias, V., Zeretzke, M., Quante, M., and Backes, A.: The impact of shipping emissions on air pollution in the greater North

Sea region - Part 1: Current emissions and concentrations, Atmos. Chem. Phys., 16, 739-748, https://doi.org/10.5194/acp-16-739-2016, 2016.

Aulinger, A., Ramacher, M., Karl, M., and Matthias, V.: Primary and secondary particles from ship emissions in port cities, paper presented at the European Aerosol Conference, Zurich, Abstract SPS6N3fb, 2017.

Baklanov, A., Hänninen, O., Slørdal, L. H., Kukkonen, J., Bjergene, N., Fay, B., Finardi, S., Hoe, S. C., Jantunen, M., Karppinen, A., Rasmussen, A., Skouloudis, A., Sokhi, R. S., Sørensen, J. H., and Ødegaard, V.: Integrated systems for forecasting urban meteorology, air pollution and population exposure, Atmos. Chem. Phys., 7, 855-874, https://doi.org/10.5194/acp-7-855-2007, 2007.

Baklanov, A., Molina, L. T., Gauss, M. M.: Megacities, air quality and climate. Atmos. Environ. 126, 235-249, http://dx.doi.org/10.1016/j. atmosenv.2015.11.059, 2016.

Basu, S. and Porté-Agel, F.: Large-eddy simulation of stably stratified atmospheric boundary layer turbulence: A scale-dependent dynamic modelling approach, J. Atmos. Sci., 63, 2074-2091, 2006.

Batchvarova, E. and Gryning, S. E.: Applied model for the growth of the daytime mixed layer, Boundary-Layer Meteorology, 56, 261-274, 1991.

Beekmann, M., Prevôt, A.S.H., Drewnick, F., Sciare, J., Pandis, S. N., Denier van der Gon, H. A. C., Crippa, M., Freutel, F., Poulain, L., Ghersi, V., Rodriguez, E., Beirle, S., Zotter, P., von der Weiden-Reinmüller, S.-L., Bressi, M., Fountoukis, C., Petetin, H., Szidat, S., Schneider, J., Rosso, A., El Haddad, I., Megaritis, A., Zhang, Q. J., Michoud, V., Slowik, J. G., Moukhtar, S., Kolmonen, P., Stohl, A., Eckhardt, S., Borbon, A., Gros, V., Marchand, N., Jaffrezo, J. L., Schwarzenboeck, A., Colomb, A., Wiedensohler, A., Borrmann, S., Lawrence, M., Baklanov, A., and Baltensperger, U.: In situ, satellite measurement and model evidence on the dominant regional contribution to fine particulate matter levels in the Paris megacity. Atmos. Chem. Phys., 15, 9577-9591, https://doi.org/10.5194/acp-15-9577-2015, 2015

Behlen, A., Steiger, M. and Dannecker, W.: Deposition of sulfur dioxide to building stones: the influence of the ambient concentration on the deposition velocity, Environ. Geol., 56, 595-603, 2008.

Beljaars, A. C. M. and Holtslag, A. A. M.: Flux parameterization over land surfaces for atmospheric models. J. Appl. Meteor., 30, 327-341, 1991.

Berkowicz, R., Hertel, O., Larsen, S. E., Sørensen, N. N., and Nielsen, M.: Modelling traffic pollution in streets, Ministry of Environment and Energy, National Environmental Research Institute, Roskilde, Denmark, available at: http://www2.dmu.dk/1_viden/2_Miljoe-tilstand/3_ luft/4_spredningsmodeller/5_OSPM/5_description/ModellingTrafficPollution_report.pdf (Last Accessed: 22.11.2017), 1997.

Binkowski, F. and Shankar, U.: The Regional Particulate Matter Model .1. Model description and preliminary results, J. Geophys. Res., 100, 26191-26209, 1995.

BKG: Digitales Geländemodell Gitterweite 200 m, Bundesamt für Kartographie und Gedoäsie, available at: http://www.geodatenzentrum. de/docpdf/dgm200.pdf (Last Accessed: 22.11.2017), 2013.

Borge, R., Lumbreras, J., Perez, J., de la Paz, D., Vedrenne, M., de Andres, J. M., and Rodriguez, M. E.: Emission inventories and modelling requirements for the development of air quality plans. Application to Madrid (Spain), Sci. Total Environ., 466, 809-819, 2014. 
Geosci. Model Dev. Discuss., https://doi.org/10.5194/gmd-2018-8

Manuscript under review for journal Geosci. Model Dev.

Discussion started: 24 January 2018

(c) Author(s) 2018. CC BY 4.0 License.

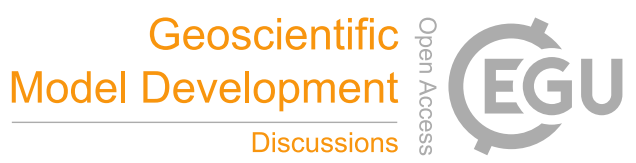

(c) (i)

Bott, A.: A positive definite advection scheme obtained by nonlinear renormalization of the advective fluxes. Mon. Wea. Rev. 117, 1006$1015,1989$.

Bott, A.: Monotone flux limitation in the area-preserving flux-form advection algorithm. Mon. Wea. Rev. 120, $2592-2602,1992$.

Bott, A.: The monotone area-preserving flux-form advection algorithm: reducing the timesplitting error in two-dimensional flow fields. Mon. Wea. Rev. 121. 2637-2641, 1993.

Briggs, G. A.: Plume Rise, US Atomic Energy Commission, Springfield, USA, 1-81, 1969.

Briggs, G. A.: Some recent analyses of plume rise observation, in: Proceedings of the Second International Clean Air Congress, edited by: Englund, H. M. and Berry, W. T., Academic Press, Washington, USA, 6-11 December 1970, 1029-1032, 1971.

Briggs, G. A.: Diffusion estimation for small emissions, Environmental research laboratories air resources atmospheric turbulence and diffusion laboratory 1973 annual report, USAEC Rep ATDL-106 Natl. Oceanic Atmos. Admin., Washington, DC, 1974.

Briggs, G. A.: Plume rise predictions, in: Lectures on Air Pollution and Environmental Impact Analysis, edited by: Haugen, D. A., Amer. Meteor. Soc., Boston, MA, pp. 59-111, 1975.

Bruemmer, B., Lange, I., and Konow, H.: Atmospheric boundary layer measurements at the 280 m high Hamburg weather mast 1995-2011: Mean annual and diurnal cycles, Meteorol. Z., 21, 319-335. doi:10.1127/0941-2948/2012/0338, 2012.

Businger, J. A. and Arya, S. P. S.: Height of the mixed layer in the stably stratified planetary boundary layer, in: Turbulent Diffusion in Environmental Pollution, edited by Frenkiel, F. N. and Munn, R. E, Adv. Geophys., 18A, Academic Press, New York, pp. 73-92, 1974.

Businger, J. A., Wyngaard, J. C., Izumi, Y. and Bradley, E. F.: Flux-profile relationships in the atmospheric surface layer, J. Atmos. Sci., 28, $181-189,1971$.

Bøhler, T.: MEPDIM. The NILU Meteorological Processor for Dispersion Modelling, Version 1.0, Model description, Norwegian Institute for Air Research, NILU TR 7/1996, Kjeller, Norway, 1996.

Byun, D. W. and Schere, K. L.: Review of the governing equations, computational algorithms and other components of the Models-3 Community Multiscale Air Quality (CMAQ) Modeling System. Appl. Mech. Rev. 59, 51-77, http://dx.doi.org/10.1115/1.2128636, 2006.

Byun, D. W., Young, J., Pleim, J., Odman, M. T., and Alapaty, K.: Chapter 7, Numerical Transport Algorithms for the Community Multiscale Air Quality (CMAQ) Chemical Transport Model in Generalized Coordinates, in: Science Algorithms of the EPA Models-3 Community Multiscale Air Quality (CMAQ) Modeling System. EPA/600/R-99/030, U.S. Environmental Protection Agency, Office of Research and Development, Washington, DC, 1999.

Carslaw, D. C. and Beevers, S. D.: Estimations of road vehicle primary $\mathrm{NO}_{2}$ exhaust emission fractions using monitoring data in London, Atmos. Environ., 39, 167-177, 2005.

Carslaw, D. C. and Rhys-Tyler, G.: New insights from comprehensive on-road measurements of $\mathrm{NO}_{\mathrm{X}}, \mathrm{NO}_{2}$ and $\mathrm{NH}_{3}$ from vehicle emission remote sensing in London, UK, Atmos. Environ., 81, 339-347, 2012.

CLC: Copernicus Land Monitoring Service, http://land.copernicus.eu/pan-european/corine-land-cover/clc-2012/ (Last Accessed: 22.11.2017), 2012.

Crutzen, P. J., and Lelieveld, J.: Human impacts on atmospheric chemistry, Annu. Rev. Earth Pl. Sc., 29, 17-45, 2001.

Denby, B. R., Sundvor, I., Schneider, P., Thanh, D. V.: Air quality maps of $\mathrm{NO}_{2}$ and $\mathrm{PM}_{10}$ for the region including Stavanger, Sandnes, Randaberg and Sola. Norwegian Institute for Air Research, NILU TR 01/2014, Kjeller, Norway, 2014.

Derbyshire, S. H.: Nieuwstadt's stable boundary layer revisited, Q. J. R. Meteorol. Soc., 116, 127-158, doi: 10.1002/qj.49711649106, 1990.

Donahue, N. M., Robinson, A. L., Pandis, S. N.: Atmospheric organic particulate matter: From smoke to secondary organic aerosol, Atmos. Environ., 43(1), 94-106 doi:10.1016/j.atmosenv.2008.09.055, 2009. 
Geosci. Model Dev. Discuss., https://doi.org/10.5194/gmd-2018-8

Manuscript under review for journal Geosci. Model Dev.

Discussion started: 24 January 2018

(c) Author(s) 2018. CC BY 4.0 License.

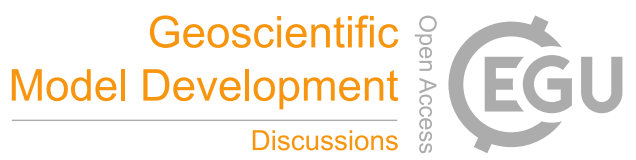

(c) (i)

EC: Directive 2008/50/EC of the European Parliament and of the Council of 21 May 2008 on ambient air quality and cleaner air for Europe,

European Commission, Official Journal of the European Union L152, 2008.

EEA: Air quality in Europe - 2015 Report, European Environment Agency, EEA Report. No. 5/2015, Copenhagen, 57 pp., 2015.

FAIRMODE: Modeling quality objectives in the framework of the FAIRMODE project: working document, Pernigotti, D., Gerboles, M. and Thunis, P., April 2014, available at: http://fairmode.jrc.ec.europa.eu/document/fairmode/WG1/Working\%20note_MQO.pdf (Last Accessed: 22.11.2017), 2014.

Geyer, B.: High-resolution atmospheric reconstruction for Europe 1948-2012: coastDat2, Earth Syst. Sci. Data, 6, 147-164, https://doi.org/ 10.5194/essd-6-147-2014, 2014.

Grice, S., Stedman, J., Kent, A., Hobson, M., Norris, J., Abbott, J., and Cooke, S.: Recent trends and projections of primary $\mathrm{NO}_{2}$ emissions in

Europe, Atmos. Environ., 43(13), 2154-2167, 2009.

Grote, R., Samson, R., Alonso, R., Amorim, J. H., Cariñanos, P., Churkina, G., Fares, S., Thiec, D. L., Niinemets, Ü., Mikkelsen, T. N., Paoletti, E., Tiwary, A., Calfapietra, C.: Functional traits of urban trees: air pollution mitigation potential, Front Ecol. Environ., 14(10), 543550, http://dx.doi.org/10.1002/fee.1426, 2016.

Guevara, M., Lopez-Aparicio, S., Cuvelier, C., Tarrason, L., Clappier,A ., and Thunis, P.: A benchmarking tool to screen and compare bottomup and top-down atmospheric emission inventories, Air Qual. Atmos. Health, 10, 627-642, https://doi.org/10.1007/s11869-016-0456-6, 2016.

Harrison, R. M., Dall'Osto, M., Beddows, D. C. S., Thorpe, A. J., Bloss, W. J., Allan, J. D., Coe, H., Dorsey, J. R., Gallagher, M., Martin, C., Whitehead, J., Williams, P. I., Jones, R. L., Langridge, J. M., Benton, A. K., Ball, S. M., Langford, B., Hewitt, C. N., Davison, B., Martin, D., Petersson, K. F., Henshaw, S. J., White, I. R., Shallcross, D. E., Barlow, J. F., Dunbar, T., Davies, F., Nemitz, E., Phillips, G. J., Helfter, C., Di Marco, C. F., and Smith, S.: Atmospheric chemistry and physics in the atmosphere of a developed megacity (London): an overview of the REPARTEE experiment and its conclusions, Atmos. Chem. Phys., 12, 3065-3114, https://doi.org/10.5194/acp-12-3065-2012, 2012.

Hertel, O. and Berkowicz, R.: Modelling Pollution from Traffic in a Street Canyon, Evaluation of Data and Model Development, National Environmental Research Institute, Roskilde, Denmark, 1989.

Hurley P.: TAPM v. 4, Part 1: Technical Description, CSIRO Marine and Atmospheric Research Paper No.25, ISBN: 978-1-921424-71-7, 2008.

Hurley, P., Physick, W., and Luhar, A.: TAPM - a practical approach to prognostic meteorological and air pollution modelling, Environ. Modell. Softw., 20, 737-752, doi:10.1016/j.envsoft.2004.04.006, 2005.

Karl, M.: City-scale Chemistry Transport Model CityChem-EPISODE (Release version 1.0), Zenodo, http://doi.org/10.5281/zenodo. 1116174, 2017.

Karl, M., Guenther, A., Köble, R., Leip, A., and Seufert, G.: A new European plant-specific emission inventory of biogenic volatile organic compounds for use in atmospheric transport models, Biogeosciences, 6, 1059-1087, https://doi.org/10.5194/bg-6-1059-2009, 2009.

Karl, M., Gross, A., Pirjola, L., and Leck, C.: A new flexible multicomponent model for the study of aerosol dynamics in the marine boundary layer, Tellus B, 63, 1001-1025, 2011

Karl, M., Castell, N., Simpson,D., Solberg, S., Starrfelt, J., Svendby,T., Walker, S.-E., and Wright, R. F.: Uncertainties in assessing the environmental impact of amine emissions from a $\mathrm{CO}_{2}$ capture plant, Atmos. Chem. Phys., 14, 8533-8557, https://doi.org/10.5194/ acp-14-8533-2014, 2014. 
Geosci. Model Dev. Discuss., https://doi.org/10.5194/gmd-2018-8

Manuscript under review for journal Geosci. Model Dev.

Discussion started: 24 January 2018

(c) Author(s) 2018. CC BY 4.0 License.

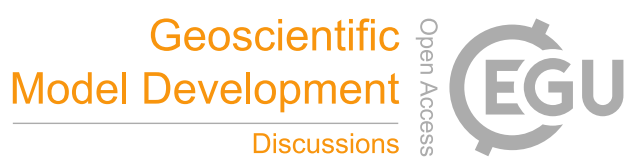

(c) (i)

Karl, M., Svendby, T., Walker, S.-E., Velken, A. S., Castell, N., and Solberg, S.: Modelling atmospheric oxidation of 2-aminoethanol (MEA) emitted from post-combustion capture using WRF-Chem, Sci. Total Environ., 527-528, 185-202, http://dx.doi.org/10.1016/j.scitotenv. 2015.04.108, 2015.

Karl, M., Kukkonen, J., Keuken, M. P., Lützenkirchen, S., Pirjola, L., and Hussein, T.: Modeling and measurements of urban aerosol processes on the neighborhood scale in Rotterdam, Oslo and Helsinki, Atmos. Chem. Phys., 16, 4817-4835, https://doi.org/10.5194/ acp-16-4817-2016, 2016.

Kikumoto, H. and Ooka, R.: A numerical study of air pollutant dispersion with bimolecular chemical reactions in an urban street canyon using large-eddy simulation, Atmos. Environ., 54, 456-464, https://doi.org/10.1016/j.atmosenv.2012.02.039, 2012.

Koepke, P., Garhammer, M., Hess, M., and Roeth, E.-P.: $\mathrm{NO}_{2}$ photolysis frequencies in street canyons, Atmos. Chem. Phys., 10, 7457-7466, https://doi.org/10.5194/acp-10-7457-2010, 2010.

Keuken, M. P., Roemer, M. G. M., Zandveld, P., Verbeek, R. P., and Velders, G. J. M.: Trends in primary $\mathrm{NO}_{2}$ and exhaust PM emissions from road traffic for the period 2000-2020 and implications for air quality and health in the Netherlands, Atmos. Environ., 54(0), 313-319, 2012.

Lamb, R. G. and Durran, D. R.: Eddy diffusivities derived from a numerical model of the convective boundary layer, Il Nuovo Cimento, 1c, $1-17,1978$.

Laupsa, H., and Slørdal, L. H.: Applying model calculations to estimate urban air quality with respect to the requirements of the EU directives on $\mathrm{NO}_{2}, \mathrm{PM}_{10}$ and $\mathrm{C}_{6} \mathrm{H}_{6}$. International Journal of Environmental Pollution, 20, 1-6, 2003.

LGV: 3-D city model LoD1-DE Hamburg, Freie und Hansestadt Hamburg, Landesbetrieb Geoinformation und Vermessung, available for download at: https://www.europeandataportal.eu/data/dataset/3d-stadtmodell-hamburg1/ (Last Accessed: 22.11.2017), 2014.

Marécal, V., Peuch, V.-H., Andersson, C., Andersson, S., Arteta, J., Beekmann, M., Benedictow, A., Bergström, R., Bessagnet, B., Cansado, A., Chéroux, F., Colette, A., Coman, A., Curier, R. L., Denier van der Gon, H. A.C., Drouin, A., Elbern, H., Emili, E., Engelen, R. J., Eskes, H.J., Foret,G., Friese, E., Gauss, M., Giannaros, C., Guth, J., Joly, M., Jaumouillé, E., Josse, B., Kadygrov, N., Kaiser, J. W., Krajsek, K., Kuenen, J., Kumar, U., Liora, N., Lopez, E., Malherbe, L., Martinez, I., Melas, D., Meleux, F., Menut, L., Moinat, P., Morales, T., Parmentier, J., Piacentini, A., Plu, M., Poupkou, A., Queguiner, S., Robertson, L., Rouïl, L., Schaap, M., Segers, A., Sofiev, M., Tarasson, L., Thomas, M., Timmermans, R., Valdebenito, Á., van Velthoven, P., van Versendaal, R., Vira, J., and Ung, A.: A regional air quality forecasting system over Europe: the MACC-II daily ensemble production, Geosci. Model Dev., 8, 2777-2813, https://doi.org/10.5194/gmd-8-2777-2015, 2015.

Mensink, C., Lefebre, F., De Ridder, K.: Developments and Applications in Urban Air Pollution Modelling, in: Faragó, I., Georgiev, K., Havasi, Á. (eds.) Advances in Air Pollution Modeling for Environmental Security. NATO Science Series (Series IV: Earth and Environmental Series), vol 54. Springer, Dordrecht, the Netherlands, 2005

Molina, M. J. and Molina, L. T.: Critical review: megacities and atmospheric pollution. J. Air Waste Manag. Assoc. 54, 644-680, 2004.

Nieuwstadt, F. T. M.: The steady-state height and resistance laws of the nocturnal boundary-layer: Theory compared with Cabauw observations, Boundary-Layer Meteorology, 20, 3-17, 1981.

Nieuwstadt, F. T. M. and Meeder J. P.: Large-Eddy Simulation of Air Pollution Dispersion: a Review, in: Métais O., Ferziger J. H. (eds.) New Tools in Turbulence Modelling. Centre de Physique des Houches, vol 5. Springer, Berlin, Heidelberg, pp. 265-280, 1997.

Oftedal, B., Walker, S. E., Gram, F., McInnes, H., Nafstad, P. P.: Modelling long-term averages of local ambient air pollution in Oslo, Norway: evaluation of nitrogen dioxide, $\mathrm{PM}_{10}$ and $\mathrm{PM}_{2.5}$. Int. J. Environ. Pollut., 36 (2), 110-126, doi:10.1504/IJEP.2009.021820, 2009. 
Geosci. Model Dev. Discuss., https://doi.org/10.5194/gmd-2018-8

Manuscript under review for journal Geosci. Model Dev.

Discussion started: 24 January 2018

(c) Author(s) 2018. CC BY 4.0 License.

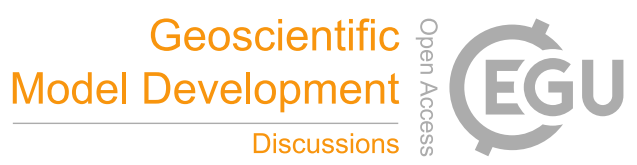

(c) (i)

Ottosen, T.-B., Kakosimos, K. E., Johansson, C., Hertel, O., Brandt, J., Skov, H., Berkowicz, R., Ellermann, T., Jensen, S. S., and Ketzel, M.: Analysis of the impact of inhomogeneous emissions in the Operational Street Pollution Model (OSPM), Geosci. Model Dev., 8, 32313245, https://doi.org/10.5194/gmd-8-3231-2015, 2015.

Owen, B., Edmunds, H. A., Carruthers, D. J., and Singles, R. J.: Prediction of total oxides of nitrogen and nitrogen dioxide concentrations in a large urban area using a new generation urban scale dispersion model with integral chemistry model, Atmos. Environ., 34, 397-406, 2000.

Pascal, M., Corso, M., Chanel, O., Declerq, C., Badaloni, C., Cesaroni, G., Henschel, S., Meister, K., Haluza, D., Martin-Olmedo, P., and Medina, S.: Assessing the public health impacts of urban air pollution in 25 European cities: Results of the Aphekom project, Sci. Total Environ., 449, 390-400, http://dx.doi.org/10.1016/j.scitotenv.2013.01.077, 2013.

Petersen, W. B.: User's Guide for Hiway-2: A Highway Air Pollution Model, US Environmental Protection Agency, EPA-600/8-80-018, Research Triangle Park, NC, USA, 1980.

Pernigotti, D., Thunis, P., Gerboles, M., Belis, C.: Model quality objectives based on measurement uncertainty: Part II: $\mathrm{PM}_{10}$ and NO 2 , Atmos. Environ., 79, 869-878, 2013.

Petetin, H., Beekmann, M., Colomb, A., Denier van der Gon,H. A. C., Dupont, J.-C., Honoré, C., Michoud, V., Morille, Y., Perrussel, O., Schwarzenboeck, A., Sciare, J., Wiedensohler, A., and Zhang, Q. J.: Evaluating BC and $\mathrm{NO}_{\mathrm{X}}$ emission inventories for the Paris region from MEGAPOLI aircraft measurements, Atmos. Chem. Phys., 15, 9799-9818, https://doi.org/10.5194/acp-15-9799-2015, 2015.

Platt, U., Alicke, B., Dubois, R., Geyer, A., Hofzumahaus, A., Holland, F., Martinez, M., Mihelcic, D., Klüppel, T., Lohrmann, B., Pätz, W., Perner, D., Rohrer, F., Schäfer, J., and Stutz, J.: Free radicals and fast photochemistry during BERLIOZ, J. Atm. Chem., 42, 359-394, 2002.

Pregger, T. and Friedrich, R.: Effective pollutant emission heights for atmospheric transport modelling based on real-world information, Environmental Pollution, 157, 552-560, doi:10.1016/j.envpol.2008.09.027, 2009.

PRTR, Pollutant Release and Transfer Register, PRTR-Gesamtdatenbestand (Stand: 20.09.2017), available for download at: http://www.thru. de/thrude/downloads/ (Last Accessed: 22.11.2017), 2017.

Ramacher, M. O. P., Karl, M., Aulinger, A., Bieser, J., Matthias, V., and Quante, M.: The impact from ships in ports on regional and urban scale air quality, Mensink, C., Kallos, G. (eds.), in: Air Pollution Modeling and its Application XXV, Springer Proceedings in Complexity, Springer International Publishing, 2018.

Rockel, B., Will, A., and Hense, A.: The Regional Climate Model COSMO-CLM (CCLM), Meteorol. Z., 347-348, 2008.

Rodriguez, E., Morris, C. S., Belz, J. E., Chapin, E. C., Martin, J. M., Daffer, W., and Hensley, S.: An assessment of the SRTM topographic products, Technical Report JPL D-31639, Jet Propulsion Laboratory, Pasadena, California, 143 pp, 2005.

Schneider, C., Pelzer, M. Toenges-Schuller, N., Nacken, M., and Niederau, A.: Gridding Emission Tool for ArcGIS (GRETA) (in German), ArcGIS basierte Lösung zur detaillierten, deutschlandweiten Verteilung (Gridding) nationaler Emissionsjahreswerte auf Basis des Inventars zur Emissionsberichterstattung. Umweltbundesamt, Texte 71/2016. ISSN 1862-4804, pp. 1-223, 2016.

Schneider, P., Castell, N., Vogt, M., Dauge, F. R., Lahoz, W. A., and Bartonova, A.: Mapping urban air quality in near real-time using observations from low-cost sensors and model information, Environment International, 106, 234-247, http://dx.doi.org/10.1016/j.envint.2017. $05.005,2017$.

Seibert, P., Beyrich, F., Gryning, S.-E., Joffre, S., Ramussen, A., and Tercier, P.: Review and intercomparison of operational methods for the determination of the mixing height, Atmos. Environ., 34, 1001-1027. 2000. 
Geosci. Model Dev. Discuss., https://doi.org/10.5194/gmd-2018-8

Manuscript under review for journal Geosci. Model Dev.

Discussion started: 24 January 2018

(c) Author(s) 2018. CC BY 4.0 License.

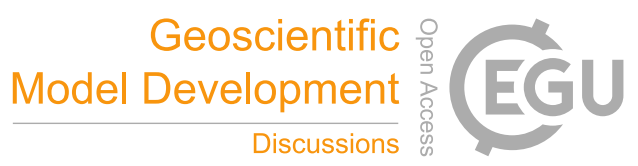

(c) (i)

Seinfeld, J. H. and Pandis, S. N.: Ch. 18.4, Equations Governing the Mean Concentration of Species in Turbulence, in: Atmospheric Chemistry and Physics, From Air Pollution to Climate Change, 2nd Edition, John Wiley \& Sons Inc., Hoboken, NJ, USA, 2006.

Shir, C. C.: A preliminary numerical study of atmospheric turbulent flows in the idealized planetary boundary layer, J. Atmos. Sci., 30, 1327-1339, 1973.

5 Sillman, S.: The relation between ozone, $\mathrm{NO}_{\mathrm{X}}$ and hydrocarbons in urban and polluted rural environments, Atm. Environ., 33(12), 1821$1845,1999$.

Simpson, D., Fagerli, H., Jonson, J. E., Tsyro, S., and Wind, P.: Transboundary Acidification, Eutrophication and Ground Level Ozone in Europe. Part 1: Unified EMEP Model Description, EMEP Status Report 1/2003, ISSN 0806-4520, Norwegian Meteorological Institute, Oslo, Norway, 2003.

Simpson, D., Benedictow, A., Berge, H., Bergström, R., Emberson, L. D., Fagerli, H., Flechard, C. R., Hayman, G. D., Gauss, M., Jonson, J. E., Jenkin, M. E., Nyíri, A., Richter, C., Semeena, V. S., Tsyro, S., Tuovinen, J.-P., Valdebenito, Á., and Wind, P.: The EMEP MSC-W chemical transport model - technical description, Atmos. Chem. Phys., 12, 7825-7865, https://doi.org/10.5194/acp-12-7825-2012, 2012.

Slørdal, L. H., Solberg, S., and Walker, S. E.: The Urban Air Dispersion Model EPISODE applied in AirQUIS2003, Technical description, Norwegian Institute for Air Research, NILU TR 12/2003, Kjeller, Norway, 2003.

Slørdal, L. H., McInnes, H., and Laupsa, H.: Dispersion and exposure calculations of $\mathrm{PM}_{10}, \mathrm{NO}_{2}$, and benzene for Oslo and Trondheim for the year 2005, Norwegian Institute for Air Research, NILU OR 90/2006, Kjeller, Norway, 2006.

Slørdal, L. H., McInnes, H., Krognes, T.: The Air Quality Information System AirQUIS, Info. Techn. Environ. Eng., 1, 21-33, 2008.

Smith, G. D.: Numerical solution of partial differential equations: finite difference methods, Clarendon Press, Oxford, U.K., 1985.

Sofiev, M., Kouznetsov, R., Prank, M., Soares, J., Vira, J., Tarvainen, V., and Sofieva, V.: A long-term re-analysis of atmospheric composition and air quality, Mensink, C., Kallos, G. (eds.), in: Air Pollution Modeling and its Application XXV, Springer Proceedings in Complexity, Springer International Publishing, 2018.

Stull, R. B.: An Introduction to Boundary Layer Meteorology, Kluwer Acad. Publ., Dordrecht, Boston, London, 666 pp., 1988.

Thunis, P. Pederzoli, A., Pernigotti, D.: Performance criteria to evaluate air quality modeling applications, Atmos. Environ., 79, 476-482, 2012a.

Thunis, P. Georgieva, E., and Pederzoli, A.: A tool to evaluate air quality model performances in regulatory applications, Environ. Model. Softw., 38, 220-230, https://doi.org/10.1016/j.envsoft.2012.06.005, 2012b.

Thunis, P., Pernigotti, D., Gerboles, M.: Model quality objectives based on measurement uncertainty: Part I: Ozone, Atmos. Environ., 79, 861-868, 2013.

Thunis, P., Miranda, A., Baldasano, J. M., Blond, N., Douros, J., Graff, A., Janssen, S., Juda-Rezler, K., Karvosenoja, N., Maffeis, G., Martilli, A., Rasoloharimahefa, M., Real, E., Viaene, P., Volta, M., and White, L.: Overview of current regional and local scale air quality modelling practices: Assessment and planning tools in the EU, Environ. Sci. Policy, 65, 13-21, https://doi.org/10.1016/j.envsci.2016.03.013, 2016.

Trebs, I., Bohn, B., Ammann,C., Rummel, U., Blumthaler, M., Küigstedt,R., Meixner,F.X., Fan, S., and Andreae, M. O.: Relationship between the $\mathrm{NO}_{2}$ photolysis frequency and the solar global irradiance, Atmos. Meas. Tech., 2, 725-739, https://doi.org/10.5194/ amt-2-725-2009, 2009.

UBA: Handbook of Emission Factors for Road Transport (in German), HBEFA version 3.1, Umweltbundesamt Berlin, available at: http: //www.hbefa.net/d/ (Last Accessed: 22.11.2017), 2010. 
Geosci. Model Dev. Discuss., https://doi.org/10.5194/gmd-2018-8

Manuscript under review for journal Geosci. Model Dev.

Discussion started: 24 January 2018

(c) Author(s) 2018. CC BY 4.0 License.

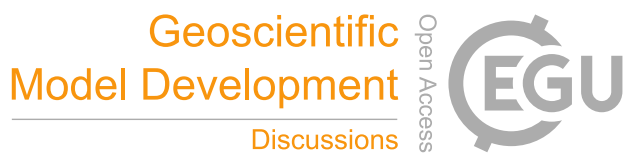

(c) (i)

U.S.EPA: User's Guide for the AMS/EPA Regulatory Model - AERMOD. EPA-454/B-03-001. U.S. Environmental Protection Agency, Research Triangle Park, NC, 2004.

Valach, A. C., Langford, B., Nemitz, E., MacKenzie, A. R., and Hewitt, C. N.: Seasonal and diurnal trends in concentrations and fluxes of volatile organic compounds in central London, Atmos. Chem. Phys., 15, 7777-7796, https://doi.org/10.5194/acp-15-7777-2015, 2015.

5 Valverde, V., Pay, M. T., and Baldasano, J. M.: Ozone attributed to Madrid and Barcelona on-road transport emissions: Characterization of plume dynamics over the Iberian Peninsula, Sci. Tot. Environ., 543, 670-682, http://dx.doi.org/10.1016/j.scitotenv.2015.11.070, 2016.

van Ulden, A. P. and Holtslag, A. A. M.: Estimation of Atmospheric Boundary Layer Parameters for Diffusion Applications, J. Appl. Meteor., 24, 1196-1207, 1985.

Verwer, J. and Simpson, D.: Explicit methods for stiff ODEs from atmospheric chemistry, Applied Numerical Mathematics, 18, 413-430, 10 1995.

Vickers, D. and Mahrt, L.: Evaluating formulations of stable boundary layer height, J. Appl. Meteorology, 43, 1736-1749, https://doi.org/10. 1175/JAM2160.1, 2004.

Walker, S. E. and Grønskei, K. E.: Spredningsberegninger for on-line overvakning i Grenland. Programbeskrivelse og brukerveiledning (In Norwegian), Norwegian Institute for Air Research, NILU OR 55/92, Kjeller, Norway, 1992.

15 Wang,Z. B., Hu, M., Mogensen, D., Yue, D. L., Zheng, J., Zhang, R. Y., Liu, Y., Yuan, B., Li, X., Shao, M., Zhou, L., Wu, Z. J., Wiedensohler, A., and Boy, M.: The simulations of sulfuric acid concentration and new particle formation in an urban atmosphere in China, Atmos. Chem. Phys., 13, 11157-11167, https://doi.org/10.5194/acp-13-11157-2013, 2013.

Wesely, M. L.: Parameterization of surface resistances to gaseous dry deposition in regional-scale numerical models. Atmos. Environ., 23, 1293-1304, 1989.

Zhao, Y., Nguyen, N. T., Presto, A. A., Hennigan, C. J., May, A. A., and Robinson, A. L.: Intermediate volatility organic compound emissions from on-road diesel vehicles: chemical composition, emission factors, and estimated secondary organic aerosol production, Environ. Sci. Technol., 49(19), 11516-11526, doi:10.1021/acs.est.5b02841, 2015.

Zhang, R., Khalizov, A., Wang, L., Hu, M., and Xu, W.: Nucleation and growth of nanoparticles in the atmosphere, Chem. Rev., 112, 19572011, doi:10.1021/cr2001756, 2012. 
Geosci. Model Dev. Discuss., https://doi.org/10.5194/gmd-2018-8 Manuscript under review for journal Geosci. Model Dev.

Discussion started: 24 January 2018

(c) Author(s) 2018. CC BY 4.0 License.
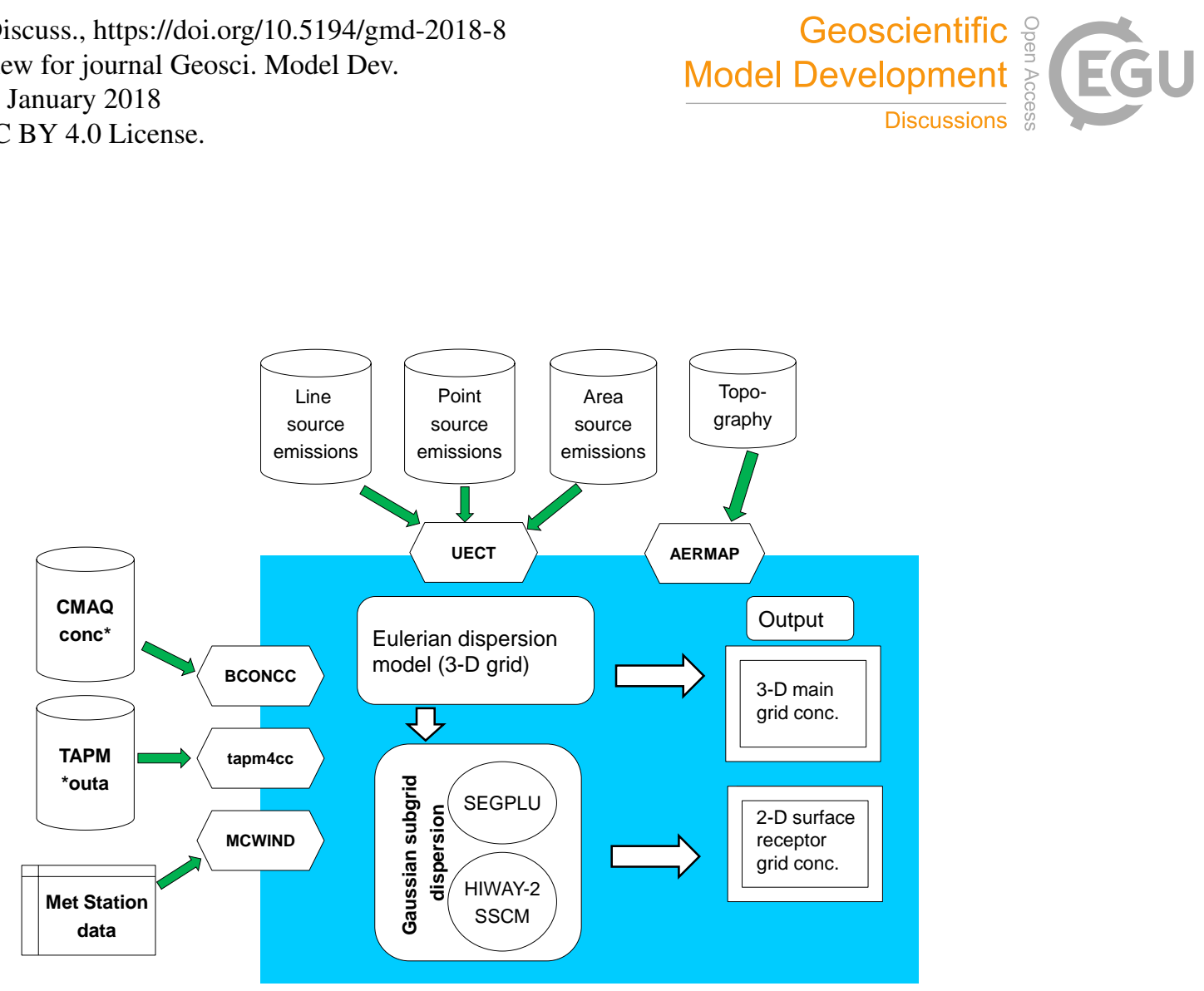

Figure 1. Overview of CityChem-EPISODE model components: utilities, interfaces and output grids.

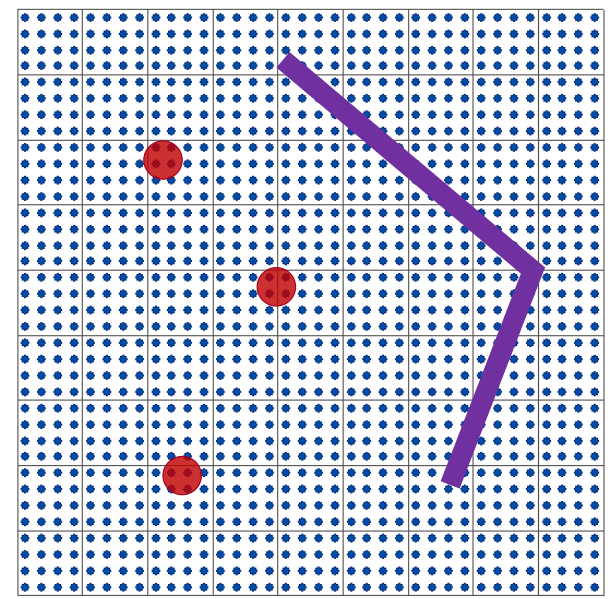

Figure 2. Illustration of the main grid and the regular receptor grid in CityChem. The black lines represent the gridlines of the main grid while the blue dots represent the regular receptor grid. The objects in red are point sources and objects in purple are line sources, for which sub-grid dispersion is applied. 
Geosci. Model Dev. Discuss., https://doi.org/10.5194/gmd-2018-8

Manuscript under review for journal Geosci. Model Dev.

Discussion started: 24 January 2018

(c) Author(s) 2018. CC BY 4.0 License.

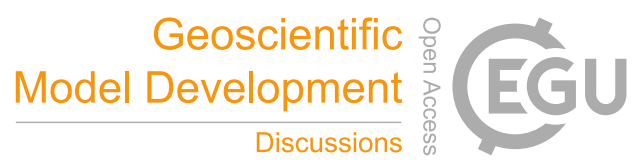

(c) (i)

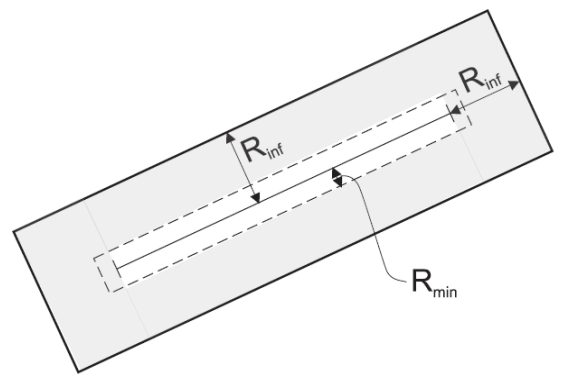

Figure 3. Illustration of the resulting rectangular influence zone around a line source (grey-shaded area); $R_{\text {inf }}$ is the influence distance. Receptor points that are closer than a minimum distance of $\mathrm{R}_{\min }$ from the line source, the receptor point is moved away to a distance $\mathrm{R}_{\min }$ from the line source to avoid that a receptor point is located in the cut section.

(a)

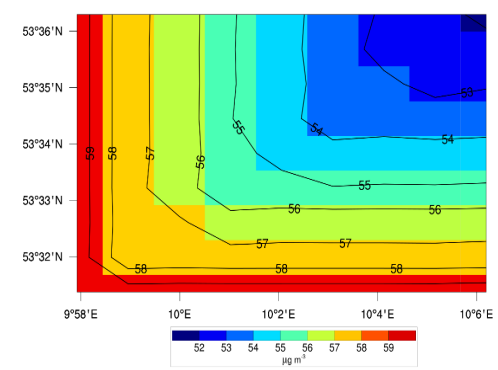

(d)

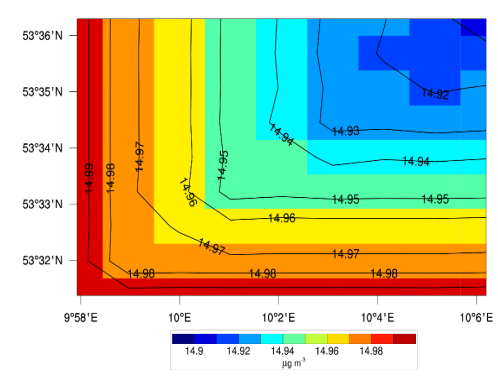

(b)

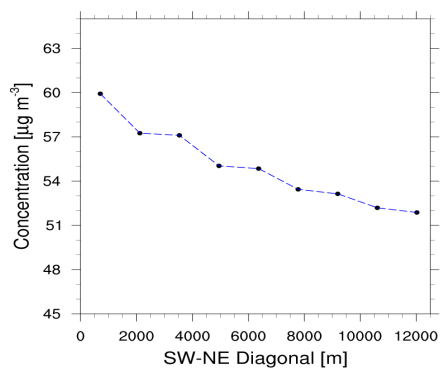

(e)

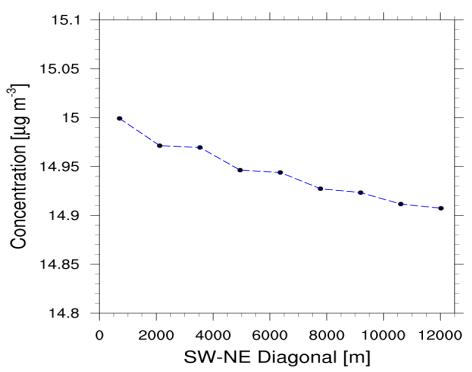

(c)

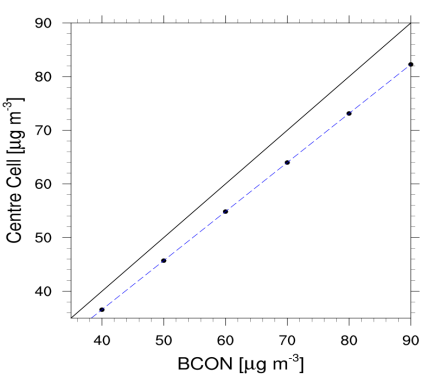

(f)

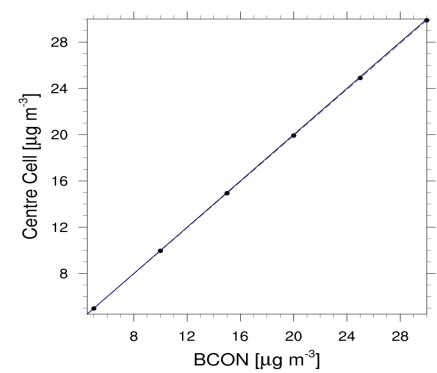

Figure 4. Boundary condition test for the entrainment of non-reactive tracers into the model domain of "testcity", (a) $\mathrm{O}_{3}$ surface field (BCON 60 ?g m-3), (b) $\mathrm{O}_{3}$ gradient along the SW-NE diagonal (BCON $60 \mu \mathrm{g} \mathrm{m}^{-3}$ ), (c) $\mathrm{O}_{3}$ of the centre cell as function of BCON value, d) $\mathrm{PM}_{2.5}$ surface field (BCON $15 \mu \mathrm{g} \mathrm{m}^{-3}$ ), (e) $\mathrm{PM}_{2.5}$ gradient along the SW-NE diagonal (BCON $15 \mu \mathrm{g} \mathrm{m}^{-3}$ ) and (f) $\mathrm{PM}_{2.5}$ of the centre cell as function of BCON value. Spatial distribution of $\mathrm{O}_{3}$ and $\mathrm{PM}_{2.5}$ concentrations in the surface layer was taken as average of a 5-day period. Black line in figure part (c) and (f) represent the 1:1 line. 
Geosci. Model Dev. Discuss., https://doi.org/10.5194/gmd-2018-8 Manuscript under review for journal Geosci. Model Dev.

Discussion started: 24 January 2018

(c) Author(s) 2018. CC BY 4.0 License.

(c) (i) (a)

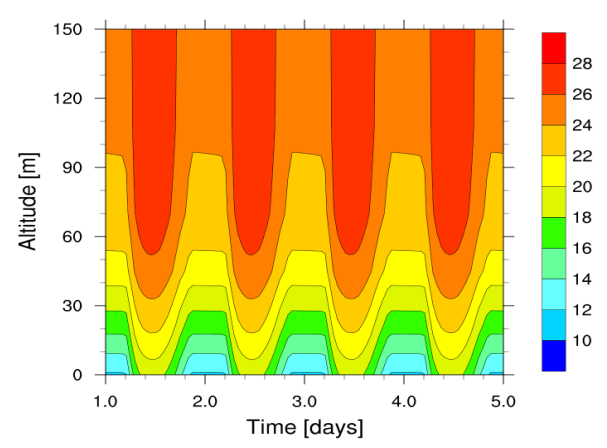

(c)

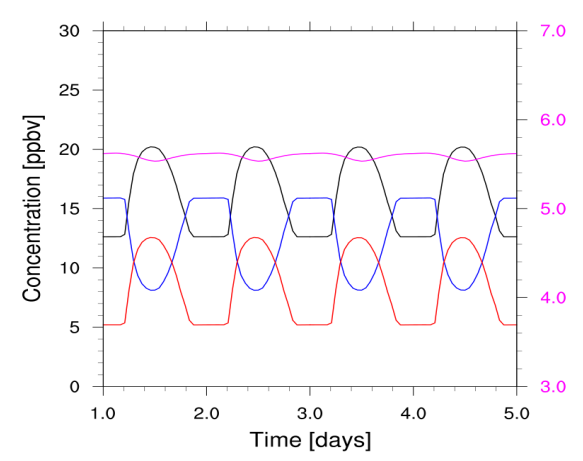

(b)

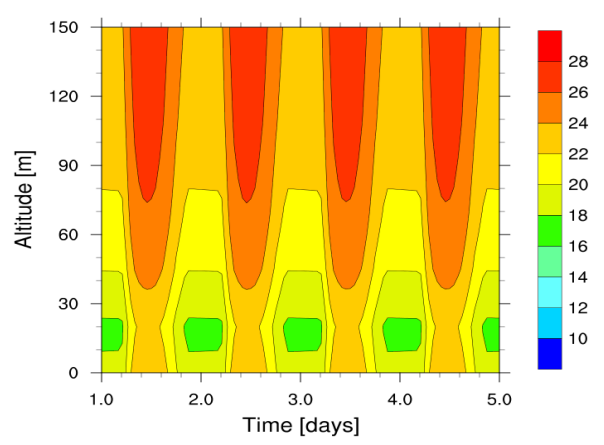

(d)

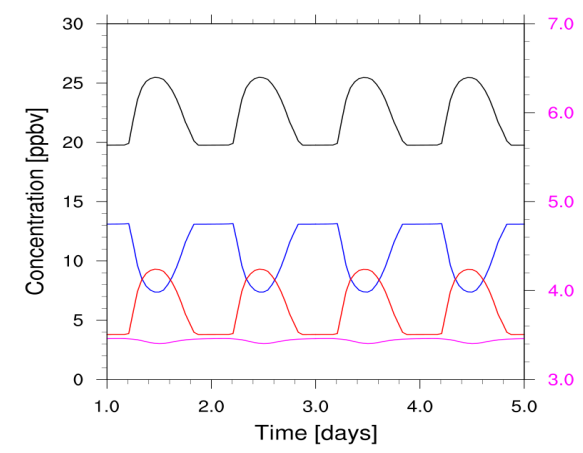

Figure 5. Vertical eddy diffusivity using two methods: vertical profile of $\mathrm{O}_{3}$ mixing ratios (ppbv) as a 4-day time sequence (starting at midnight of the second simulation day) in the centre cell for (a) standard $K^{(z)}$-method, and (b) new urban $K^{(z)}$-method, and time series of ground air (lowermost model layer) concentrations (ppbv) of $\mathrm{O}_{3}$ (black), $\mathrm{NO}$ (red), $\mathrm{NO}_{2}$ (blue) and HC-tot (magenta, second y-axis) in the centre cell for (c) standard $K^{(z)}$-method and (d) new urban $K^{(z)}$-method. 
Geosci. Model Dev. Discuss., https://doi.org/10.5194/gmd-2018-8

Manuscript under review for journal Geosci. Model Dev.

Discussion started: 24 January 2018

(c) Author(s) 2018. CC BY 4.0 License.

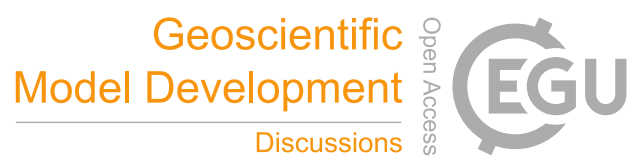

(c) (i)

(a)

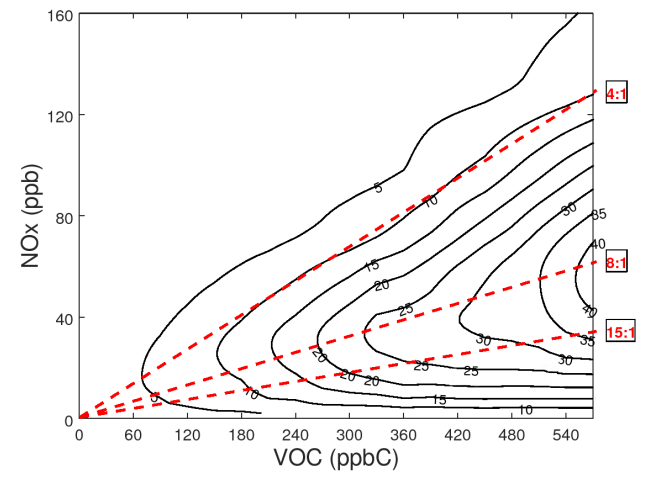

(c)

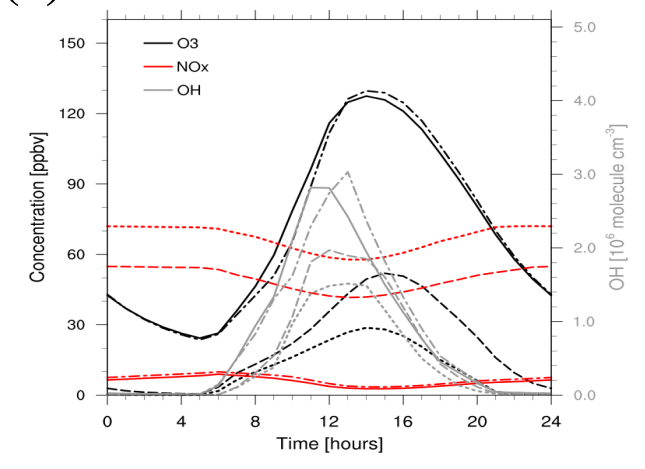

(b)

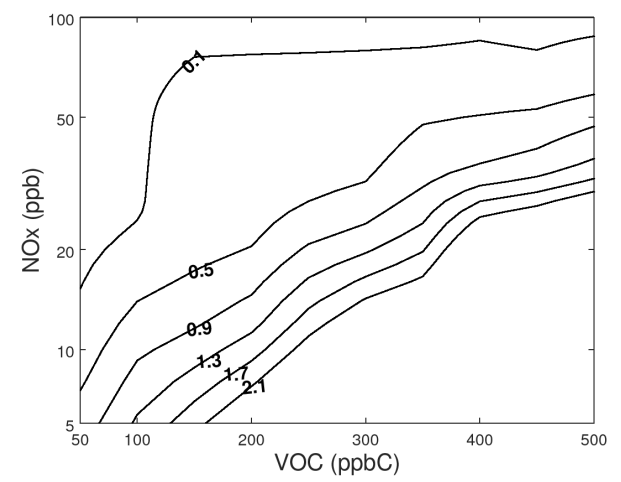

(d)

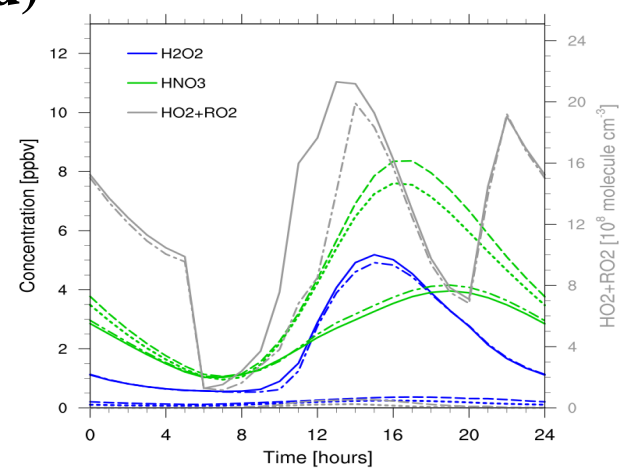

Figure 6. Test of relationship between relation between ozone, $\mathrm{NO}_{\mathrm{X}}$ and NMVOC in the photochemical reaction mechanism "CC45": (a) ozone isopleth diagram, (b) isopleth diagram showing the ratio of the production rate of peroxides to the production rate of nitric acid, (c) concentration time series of $\mathrm{O}_{3}$ (black), $\mathrm{NO}_{\mathrm{X}}$ (red), and $\mathrm{OH}$ (grey; second y-axis) and (d) concentration time series of $\mathrm{H}_{2} \mathrm{O}_{2}\left(\right.$ blue), $\mathrm{HNO}_{3}$ (green), and $\mathrm{HO}_{2}+\mathrm{RO}_{2}$ concentration (grey, second y-axis). Concentrations are shown for the fifth day from a test run with NMVOC emission of $6.952 \mathrm{~g} \mathrm{~s}^{-1}$ and varying $\mathrm{NO}_{\mathrm{X}}$ emissions: $0.01 \mathrm{~g} \mathrm{~s}^{-1}$ (solid lines), $0.021 \mathrm{~g} \mathrm{~s}^{-1}$ (dash-dotted lines), $0.379 \mathrm{~g} \mathrm{~s}^{-1}$ (dashed lines), and $0.546 \mathrm{~g} \mathrm{~s}^{-1}$ (dotted lines). Lines of constant $\mathrm{VOC} / \mathrm{NO}_{\mathrm{X}}$ ratio $(4: 1,8: 1$ and 15:1) are annotated with red dashed lines in part (a). Note the logarithmic scale of the y-axis in part (b). All concentrations were taken from the grid centre cell at the lowermost layer. 
Geosci. Model Dev. Discuss., https://doi.org/10.5194/gmd-2018-8 Manuscript under review for journal Geosci. Model Dev.

Discussion started: 24 January 2018

(c) Author(s) 2018. CC BY 4.0 License.

(a)

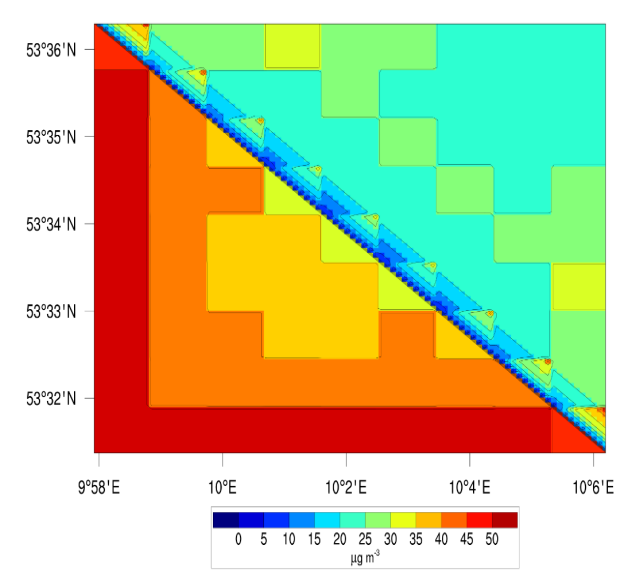

(b)

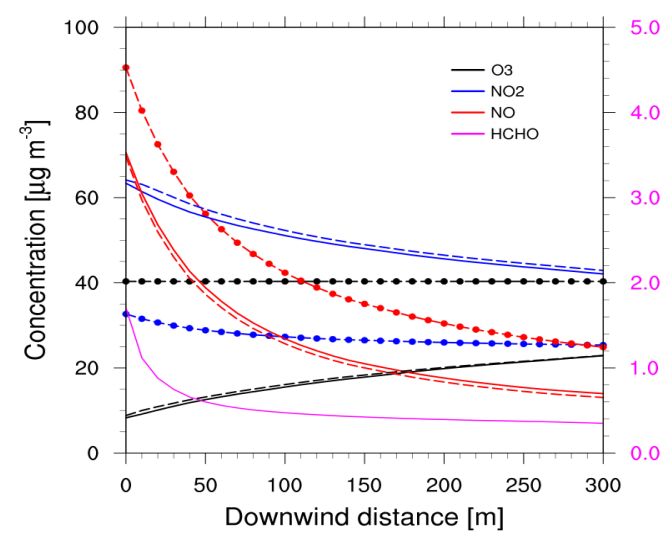

Figure 7. Photochemistry downwind of a line source in the SE-NW diagonal of the model domain "testcity": (a) $\mathrm{O}_{3}$ surface concentration $\left(\mu \mathrm{g} \mathrm{m}^{-3}\right)$ taken from the receptor grid $\left(100 \times 100 \mathrm{~m}^{2}\right)$ output when using PSSA in the sub-grid model and (b) concentration of $\mathrm{O}_{3}$ (black), NO (red), $\mathrm{NO}_{2}$ (blue) and $\mathrm{HCHO}$ (magenta, second y-axis) downwind of the line source recorded by receptor points every $10 \mathrm{~m}$ up to a distance of $300 \mathrm{~m}$ in the centre cell. Concentrations are shown for the test with no chemistry (line with filled circles), with PSSA (solid line) and with "CC10" (dashed line and magenta line). 
Geosci. Model Dev. Discuss., https://doi.org/10.5194/gmd-2018-8

Manuscript under review for journal Geosci. Model Dev.

Discussion started: 24 January 2018

(c) Author(s) 2018. CC BY 4.0 License.

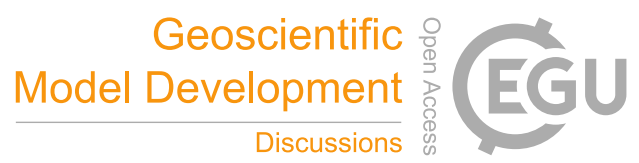

(c) (i)

(a)

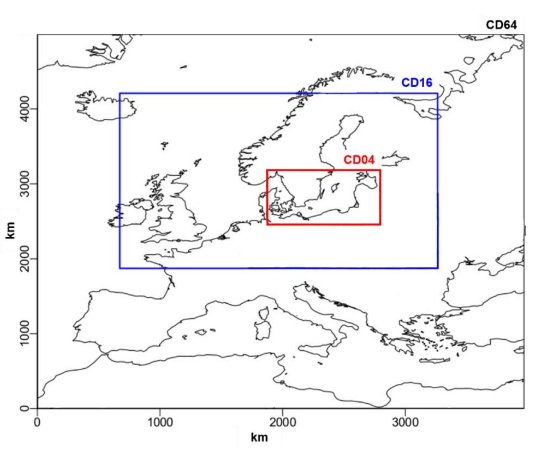

(c)

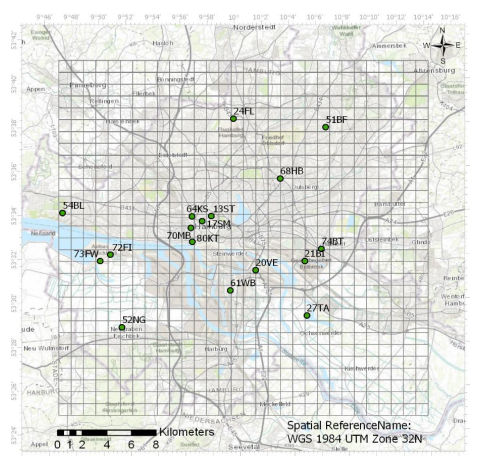

(b)

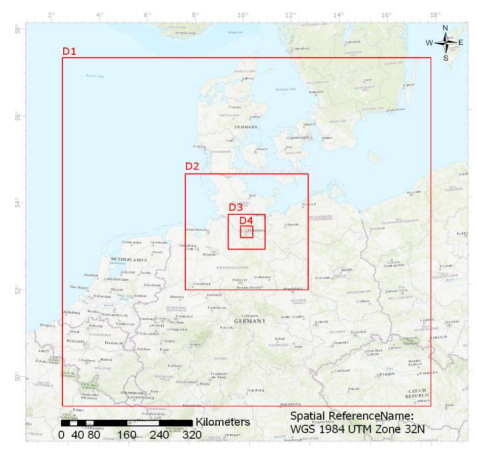

(d)

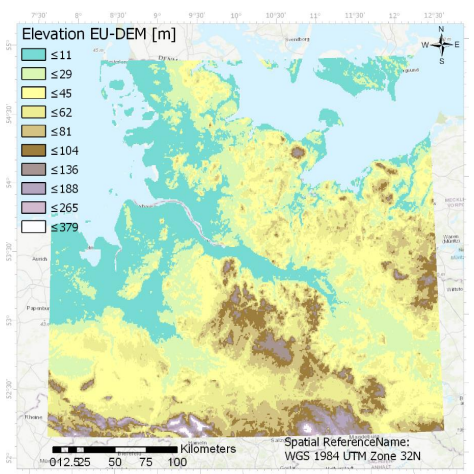

Figure 8. Model domains: (a) for the nested CTM simulations with CMAQ showing the 64-km (CD64), 16-km (CD16) and 4-km (CD04) resolution nests (SW corner of CD64 at [0; 0] corresponds to the lat-lon coordinate [28.402198 N; 9.685191 W]); (b) TAPM domains for the meteorology runs (D1-D4), (c) study domain of Hamburg $\left(30 \times 30 \mathrm{~km}^{2}\right)$ for simulation with CityChem, corresponds to the innermost nest (D4) of the nested model chain of both CMAQ and TAPM simulations. Green dots indicate positions of stations of the air quality monitoring network, and (d) terrain elevation (m a.s.1.) from the Digital Elevation Model over Europe (EU-DEM; https://www.eea.europa. eu/data-and-maps/data/eu-dem) for the extent of D2. 
Geosci. Model Dev. Discuss., https://doi.org/10.5194/gmd-2018-8 Manuscript under review for journal Geosci. Model Dev.

Discussion started: 24 January 2018

(c) Author(s) 2018. CC BY 4.0 License.

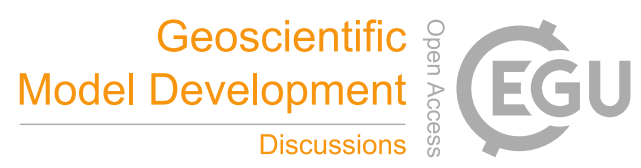

(c) (i)

(a)

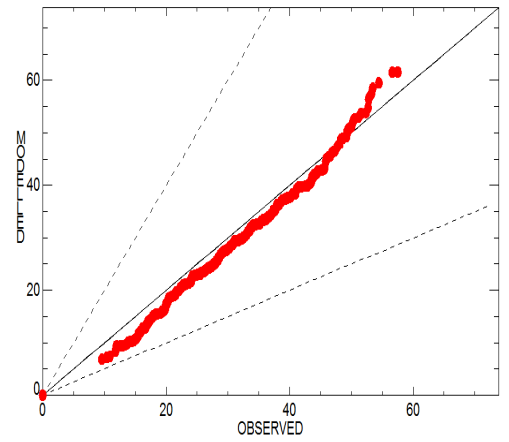

(c)

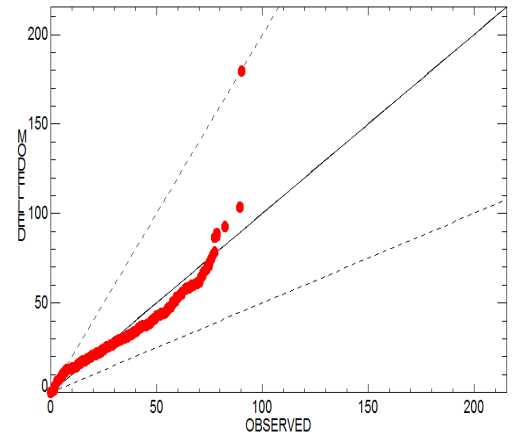

(e)

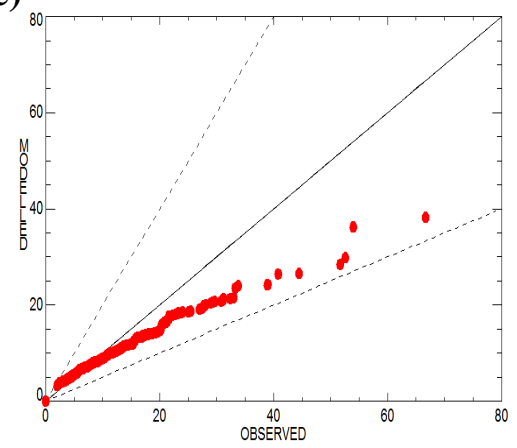

(b)

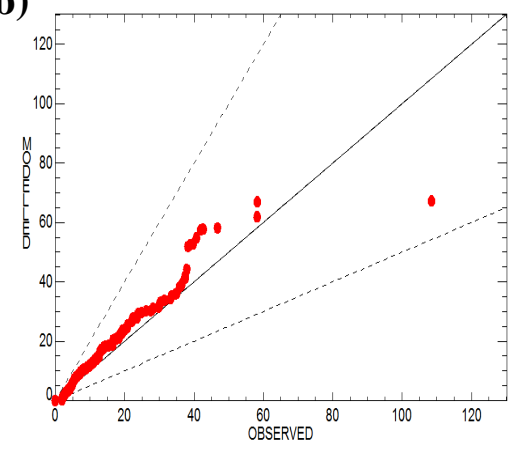

(d)

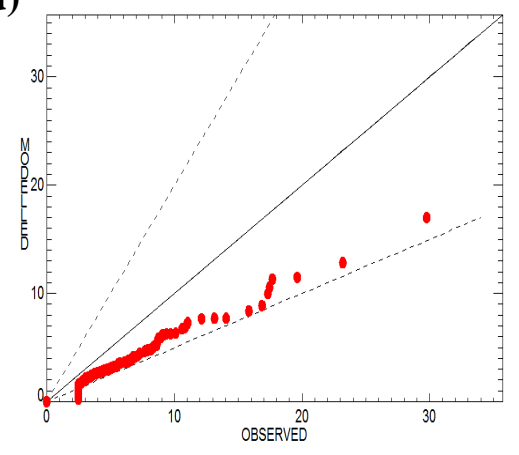

(f)

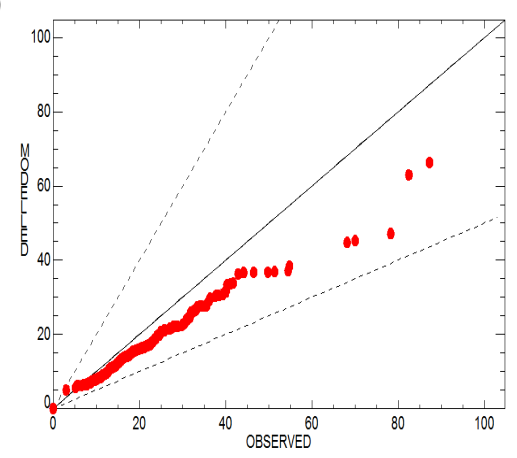

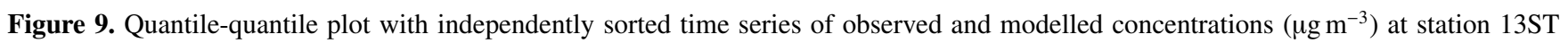
(Sternschanze): (a) $\mathrm{NO}_{2}$ (daily mean), (b) $\mathrm{NO}$ (daily mean), (c) $\mathrm{O}_{3}$ (daily maximum of 8-h running mean), (d) $\mathrm{SO}_{2}$ (daily mean), (e) $\mathrm{PM}_{2.5}$ (daily mean), and (f) $\mathrm{PM}_{10}$ (daily mean). Lowest value of $\mathrm{SO}_{2}$ observation data is $2.5 \mu \mathrm{g} \mathrm{m}^{-3}$ (detection limit of the method). Solid line indicates the 1:1 relationship and the dashed lines indicates the 2:1 or 1:2 relationships. 
Geosci. Model Dev. Discuss., https://doi.org/10.5194/gmd-2018-8 Manuscript under review for journal Geosci. Model Dev.

Discussion started: 24 January 2018

(c) Author(s) 2018. CC BY 4.0 License.

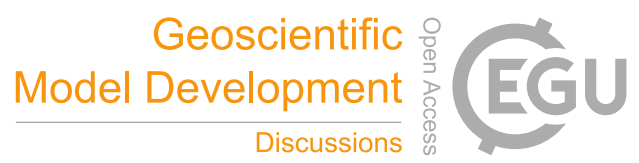

(c) (i)

(a)

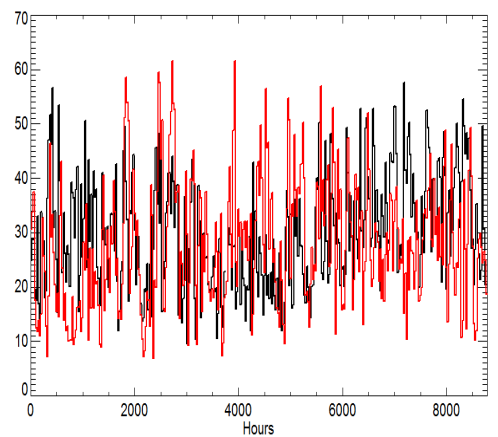

(c)

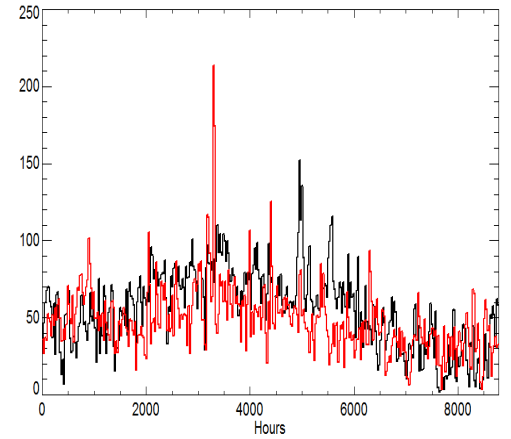

(e)

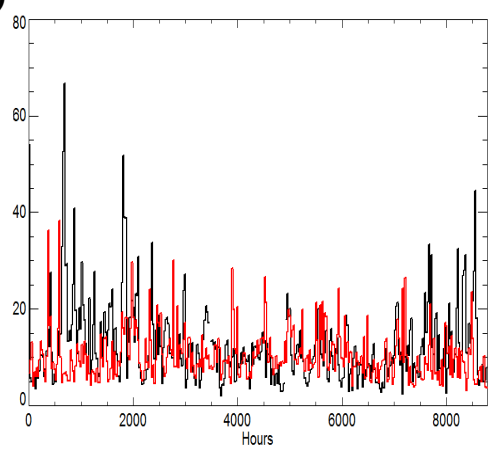

(b)

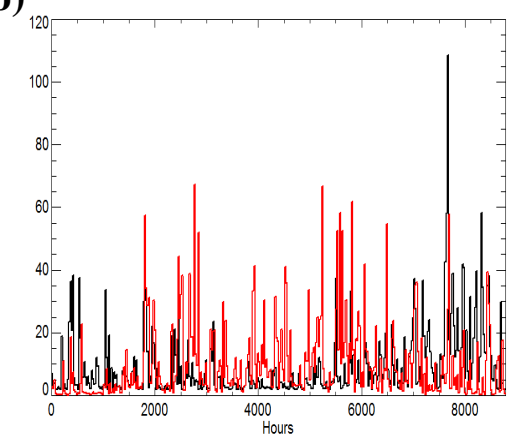

(d)

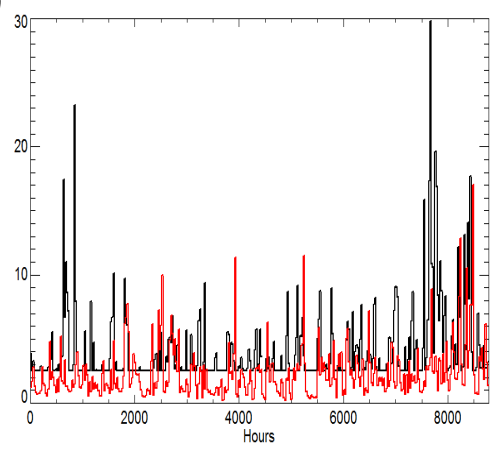

(f)

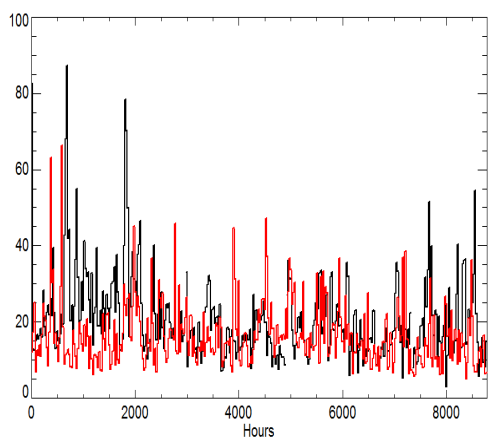

Figure 10. Time series comparing modelled and observed concentrations $\left(\mu \mathrm{g} \mathrm{m}^{-3}\right)$ at Sternschanze (station $13 \mathrm{ST}$ ): (a) $\mathrm{NO}_{2}$ (daily mean), (b) $\mathrm{NO}$ (daily mean), (c) $\mathrm{O}_{3}$ (maximum of daily 8-h running mean), (d) $\mathrm{SO}_{2}$ (daily mean), (e) $\mathrm{PM}_{2.5}$ (daily mean), and (f) $\mathrm{PM}_{10}$ (daily mean). Observed values black lines, modelled values indicated as red lines. Lowest value of $\mathrm{SO}_{2}$ observation data is $2.5 \mu \mathrm{g} \mathrm{m}{ }^{-3}$ (detection limit of the method). 
Geosci. Model Dev. Discuss., https://doi.org/10.5194/gmd-2018-8

Manuscript under review for journal Geosci. Model Dev.

Discussion started: 24 January 2018

(c) Author(s) 2018. CC BY 4.0 License.

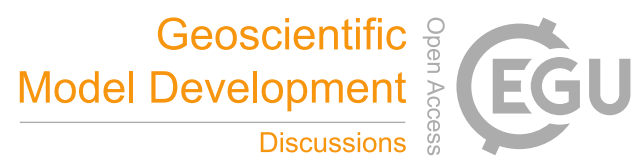

(c) (i)

(a)

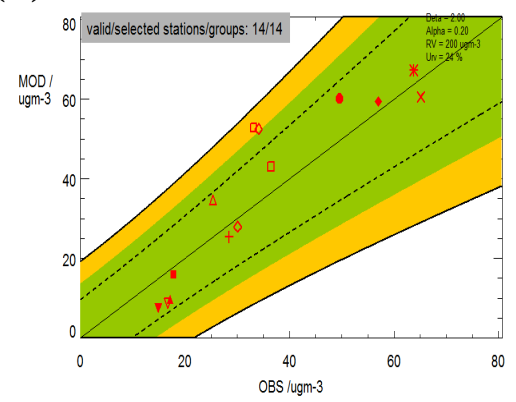

(d)

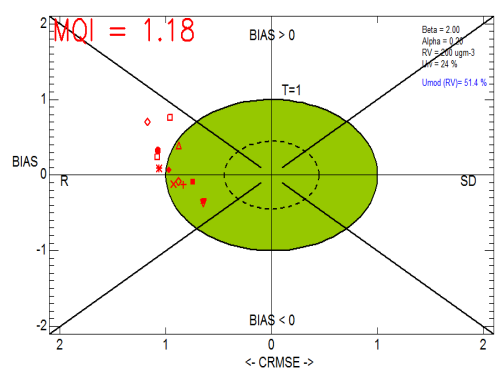

(b)

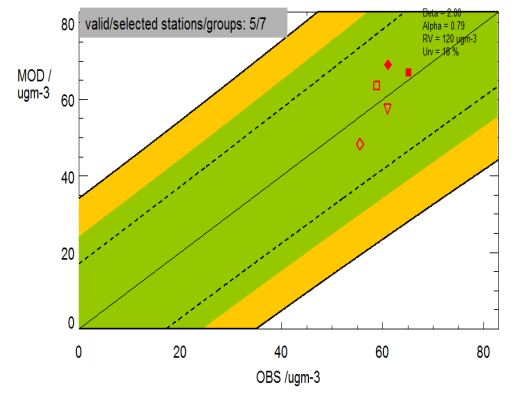

(e)

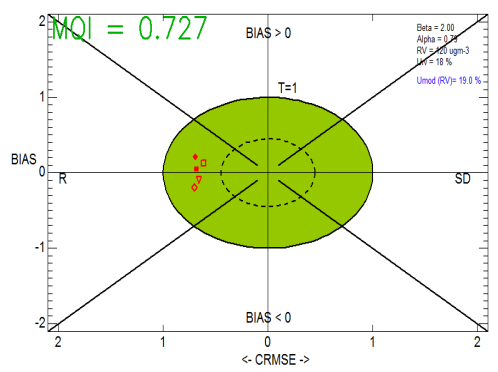

(c)

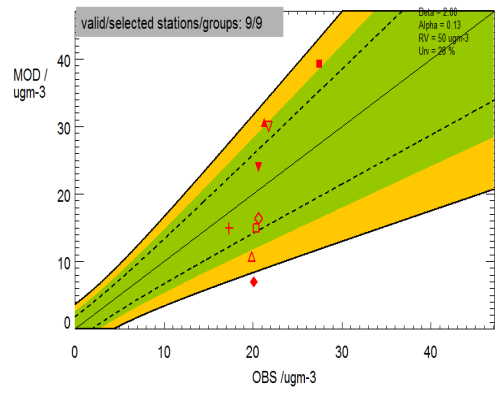

(f)

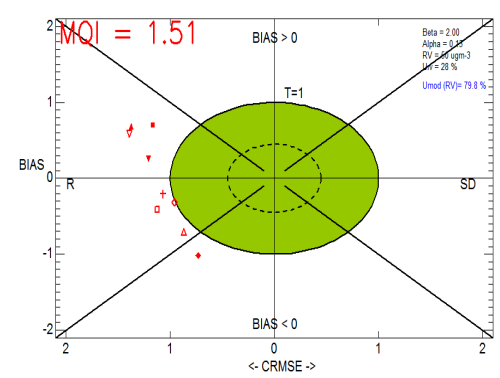

Figure 11. Model performance evaluation for monitoring stations of the Hamburg AQ network: (a) scatter diagram for $\mathrm{NO}_{2}$ hourly values, (b) scatter diagram for $\mathrm{O}_{3}$ daily max. of 8-h running mean, (c) scatter diagram for $\mathrm{PM}_{10}$ daily values (d) target plot $\mathrm{NO}_{2}$ hourly values, (e) target plot $\mathrm{O}_{3}$ daily max. of 8-h running mean, and (f) target plot $\mathrm{PM}_{10}$ daily values. Only stations with observation data completeness of $75 \%$ during 2012 for the respective air pollutant are included in the evaluation. In the scatter diagrams, the uncertainty parameters ( $\beta$, $\alpha$, $\mathrm{RV}, u_{r}^{R V}$ ) used to produce the diagram calculated are listed on the top right-hand side; dashed and solid lines indicate $\mathrm{NMB} / 2 \mathrm{RMS}{ }_{U}$ ratios of 0.5 and 1. In the Target diagrams also the MQI value for the station most distant from the origin and the model uncertainty, Umod(RV), are indicated. 
Geosci. Model Dev. Discuss., https://doi.org/10.5194/gmd-2018-8 Manuscript under review for journal Geosci. Model Dev.

Discussion started: 24 January 2018

(c) Author(s) 2018. CC BY 4.0 License. (a)

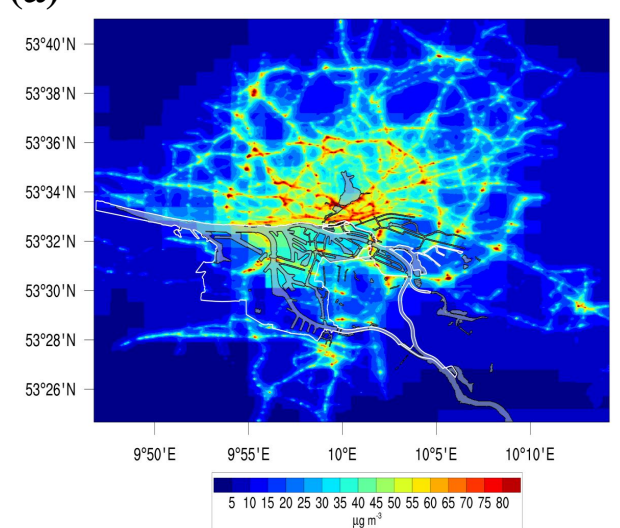

(c)

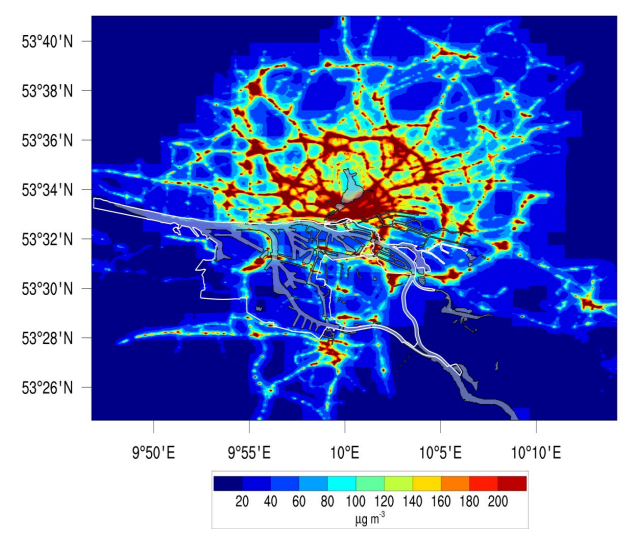

(e)

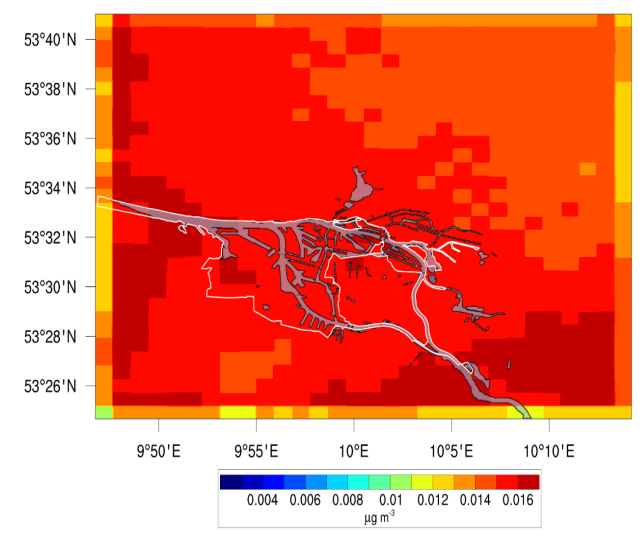

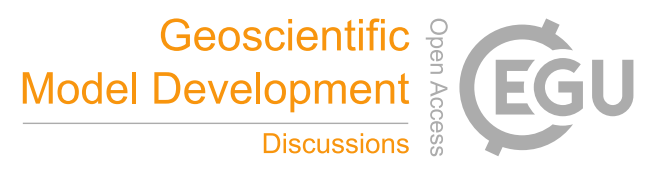

(b)

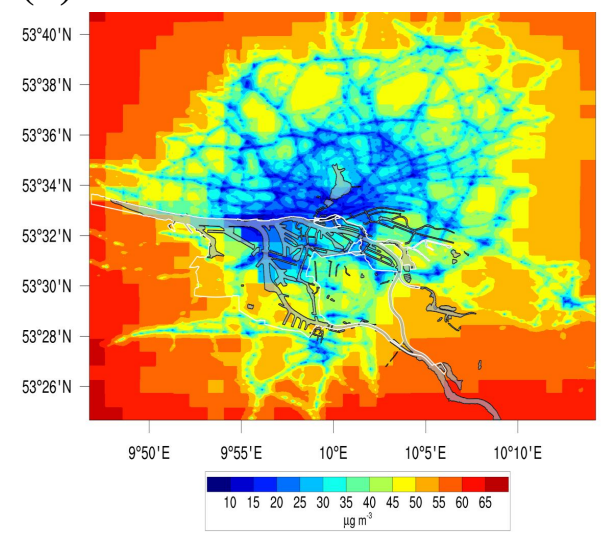

(d)

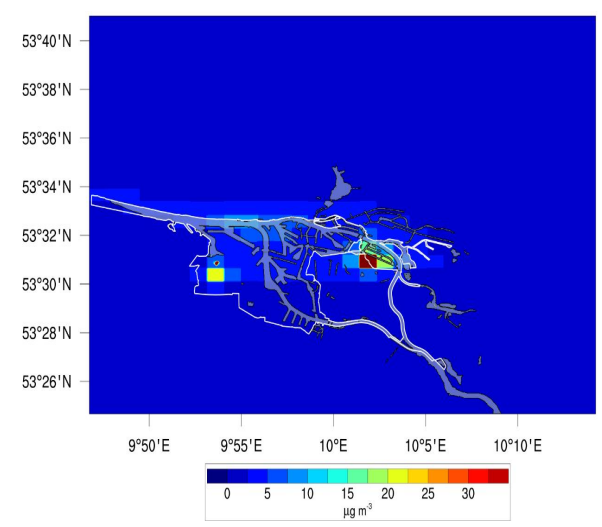

(f)

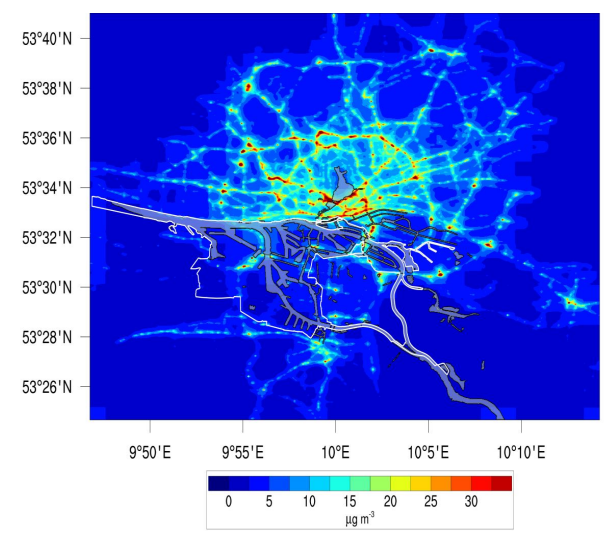

Figure 12. Spatial maps of the annual concentration average $\left(\mu \mathrm{g} \mathrm{m}^{-3}\right)$ for Hamburg from CityChem model simulation output for the receptor grid $\left(100 \times 100 \mathrm{~m}^{2}\right.$ ): (a) $\mathrm{NO}_{2}$, (b) $\mathrm{O}_{3}$, (c) total NMVOC, (d) $\mathrm{SO}_{2}$, (e) $\mathrm{H}_{2} \mathrm{SO}_{4}$, and (f) $\mathrm{PM}_{2.5}$. White outline illustrates harbour areas and black outline illustrates water bodies. 
Geosci. Model Dev. Discuss., https://doi.org/10.5194/gmd-2018-8 Manuscript under review for journal Geosci. Model Dev.

Discussion started: 24 January 2018

(c) Author(s) 2018. CC BY 4.0 License.

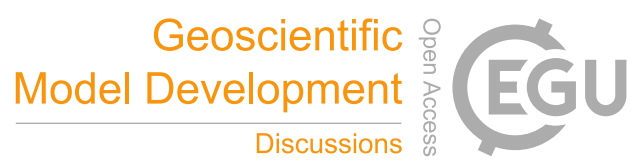

(c) (i)

(a)

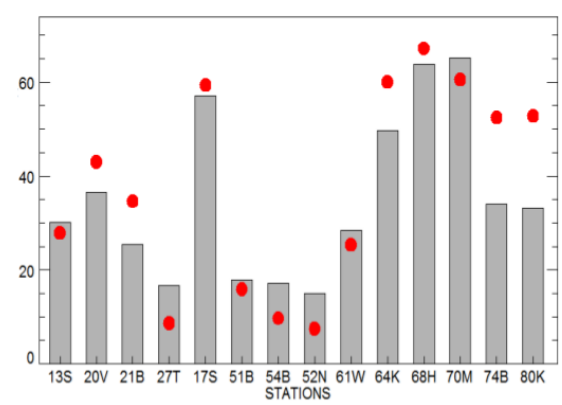

(c)

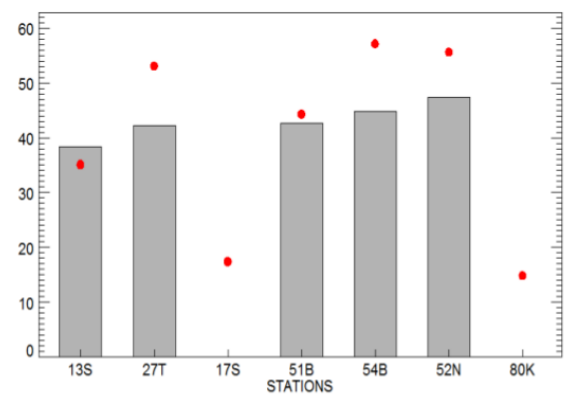

(e)

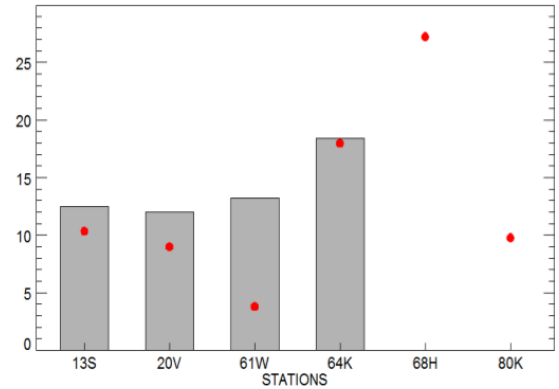

(b)

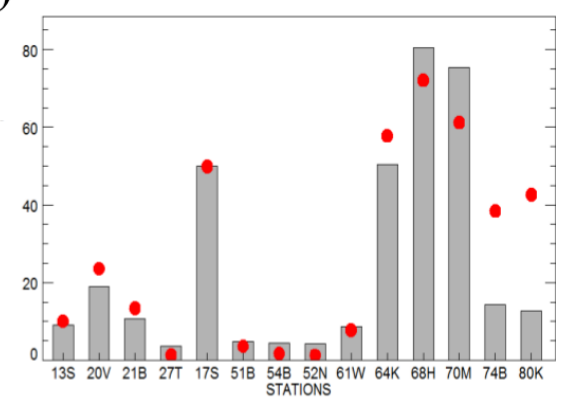

(d)

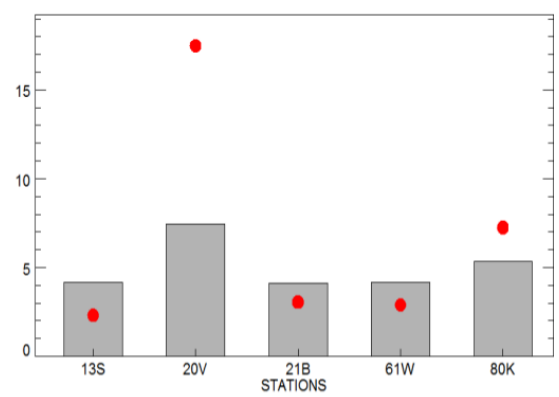

(f)

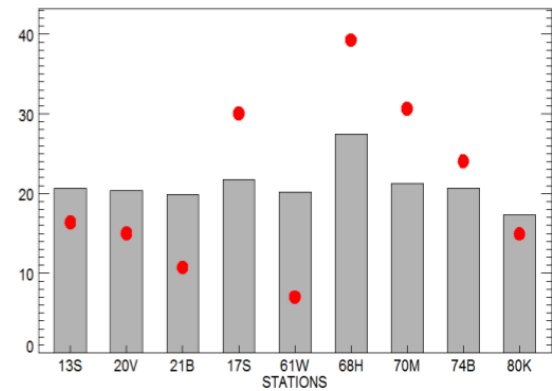

Figure 13. Bar plots comparing modelled and observed mean annual concentrations $\left(\mu \mathrm{g} \mathrm{m}^{-3}\right)$ for monitoring stations of the Hamburg AQ network: (a) $\mathrm{NO}_{2}$, (b) $\mathrm{NO}$, (c) $\mathrm{O}_{3}$ (d) $\mathrm{SO}_{2}$, (e) $\mathrm{PM}_{2.5}$, and (f) $\mathrm{PM}_{10}$. Observed values as grey filled bars, modelled values indicated as red circles. Observation data not shown for stations were data completeness was less than $75 \%$ during 2012 for the respective air pollutant (for $\mathrm{O}_{3}: 17 \mathrm{SM}$ and $80 \mathrm{KT}$, for $\mathrm{PM}_{2.5}: 68 \mathrm{HB}$ and $80 \mathrm{KT}$ ). 
Geosci. Model Dev. Discuss., https://doi.org/10.5194/gmd-2018-8

Manuscript under review for journal Geosci. Model Dev.

Discussion started: 24 January 2018

(c) Author(s) 2018. CC BY 4.0 License.

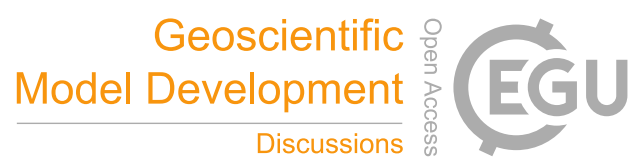

(c) (i)

(a)

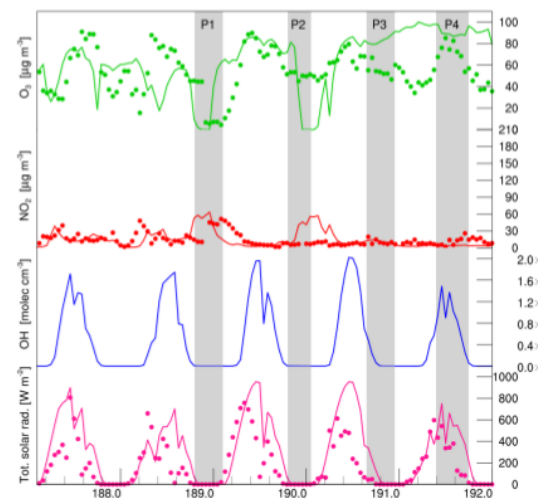

(b)

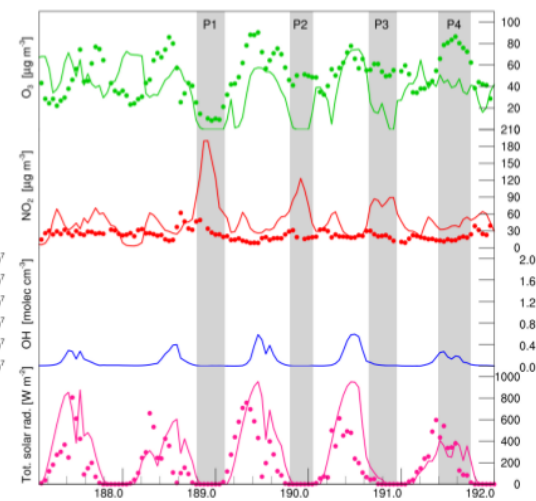

(c)

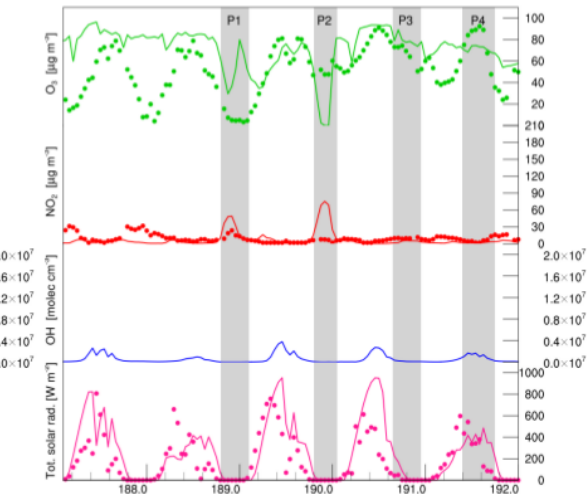

Figure 14. Ozone variation in summer 5-day episode (5-9 July, 2012): hourly concentrations of $\mathrm{O}_{3}\left(\mu \mathrm{g} \mathrm{m}^{-3}\right), \mathrm{NO}_{2}\left(\mu \mathrm{g} \mathrm{m}^{-3}\right)$, $\mathrm{OH}$ radical (molecule $\mathrm{cm}^{-3}$ ) and hourly total solar radiation $\left(\mathrm{W} \mathrm{m}^{-2}\right.$ ) at three stations in different parts of the Hamburg study domain: (a) station Blankenese (54BL) at the western border of the domain, (b) station Sternschanze (13ST) representative of inner-city urban background, and (c) station Tatenberg (27TA) at the south eastern part of Hamburg. Observations indicated by filled circles and model results by solid lines. Four short periods with ozone under predicted by the model at 13ST shown as grey shaded area, labelled with P1 - P4.

(a)

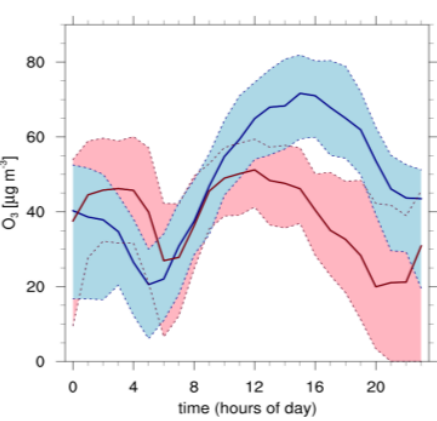

(c)

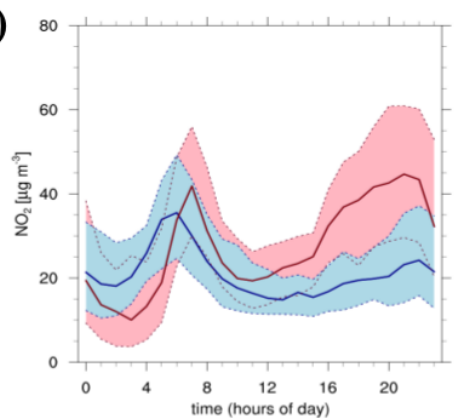

(b)

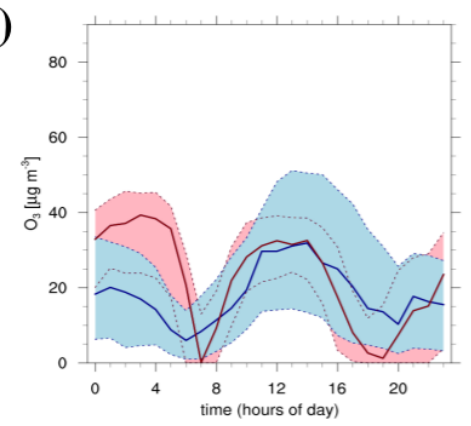

(d)

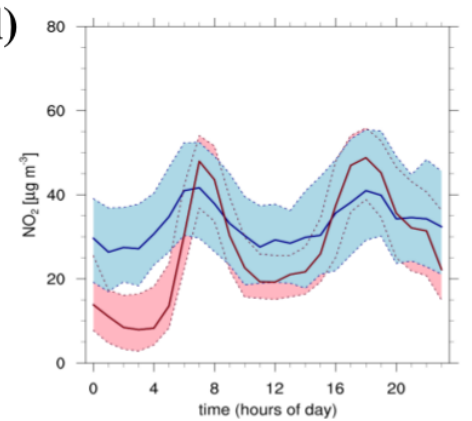

Figure 15. Diurnal cycle of $\mathrm{O}_{3}$ and $\mathrm{NO}_{2}$ concentrations $\left(\mu \mathrm{g} \mathrm{m}^{-3}\right)$ at station 13ST based on the hourly modelled and observed values: (a) summer $\mathrm{O}_{3}$, (b) autumn $\mathrm{O}_{3}$, (c) summer $\mathrm{NO}_{2}$, (d) autumn $\mathrm{NO}_{2}$. Modelled median shown as red line and observed median as blue line. Shaded area reflects the band width between the 25th percentile and the 75th percentile (model red-shaded; observation blue-shaded). 
Geosci. Model Dev. Discuss., https://doi.org/10.5194/gmd-2018-8

Manuscript under review for journal Geosci. Model Dev.

Discussion started: 24 January 2018

(c) Author(s) 2018. CC BY 4.0 License.

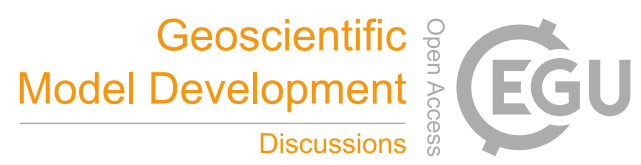

(c) (i)

(a)

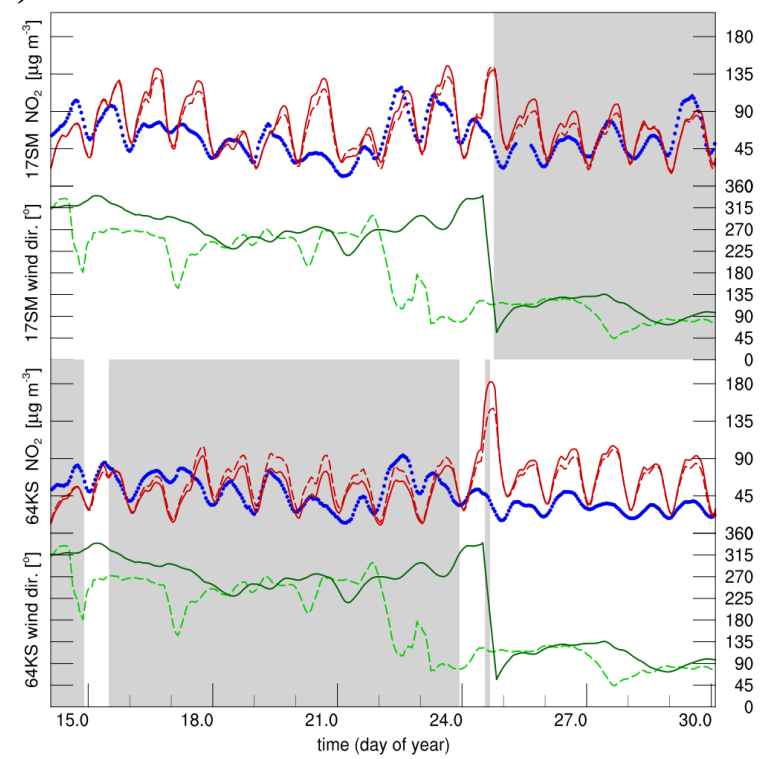

(b)

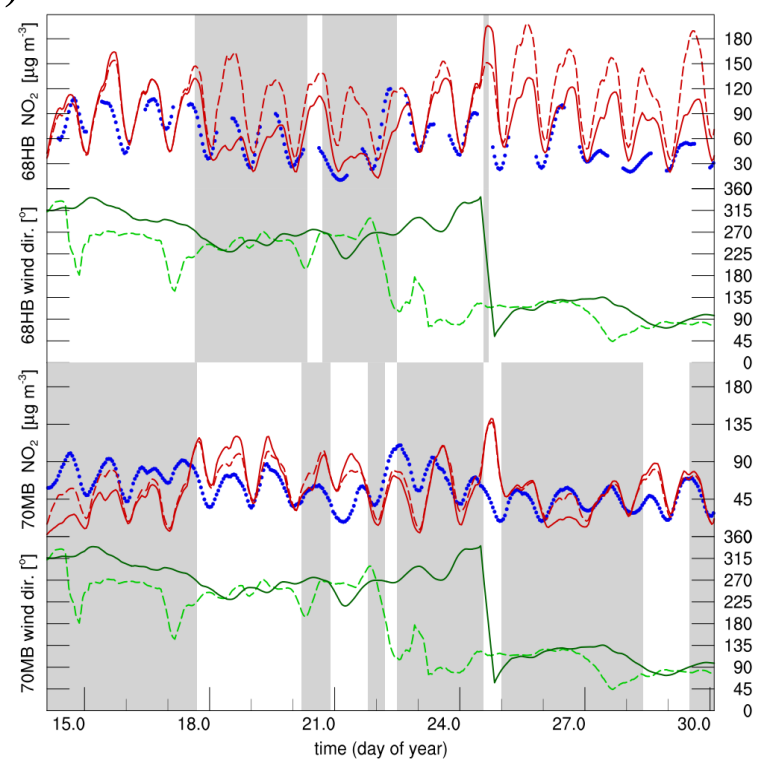

Figure 16. Traffic station comparison of modelled and observed $\mathrm{NO}_{2}$ concentration shown as 8-h running mean for a 16-day period in January (14-29 January 2012): (a) at stations 17SM (upper part) and 64KS (lower part), and (b) at stations 68HB (upper part) and 70MB (lower part). Results from a CityChem run with reference configuration (red solid line) versus a run with the simplified street canyon model (SSCM, red dashed line) activated; together with measured $\mathrm{NO}_{2}$ concentrations (blue dots). Modelled wind direction (dark green lines) in the panel below the concentrations together with the measured $10 \mathrm{~m}$ wind direction (light green dashes) at the weather mast is also shown. Grey-shaded areas indicate when the station was on the leeward side of the street canyon (excluding a sector with a street angle of $<30^{\circ}$ and $>150^{\circ}$; street angle defined as the angle between the street axis and the wind direction) based on the modelled wind direction. 
Geosci. Model Dev. Discuss., https://doi.org/10.5194/gmd-2018-8

Manuscript under review for journal Geosci. Model Dev.

Discussion started: 24 January 2018

(c) Author(s) 2018. CC BY 4.0 License.

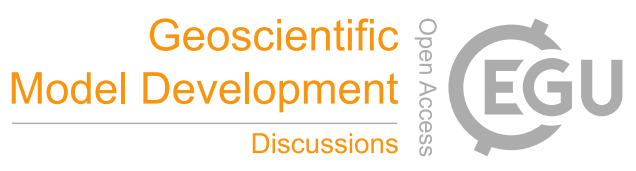

(c) (i)

Table 1. Numerical schemes provided in CityChem to solve the processes of the advection/-diffusion equation on the Eulerian 3-D grid. The model user can select from the options but preferably the recommended option should be used. Each of the atmospheric processes can be deactivated in the run script. It is also indicated which of the schemes are used in the operational EPISODE dispersion model.

\begin{tabular}{|c|c|c|c|}
\hline Process & Options & Usage & $\begin{array}{l}\text { Description, } \\
\text { reference }\end{array}$ \\
\hline \multirow[t]{3}{*}{$\begin{array}{l}\text { Vertical advection } \\
\text { and diffusion }\end{array}$} & $\begin{array}{l}\text { Combined upstream advection and explicit dif- } \\
\text { fusion scheme }\end{array}$ & $\begin{array}{l}\text { For test purposes only; } \\
\text { very time consuming }\end{array}$ & Slørdal et al. (2003) \\
\hline & $\begin{array}{l}\text { Vertical explicit diffusion scheme followed by } \\
\text { upstream advection scheme }\end{array}$ & $\begin{array}{l}\text { For test purposes only; } \\
\text { very time consuming }\end{array}$ & Slørdal et al. (2003) \\
\hline & $\begin{array}{l}\text { Vertical upstream advection and semi-implicit } \\
\text { Crank-Nicholson diffusion scheme }\end{array}$ & $\begin{array}{l}\text { Recommended. } \\
\text { Used in EPISODE }\end{array}$ & Byun et al. (1999) \\
\hline \multirow[t]{2}{*}{$\begin{array}{l}\text { Horizontal } \\
\text { 2-D advection }\end{array}$} & Positive definite 4 th degree Bott scheme & $\begin{array}{l}\text { Recommended. } \\
\text { Used in EPISODE }\end{array}$ & Bott (1989) \\
\hline & $\begin{array}{l}\text { Positive definite and monotone 4th degree Bott } \\
\text { scheme }\end{array}$ & For test purposes only & Bott $(1992,1993)$ \\
\hline $\begin{array}{l}\text { Horizontal } \\
\text { 2-D diffusion }\end{array}$ & Fully explicit forward Euler scheme & $\begin{array}{l}\text { Recommended. } \\
\text { Used in EPISODE }\end{array}$ & Smith (1985) \\
\hline \multirow[t]{3}{*}{ Chemical reactions } & $\begin{array}{l}\text { Photochemical steady state assumption for } \\
\mathrm{O}_{3} / \mathrm{NO} / \mathrm{NO}_{2}\end{array}$ & $\begin{array}{l}\text { For test purposes only. } \\
\text { Used in EPISODE }\end{array}$ & Slørdal et al. (2003) \\
\hline & $\begin{array}{l}\text { Photo-equilibrium of } \mathrm{O}_{3} / \mathrm{NO} / \mathrm{NO}_{2} \text { solved with } \\
\text { modified TWOSTEP algorithm }\end{array}$ & For test purposes only & Sect. S4, Suppl. \\
\hline & $\begin{array}{l}\text { "CC45" reaction scheme solved with modified } \\
\text { TWOSTEP algorithm }\end{array}$ & Recommended & Sect. S4, Suppl. \\
\hline
\end{tabular}

Table 2. Geometry of three generic street canyon types in CityChem. For street canyons of type "urban medium", $H_{s c}$ is taken as the mean value of "urban low" and "urban high".

\begin{tabular}{llrrr}
\hline TAPM land use class & Street canyon type & $\begin{array}{r}\text { Average building } \\
\text { height, } H_{s c}[\mathrm{~m}]\end{array}$ & $\begin{array}{r}\text { Street canyon } \\
\text { width }[\mathrm{m}]\end{array}$ & Building density \\
\hline 32 & Urban low & 6.6 & $2 W$ & Sparse-built area \\
33 & Urban medium & 12.3 & $2 W$ & Medium density area \\
34 and 35 & Urban high & 18.0 & $2 W$ & Dense-built area \\
\hline
\end{tabular}


Geosci. Model Dev. Discuss., https://doi.org/10.5194/gmd-2018-8

Manuscript under review for journal Geosci. Model Dev.

Discussion started: 24 January 2018

(c) Author(s) 2018. CC BY 4.0 License.

Table 3. Description of the pre-processing utilities for preparation of input files for a CityChem simulation.

\begin{tabular}{|c|c|c|c|}
\hline Utility & Purpose & Required input & $\begin{array}{l}\text { Produced input } \\
\text { for CityChem }\end{array}$ \\
\hline MCWIND & $\begin{array}{l}\text { MCWIND produces a diagnostic wind } \\
\text { field and other meteorological fields for } \\
\text { the defined model grid for each hour. } \\
\text { MCWIND adjusts a first guess wind } \\
\text { field to a given topography in such man- } \\
\text { ner that it becomes mass consistent. }\end{array}$ & $\begin{array}{l}\text { Meteorological observations from a } \\
\text { meteorological tower (temperature at } \\
\text { two heights, wind speed and direc- } \\
\text { tion, rel. humidity, precipitation, cloud } \\
\text { cover) and wind observations (at sur- } \\
\text { face) from at least one other meteoro- } \\
\text { logical station are required. }\end{array}$ & $\begin{array}{l}\text { Meteorological files in ASCII- } \\
\text { format, except of the file con- } \\
\text { taining the } u, v \text {, and } w \text { wind } \\
\text { components, which is in binary } \\
\text { EPISODE-format. }\end{array}$ \\
\hline BCONCC & $\begin{array}{l}\text { BCONCC produces 3-D boundary con- } \\
\text { ditions (BCON) files based on CMAQ } \\
\text { concentrations for a regional model do- } \\
\text { main (see https://www.epa.gov/cmaq/). }\end{array}$ & $\begin{array}{l}\text { Concentration output (CONC* files) } \\
\text { from the CMAQ model for a geograph- } \\
\text { ical region that includes the city model } \\
\text { domain. }\end{array}$ & $\begin{array}{l}\text { EPISODE-format binary files } \\
\text { containing hourly varying } 3-\mathrm{D} \\
\text { boundary concentrations for the } \\
\text { most relevant species. }\end{array}$ \\
\hline UECT & $\begin{array}{l}\text { UECT (Urban Emission Conversion } \\
\text { Tool) produces the various emission in- } \\
\text { put files for point sources, line sources } \\
\text { and area source categories. }\end{array}$ & $\begin{array}{l}\text { Emission data of geo-referenced yearly } \\
\text { emission totals for } \mathrm{NO}_{\mathrm{X}}, \mathrm{NMVOC}, \mathrm{CO} \text {, } \\
\mathrm{SO}_{2}, \mathrm{NH}_{3}, \mathrm{PM}_{2.5} \text { and } \mathrm{PM}_{10} \text {. }\end{array}$ & $\begin{array}{l}\text { Emission input files in ASCII- } \\
\text { format containing hourly varying } \\
\text { emission data based on defined } \\
\text { for each source. }\end{array}$ \\
\hline AERMAP & $\begin{array}{l}\text { AERMAP can process terrain data de- } \\
\text { rived from NASA's Shuttle Radar To- } \\
\text { pography Mission (SRTM; Rodriguez } \\
\text { et al., 2005). SRTM digital elevation } \\
\text { data is available at } 3 \text { arc-second reso- } \\
\text { lution. }\end{array}$ & $\begin{array}{l}\text { Digital Elevation Data SRTM3 for the } \\
\text { region of interest from the map of the } \\
\text { world can be downloaded at: } \\
\text { www.viewfinderpanoramas. } \\
\text { org/Coverage\%20map\% } \\
\text { 20viewfinderpanoramas_org3.htm. }\end{array}$ & $\begin{array}{l}\text { AERMAP produces a ter- } \\
\text { rain elevation output file } \\
\text { (AERMAP.REC) in ASCII- } \\
\text { format. The utility static } 4 \mathrm{cc} \\
\text { is then used to generate the } \\
\text { topography input file. }\end{array}$ \\
\hline TAPM4CC & $\begin{array}{l}\text { TAPM4CC creates } 2-\mathrm{D} \text { and } 3-\mathrm{D} \text { input } \\
\text { files for meteorology by reading the } \\
\text { TAPM outa-file and writing files for all } \\
\text { required meteorological variables. }\end{array}$ & $\begin{array}{l}\text { The TAPM built-in tool TAPM2OUTA } \\
\text { converts selected output files of TAPM } \\
\text { for a particular date range into a TAPM } \\
\text { outa-file, in ASCII format. }\end{array}$ & $\begin{array}{l}\text { Hourly varying meteorological 2- } \\
\mathrm{D} \text { and 3-D (24 vertical layers up } \\
\text { to } 3750 \mathrm{~m} \text { height) input files in } \\
\text { binary EPISODE-format. }\end{array}$ \\
\hline z0top4cc & $\begin{array}{l}\text { The tool z0top4cc reads TAPM land use } \\
\text { class values and writes input files for } \\
\text { land use, surface roughness and cloud } \\
\text { fraction. }\end{array}$ & $\begin{array}{l}\text { TAPM land use class information ex- } \\
\text { tracted with the TAPM Graphical User } \\
\text { Interface (GUI). }\end{array}$ & $\begin{array}{l}\text { Input files for land use, surface } \\
\text { roughness and cloud fraction in } \\
\text { ASCII-format. }\end{array}$ \\
\hline static $4 \mathrm{cc}$ & $\begin{array}{l}\text { The tool static } 4 \mathrm{cc} \text { can be used to write } \\
\text { input files for land use and surface } \\
\text { roughness if TAPM is not available. It } \\
\text { also produces the topography file based } \\
\text { on output from AERMAP. }\end{array}$ & $\begin{array}{l}\text { AERMAP.REC for topography output. } \\
\text { Constant values are used for land use } \\
\text { and surface roughness, which can be } \\
\text { changed in the source code of static } 4 \mathrm{cc} \text {. }\end{array}$ & $\begin{array}{l}\text { Input files for land use, sur- } \\
\text { face roughness and topography in } \\
\text { ASCII-format. }\end{array}$ \\
\hline
\end{tabular}


Geosci. Model Dev. Discuss., https://doi.org/10.5194/gmd-2018-8

Manuscript under review for journal Geosci. Model Dev.

Discussion started: 24 January 2018

(c) Author(s) 2018. CC BY 4.0 License.

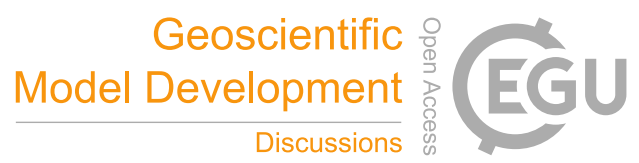

(c) (i)

Table 4. Test of point source dispersion of $\mathrm{SO}_{2}$ for different atmospheric stability conditions in flat terrain at wind speed $1 \mathrm{~m} \mathrm{~s}^{-1}$. Hourly concentration is given at the location where the maximum is found for the 5-day average within a radius of $1.5 \mathrm{~km}$ around the point source. Parameterisation of point source: exhaust gas temperature: $20^{\circ} \mathrm{C}$, exit velocity: $5 \mathrm{~m} \mathrm{~s}^{-1}$, stack radius: $0.5 \mathrm{~m}$ (circular opening).

\begin{tabular}{|c|c|c|c|c|}
\hline Parameter & stable & neutral & $\begin{array}{l}\text { slightly } \\
\text { unstable }\end{array}$ & $\begin{array}{l}\text { very } \\
\text { unstable }\end{array}$ \\
\hline $\begin{array}{l}\text { Temperature gradient } \\
\Delta T / \Delta z\left[\mathrm{~K} \mathrm{~m}^{-1}\right]\end{array}$ & 0.10 & -0.01 & -0.016 & -0.10 \\
\hline Emission rate $\left[\mathrm{g} \mathrm{s}^{-1}\right]$ & 1.0 & 1.0 & 1.0 & 1.0 \\
\hline Stack height $[\mathrm{m}]$ & 10 & 10 & 10 & 10 \\
\hline $\begin{array}{l}\text { Effective emission } \\
\text { height, } H_{e f f}[\mathrm{~m}]\end{array}$ & 47.4 & 40.5 & 38.8 & 32.4 \\
\hline $\begin{array}{l}\text { Distance of maximum } \\
\text { ground conc. }[\mathrm{m}]\end{array}$ & 670 & 320 & 240 & 180 \\
\hline $\begin{array}{l}\text { Hourly ground air conc. } \\
\text { at maximum }\left[\mu \mathrm{g} \mathrm{m}^{-3}\right]\end{array}$ & 0.7 & 79.8 & 85.3 & 112.7 \\
\hline
\end{tabular}


Geosci. Model Dev. Discuss., https://doi.org/10.5194/gmd-2018-8

Manuscript under review for journal Geosci. Model Dev.

Discussion started: 24 January 2018

(c) Author(s) 2018. CC BY 4.0 License.

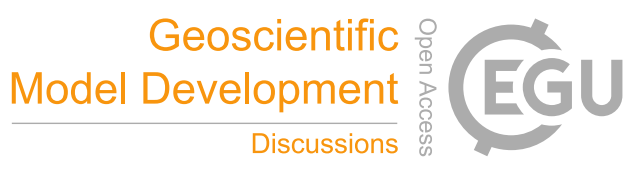

(c) (1)

Table 5. Emission sectors data for the simulation of air quality in Hamburg. Classification according to Selected Nomenclature for sources of Air Pollution (SNAP). The top heights of layer 1, 2, 3, and 4 are $17.5 \mathrm{~m}, 37.5 \mathrm{~m}, 62.5 \mathrm{~m}$, and $87.5 \mathrm{~m}$ above ground, respectively. Point source emission data for SNAP categories 01, 04, 05, and 09 were collected from the PRTR database (PRTR, 2017) and from the registry of emission data for point sources in Hamburg as reported under the German Federal Immission Control Act (BImSchV 11).

\begin{tabular}{|c|c|c|c|c|}
\hline SNAP & SNAP name & Source type & Vertical distribution & Emission data source and approach \\
\hline 01 & $\begin{array}{l}\text { Combustion in energy and transformation } \\
\text { industries }\end{array}$ & Point & Plume rise & $\begin{array}{l}\text { Bottom-up approach. Data set on European } \\
\text { stacks by Pregger and Friedrich (2009). }\end{array}$ \\
\hline 02 & $\begin{array}{l}\text { Non-industrial combustion plants (domestic } \\
\text { heating) }\end{array}$ & $\begin{array}{l}\text { Area } \\
\left(1 \times 1 \mathrm{~km}^{2}\right)\end{array}$ & $\begin{array}{l}70 \% \text { in layer } 1 ; \\
30 \% \text { in layer } 2\end{array}$ & $\begin{array}{l}\text { GRETA software (Schneider et al., 2016), } \\
\text { top-down with spatial and temporal disag- } \\
\text { gregation. }\end{array}$ \\
\hline 03 & Combustion in manufacturing industry & $\begin{array}{l}\text { Area } \\
\left(1 \times 1 \mathrm{~km}^{2}\right)\end{array}$ & $\begin{array}{l}70 \% \text { in layer } 1 \\
30 \% \text { in layer } 2\end{array}$ & $\begin{array}{l}\text { GRETA software (Schneider et al., 2016), } \\
\text { top-down with spatial and temporal disag- } \\
\text { gregation. }\end{array}$ \\
\hline 04 & Production processes & Point & Plume rise & $\begin{array}{l}\text { Bottom-up approach. Data set on European } \\
\text { stacks by Pregger and Friedrich (2009). }\end{array}$ \\
\hline 05 & $\begin{array}{l}\text { Extraction and distribution of fossil fuels } \\
\text { and geothermal energy }\end{array}$ & Point & Plume rise & $\begin{array}{l}\text { Bottom-up approach. Data set on European } \\
\text { stacks by Pregger and Friedrich (2009). }\end{array}$ \\
\hline 06 & Solvent and other product use & $\begin{array}{l}\text { Area } \\
\left(1 \times 1 \mathrm{~km}^{2}\right)\end{array}$ & $100 \%$ in layer 1 & $\begin{array}{l}\text { GRETA software (Schneider et al., 2016), } \\
\text { top-down with spatial and temporal disag- } \\
\text { gregation. }\end{array}$ \\
\hline 07 & Road transport & Line & At $0 \mathrm{~m}$ above ground & $\begin{array}{l}\text { Bottom-up method using emission factors } \\
\text { from HBEFA version } 3.1 \text { (UBA, 2010). }\end{array}$ \\
\hline 08 & Other mobile sources and machinery & $\begin{array}{l}\text { Area } \\
\left(1 \times 1 \mathrm{~km}^{2}\right)\end{array}$ & $\begin{array}{l}\text { Shipping: } 25 \% \text { in each } \\
\text { layer } 1-4 . \\
\text { Other: same as for SNAP } \\
\text { cat. } 10 .\end{array}$ & $\begin{array}{l}\text { Shipping: Aulinger et al. (2016). } \\
\text { Other: GRETA software (Schneider et al., } \\
\text { 2016), top-down with spatial and temporal } \\
\text { disaggregation. }\end{array}$ \\
\hline 09 & $\begin{array}{l}\text { Waste collection, treatment and } \\
\text { disposal activities }\end{array}$ & Point & Plume rise & $\begin{array}{l}\text { Bottom-up approach. Data set on European } \\
\text { stacks by Pregger and Friedrich (2009). }\end{array}$ \\
\hline 10 & Agriculture and farming & $\begin{array}{l}\text { Area } \\
\left(1 \times 1 \mathrm{~km}^{2}\right)\end{array}$ & $\begin{array}{l}70 \% \text { in layer } 1 \\
30 \% \text { in layer } 2\end{array}$ & $\begin{array}{l}\text { GRETA software (Schneider et al., 2016), } \\
\text { top-down with spatial and temporal disag- } \\
\text { gregation. }\end{array}$ \\
\hline
\end{tabular}


Geosci. Model Dev. Discuss., https://doi.org/10.5194/gmd-2018-8

Manuscript under review for journal Geosci. Model Dev.

Discussion started: 24 January 2018

(c) Author(s) 2018. CC BY 4.0 License.

Table 6. Model performance statistics of CityChem for $\mathrm{O}_{3}$ based on daily maximum of the 8-h running mean concentration at all stations with sufficient data availability in 2012.

\begin{tabular}{lcccccccc}
\hline Station code & $\begin{array}{c}\bar{O} \\
{\left[\mu \mathrm{g} \mathrm{m}^{-3}\right]}\end{array}$ & $\begin{array}{c}\bar{M} \\
{\left[\mu \mathrm{g} \mathrm{m}^{-3}\right]}\end{array}$ & $\begin{array}{c}\mathrm{STD}_{O} \\
{\left[\mu \mathrm{g} \mathrm{m}^{-3}\right]}\end{array}$ & $\begin{array}{c}\mathrm{STD}_{M} \\
{\left[\mu \mathrm{g} \mathrm{m}^{-3}\right]}\end{array}$ & $\begin{array}{r}\mathrm{NMB} \\
{[\%]}\end{array}$ & $\begin{array}{r}\text { Corr } \\
{[-]}\end{array}$ & $\begin{array}{c}\text { RMSE } \\
{\left[\mu \mathrm{g} \mathrm{m}^{-3}\right]}\end{array}$ & $\begin{array}{r}\text { IOA } \\
{[-]}\end{array}$ \\
\hline 13ST & 48.32 & 55.53 & 25.22 & 21.76 & -12.98 & 0.40 & 26.80 & 0.63 \\
27TA & 55.90 & 63.60 & 23.85 & 22.58 & 7.98 & 0.53 & 23.12 & 0.70 \\
$51 \mathrm{BF}$ & 61.00 & 57.36 & 25.37 & 24.18 & -5.97 & 0.51 & 24.75 & 0.71 \\
$54 \mathrm{BL}$ & 61.09 & 69.03 & 24.90 & 23.80 & 13.01 & 0.44 & 26.90 & 0.63 \\
$52 \mathrm{NG}$ & 65.17 & 66.91 & 25.14 & 24.13 & 2.68 & 0.46 & 25.57 & 0.66 \\
\hline
\end{tabular}

Table 7. Model performance statistics of CityChem for $\mathrm{NO}_{2}$ based on hourly concentration at all stations with sufficient data availability in 2012.

\begin{tabular}{lcrrrrrrr}
\hline Station code & $\begin{array}{c}\bar{O} \\
{\left[\mu \mathrm{g} \mathrm{m}^{-3}\right]}\end{array}$ & $\begin{array}{c}\bar{M} \\
{\left[\mu \mathrm{g} \mathrm{m}^{-3}\right]}\end{array}$ & $\begin{array}{c}\mathrm{STD}_{O} \\
{\left[\mu \mathrm{g} \mathrm{m}^{-3}\right]}\end{array}$ & $\begin{array}{c}\mathrm{STD}_{M} \\
{\left[\mu \mathrm{g} \mathrm{m}^{-3}\right]}\end{array}$ & $\begin{array}{r}\mathrm{NMB} \\
{[\%]}\end{array}$ & $\begin{array}{r}\text { Corr } \\
{[-]}\end{array}$ & $\begin{array}{c}\text { RMSE } \\
{\left[\mu \mathrm{g} \mathrm{m}^{-3}\right]}\end{array}$ & $\begin{array}{r}\text { IOA } \\
{[-]}\end{array}$ \\
\hline $13 \mathrm{ST}$ & 30.07 & 27.92 & 15.72 & 19.30 & -7.15 & 0.22 & 22.14 & 0.53 \\
$20 \mathrm{VE}$ & 36.47 & 43.01 & 17.39 & 27.66 & 17.94 & 0.22 & 29.92 & 0.47 \\
$21 \mathrm{BI}$ & 25.40 & 34.67 & 15.13 & 17.90 & 36.50 & 0.22 & 22.75 & 0.49 \\
$27 \mathrm{TA}$ & 16.70 & 8.67 & 11.34 & 10.94 & -48.10 & 0.23 & 15.99 & 0.51 \\
$17 \mathrm{SM}$ & 57.02 & 59.38 & 27.63 & 31.29 & 4.14 & 0.32 & 34.48 & 0.58 \\
$51 \mathrm{BF}$ & 17.83 & 15.88 & 12.06 & 14.03 & -10.94 & 0.24 & 16.30 & 0.53 \\
$54 \mathrm{BL}$ & 17.16 & 9.74 & 12.65 & 9.93 & -43.26 & 0.24 & 15.94 & 0.51 \\
$52 \mathrm{NG}$ & 14.92 & 7.46 & 11.67 & 9.85 & -50.01 & 0.22 & 15.40 & 0.51 \\
$61 \mathrm{WB}$ & 28.44 & 25.37 & 15.20 & 17.75 & -10.79 & 0.24 & 20.59 & 0.55 \\
$64 \mathrm{KS}$ & 49.61 & 60.09 & 24.03 & 33.00 & 21.13 & 0.29 & 36.19 & 0.54 \\
$68 \mathrm{HB}$ & 63.77 & 67.22 & 35.99 & 36.75 & 5.41 & 0.34 & 42.04 & 0.60 \\
$70 \mathrm{MB}$ & 65.12 & 60.59 & 27.29 & 32.83 & -6.96 & 0.31 & 35.87 & 0.58 \\
$74 \mathrm{BT}$ & 34.08 & 52.49 & 16.98 & 30.14 & 54.03 & 0.24 & 35.94 & 0.44 \\
$80 \mathrm{KT}$ & 33.13 & 52.49 & 16.98 & 30.14 & 54.03 & 0.24 & 35.94 & 0.44 \\
& & & & & & & & \\
\hline
\end{tabular}


Geosci. Model Dev. Discuss., https://doi.org/10.5194/gmd-2018-8 Manuscript under review for journal Geosci. Model Dev.

Discussion started: 24 January 2018

(c) Author(s) 2018. CC BY 4.0 License.

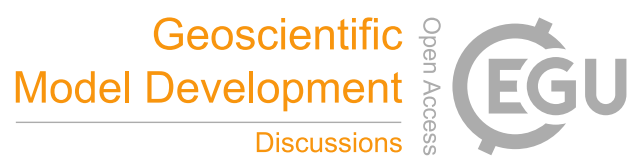

(c) (i)

Table 8. Model performance statistics of CityChem for $\mathrm{PM}_{10}$ based on daily mean concentration at all stations with sufficient data availability in 2012.

\begin{tabular}{|c|c|c|c|c|c|c|c|c|}
\hline Station code & $\begin{array}{c}\bar{O} \\
{\left[\mu \mathrm{g} \mathrm{m}^{-3}\right]}\end{array}$ & $\begin{array}{c}\bar{M} \\
{\left[\mu \mathrm{g} \mathrm{m}^{-3}\right]}\end{array}$ & $\begin{array}{c}\operatorname{STD}_{O} \\
{\left[\mu \mathrm{g} \mathrm{m}^{-3}\right]}\end{array}$ & $\begin{array}{c}\mathrm{STD}_{M} \\
{\left[\mu \mathrm{g} \mathrm{m}^{-3}\right]}\end{array}$ & $\begin{array}{r}\mathrm{NMB} \\
{[\%]}\end{array}$ & $\begin{array}{r}\text { Corr } \\
{[-]}\end{array}$ & $\begin{array}{l}\text { RMSE } \\
{\left[\mu \mathrm{g} \mathrm{m}^{-3}\right]}\end{array}$ & $\begin{array}{r}\text { IOA } \\
{[-]}\end{array}$ \\
\hline $13 \mathrm{ST}$ & 20.65 & 16.38 & 11.11 & 8.15 & -20.68 & 0.12 & 13.67 & 0.43 \\
\hline 20VE & 20.36 & 15.00 & 9.74 & 13.40 & -26.36 & 0.23 & 15.63 & 0.48 \\
\hline $21 \mathrm{BI}$ & 19.85 & 10.72 & 10.11 & 6.41 & -45.99 & 0.13 & 14.46 & 0.45 \\
\hline $17 \mathrm{SM}$ & 21.78 & 30.04 & 11.60 & 16.73 & 37.93 & 0.06 & 21.39 & 0.32 \\
\hline $61 \mathrm{WB}$ & 20.14 & 7.00 & 9.71 & 4.38 & -65.23 & 0.28 & 16.19 & 0.44 \\
\hline $68 \mathrm{HB}$ & 27.49 & 39.27 & 11.03 & 18.93 & 42.86 & 0.23 & 22.90 & 0.40 \\
\hline $70 \mathrm{MB}$ & 21.29 & 30.63 & 10.37 & 15.42 & 43.87 & -0.02 & 20.94 & 0.32 \\
\hline $74 \mathrm{BT}$ & 20.66 & 24.03 & 9.81 & 12.91 & 16.33 & 0.03 & 16.33 & 0.35 \\
\hline $80 \mathrm{KT}$ & 17.33 & 14.94 & 9.05 & 10.25 & -13.80 & 0.18 & 12.49 & 0.50 \\
\hline
\end{tabular}

